UNIVERSIDADE DE SÃO PAULO

INSTITUTO DE FÍSICA

INSTITUTO DE QUÍMICA

INSTITUTO DE BIOCIÊNCIAS

FACULDADE DE EDUCAÇÃO

\title{
Desenvolvimento de um ambiente virtual para estudo sobre representação estrutural em Química
}

Jackson Gois da Silva

Orientador: Prof. Dr. Marcelo Giordan

Dissertação de mestrado

apresentada ao Instituto de Física, ao Instituto de Química, ao Instituto de Biociências e à Faculdade de Educação da Universidade de São Paulo, como parte dos requisitos para a obtenção do título de Mestre em Ensino de Ciências - modalidade Química. 
FICHA CATALOGRÁFICA

Preparada pelo Serviço de Biblioteca e Informação do Instituto de Física da Universidade de São Paulo

Silva, Jackson Gois da

Desenvolvimento de um ambiente virtual para

estudo sobre a representação estrutural em química

- São Paulo 2007.

Dissertação (Mestrado) - Universidade de São Paulo. Faculdade de Educação. Departamento de Metodologia do Ensino e Educação Comparada

Orientador: Prof Marcelo Giordan dos Santos

Área de Concentração: Ensino de Ciências

Unitermos: 1. Química - Estudo e ensino; 2. Tecnologia educacional; 3. Ensino médio; 4. Ensino por computador. 


\section{Agradecimentos}

A Deus pela vida.

A minha esposa Eliane pelo Amor.

Aos meus pais, pelo apoio desde os primeiros anos de vida e desde os primeiros passos rumo ao conhecimento.

Ao Marcelo Giordan, pelas oportunidades ímpares de contato com o conhecimento, e pelas férteis discussões.

Aos colegas do Programa Interunidades em Ensino de Ciências da USP, pela amizade.

Aos colegas do LAPEQ - FEUSP, Adriana, Luciana, Lucilene, Manuela, Paulo, Waldmir, Claudinei, William, João, Lílian, Agnaldo, Sílvia e Márcia, pelos momentos inesquecíveis que passamos juntos.

A todos os que contribuíram de forma direta ou indireta para a realização deste trabalho. 
SUMÁRIO

\begin{tabular}{|c|c|}
\hline Resumo & 05 \\
\hline Abstract & 06 \\
\hline 1 - Introdução & 07 \\
\hline 1.1 - Apresentação & 07 \\
\hline 1.2 - O ensino de química e a sociedade & 09 \\
\hline $\begin{array}{l}1.3 \text { - Uso da capacidade de processamento dos computadores com fins } \\
\text { educacionais }\end{array}$ & 16 \\
\hline 1.4 - TIC's e os problemas da educação & 19 \\
\hline 1.5 - Possibilidades de uso de TIC's na educação na atualidade & 23 \\
\hline 1.6 - Representação estrutural em química & 27 \\
\hline $\begin{array}{l}1.6 .1 \text { - As dimensões do conhecimento químico e suas } \\
\text { representações }\end{array}$ & 29 \\
\hline $\begin{array}{l}\text { 1.6.2 - As representações químicas e as tecnologias da informação } \\
\text { e comunicação. }\end{array}$ & 32 \\
\hline 1.6.3 - Tridimensionalidade e representações computacionais & 34 \\
\hline $\begin{array}{l}\text { 1.6.4 - Objetos moleculares computacionais: visualizações, } \\
\text { animações e simulações }\end{array}$ & 35 \\
\hline $1.7-$ Ambientes virtuais de ensino & 47 \\
\hline 1.7.1 - Histórico dos ambientes virtuais para o Ensino de Química & 51 \\
\hline 1.7.2 - Considerações sobre os dados da revisão bibliográfica & 71 \\
\hline 2 - Referenciais teóricos & 74 \\
\hline 2.1 - Conhecimento e mediação & 74 \\
\hline $2.2-$ Teoria dos Signos & 76 \\
\hline 2.2 .1 - Peirce: uma breve biografia & 77 \\
\hline 2.2.2 - O que é semiótica & 78 \\
\hline 2.2.3 - A tríade signo, objeto e interpretante & 79 \\
\hline 2.2.4 - As dimensões do conhecimento químico e os signos & 84 \\
\hline $\begin{array}{l}\text { 2.2.5 - Os signos e as representações químicas computacionais: o } \\
\text { ensino de química }\end{array}$ & 91 \\
\hline $2.2 .6-$ Síntese & 93 \\
\hline $3-$ Metodologia & 97 \\
\hline 3.1 - Construtor de Objetos Moleculares & 97 \\
\hline 3.1.1 - Interfaces com o usuário & 105 \\
\hline 3.2 - Captura de vídeo digital no ensino & 108 \\
\hline 3.2.1 - Captura sincronizada de vídeo & 111 \\
\hline 3.2.2 - Funcionamento do sistema & 114 \\
\hline 3.2.3 - Instalação do sistema & 116 \\
\hline 3.2.4 - Como assistir os vídeos resultantes & 117 \\
\hline 3.3 - Grupo-foco dos testes do ambiente virtual & 118 \\
\hline $3.4-$ Questionário & 119 \\
\hline 3.5 - Entrevista & 119 \\
\hline 4 - Dados e Discussão & 121 \\
\hline
\end{tabular}




\begin{tabular}{|l|c|}
\hline 4.1 - Questionário & 121 \\
\hline 4.2 - Entrevista e captura de vídeo & 135 \\
\hline $\begin{array}{l}\text { 4.2.1 - Sobre o trabalho em dupla utilizando o ambiente virtual } \\
\text { moleculares }\end{array}$ & 136 \\
\hline $\begin{array}{l}\text { 4.2.3 - Sobre o ambiente privilegiar o trabalho manual de montagem } \\
\text { de objetos moleculares }\end{array}$ & 139 \\
\hline 4.2.4 - Usabilidade em situações de ensino & 144 \\
\hline 5 - Considerações Finais & 147 \\
\hline 6 - Referências Bibliográficas & 148 \\
\hline Anexos & 152 \\
\hline Anexo 1 - O módulo de ensino & 164 \\
\hline Anexo 2 - O questionário respondido pelos estudantes & 164 \\
\hline
\end{tabular}




\section{Resumo}

Neste trabalho descrevemos as etapas de desenvolvimento do aplicativo computacional Construtor, a partir do qual estudantes de Ensino Médio podem construir objetos moleculares virtuais tridimensionais a partir unicamente da fórmula estrutural condensada de espécies químicas. Este aplicativo computacional foi adaptado em uma seqüência de ensino acessível pela internet através de navegadores hipertexto, o que resultou em um ambiente virtual de ensino de química. Também neste trabalho descrevemos a avaliação do uso do ambiente virtual descrito. Esta avaliação de uso foi feita por intermédio de dados obtidos com um sistema de captura sincronizada de vídeo, através do qual é possível gravar em arquivos de vídeo, de forma simultânea, a tela em uso pelo estudante e suas ações diante do computador, sendo os arquivos gravados no próprio computador em uso pelo estudante. Desta forma foi possível minimizar a introdução de equipamentos estranhos à aula durante o teste de usabilidade do sistema. Iniciamos nossa discussão a partir do conceito comumente aceito sobre o conhecimento químico ser composto por três dimensões, fazemos uma breve revisão sobre representações químicas, seus aspectos espaciais, a utilização de tecnologias da informação e comunicação e, mais especificamente, o uso de animações e simulações em ambientes de ensino de química, assim como uma revisão da bibliografia sobre os ambientes virtuais de ensino de química a partir de 1994. Neste trabalho, também fazemos uma discussão sobre a contribuição da teoria semiótica de Charles Sanders Peirce, com o objetivo de trazer uma compreensão mais aprofundada a respeito dos processos de significação de representações químicas, dos níveis macroscópico, submicroscópico e simbólico, na sala de aula. 


\section{Abstract}

In this work we describe the steps of the development of the software Construtor. With this computational program, High School students can build three-dimensional virtual molecular objects from the condensed structural formulas of chemical species. This computational program was adapted in a learning activity accessible through the internet with hypertext browsers, what resulted in a chemistry learning virtual environment. Also in this work we describe the use evaluation of the virtual environment described. We evaluated the use of this virtual environment from the data obtained with a video synchronized capture system, in witch it is possible to record in video files, simultaneously, the screen in use bye the students and their actions before the computer, in such a way the files are recorded in the same computer in use bye the student. Thus it was possible minimize the introduction of foreigner-class equipments during the usability test. We initiate our discussion from the concept about the chemical knowledge being composed by three dimensions, following a brief revision about chemical representations, its spatial aspects, the utilization of information and communication technologies and, more specifically, the use of animations and simulations in chemical teaching learning environments, as well as a revision about chemistry learning virtual environments from 1994. In this work we also discuss about thee contribution of the Semiotics theory of Charles Sanders Peirce, objecting to bring a deeper comprehension about the meaning processes of chemical representations, on the macroscopic, submicroscopic and symbolic levels, in classrooms. 


\section{1 - Apresentação}

Em minha atuação profissional como professor de Ensino Médio de Química, percebi claramente a dificuldade que os estudantes enfrentam quando são colocados diante das simbologias próprias desta disciplina. Estas dificuldades aparecem quando os estudantes realizam atividades em que este tipo de simbologia está presente de forma grafada ou falada, quando os mesmos são emissores ou receptores da mensagem, para entender o significado das simbologias e quando é necessário utilizá-las apropriadamente. Também durante minha atuação, percebi claramente o apreço dos estudantes por atividades que envolvem a utilização de tecnologias de informação e comunicação. Estas tecnologias têm forte apelo entre adolescentes provavelmente devido às possibilidades de interação em forma de áudio e vídeo oferecidas na atualidade, as quais têm sido preferidas como forma de interação com o mundo que os cerca [LÉVY, 1998].

Durante o curso de graduação em Bacharelado e Licenciatura em Química tive a oportunidade de adquirir conhecimentos de uso de computadores e de linguagens de programação ao cursar disciplinas de graduação como parte dos requisitos para a conclusão do Ensino Superior. Ainda na graduação pude aprofundar meus conhecimentos a respeito de sistemas operacionais e linguagens de programação através da participação como monitor em disciplinas de graduação, como Introdução a Computação para Ciências Exatas (MAC115), e também como monitor das salas do programa pró-aluno ${ }^{1}$ da USP. Ainda na graduação participei da implantação e manutenção das páginas hipertexto institucionais da USP através de estágio realizado no programa USPonline ${ }^{2}$ no ano 1996. Quando iniciei meu trabalho como docente já possuía conhecimentos sobre a produção de ambientes virtuais em formato hipertexto, de forma que, após algum tempo trabalhando em sala de aula, senti o desejo de produzir material didático virtual para o Ensino de Química.

1 http://www.pro-aluno.usp.br. Acessado em 12/10/2007.

2 http://www.ccs.usp.br/divisoes/inf_online/usponline.htm. Acessado em 12/10/2007 
Pelo fato de ter formação na área de informática, procurei trabalhar com minhas turmas de ensino médio de forma a colocar diante dos estudantes as possibilidades de visualização e manuseio que as tecnologias computacionais oferecem atualmente para o aprendizado da química. Antes da conclusão de um mestrado em modelagem molecular bioquímica [GOIS, 2004], onde adquiri conhecimentos sobre softwares de mecânica e dinâmica molecular, conheci o Laboratório de Pesquisa em Ensino de Química e Tecnologias Educacionais $\left(\right.$ LAPEQ $\left.^{1}\right)$ da Faculdade de Educação da USP $\left(F E U S P{ }^{2}\right)$, onde iniciei este trabalho de produção de um ambiente para estudo sobre visualização molecular.

A partir da dificuldade que estudantes iniciantes em química sentem quando são colocados diante de conceitos sobre a natureza particulada da matéria, e também do domínio e disponibilidade de TIC's, me dispus a criar, sob a orientação do Professor Marcelo Giordan, um ambiente virtual para o estudo do efeito que objetos moleculares tridimensionais podem ter no aprendizado de importantes conceitos da química.

Neste trabalho, tenho como intenção descrever as etapas de desenvolvimento de um ambiente virtual para alunos de Ensino Médio, onde o estudante possa se familiarizar com formas de representação próprias da Química, veiculadas por meio do uso de computadores, as quais enfatizam importantes características da natureza particulada da matéria. Também descreverei a avaliação do uso deste ambiente virtual por intermédio de dados obtidos com um novo sistema de registro da situação de uso de ambientes virtuais.

No capítulo introdutório apresento uma discussão a respeito da utilização de recursos computacionais no ensino, em especial no Ensino de Química, bem como uma revisão bibliográfica sobre ambientes virtuais de Ensino de Química disponíveis na literatura consultada. Ainda neste capítulo apresento uma discussão sobre um importante conceito de representação estrutural em Química, no âmbito das três dimensões do conhecimento

1 http://www.lapeq.fe.usp.br. Acessado em 12/10/2007.

2 http://www.fe.usp.br. Acessado em 12/10/2007. 
químico, ou seja, macroscópica, submicroscópica e simbólica, bem como a contribuição computacional na representação destas estruturas.

No segundo capítulo apresento os referenciais teóricos que serão utilizados na discussão dos dados obtidos neste trabalho, principalmente a concepção de signo de Charles Sanders Peirce, com uma visão aplicada ao Ensino da Química.

No terceiro capítulo apresento a metodologia utilizada no desenvolvimento do ambiente virtual e suas ferramentas, bem como a metodologia de obtenção dos dados que serão apresentados e discutidos.

No quarto capítulo apresento os dados obtidos e a discussão baseada no referencial teórico apresentado, e no quinto e último capítulo apresento as considerações finais sobre o trabalho.

\section{2 - O Ensino de Química e a Sociedade}

\footnotetext{
"Após 500 anos em que a leitura e a escrita verbal reduziram a comunicação pictórica a mero pano de fundo, o último terço de século testemunhou as imagens se tornarem novamente o principal meio de leitura e aprendizado.” [HABRAKEN, 1996].
}

Grande parte das bases teóricas e práticas da química como ciência foram lançadas quando o conhecimento humano na área de ciências exatas, como um todo, era dominado pela matemática. A Química evoluiu de um conhecimento profundamente baseado em linguagem algébrica e verbal para uma linguagem pictórica internacional, onde a percepção sobre o universo de partículas atômicas, moleculares e supramoleculares depende de memória visual, imaginação visual e processamento mental de informações visuais [HABRAKEN, 1996].

Estas informações visuais são referenciadas na realidade sensível através dos sentidos humanos. Na química supramolecular, por exemplo, o desenvolvimento de máquinas moleculares é inspirado em fenômenos estéticos, através de certas imagens que se referem simultaneamente a moléculas e objetos comuns (Figura 1), o que simbolicamente cria uma ponte entre o mundo das partículas de escala nanoscópica e o dos objetos cotidianos [SCHUMMER, 2006]. 
(a)

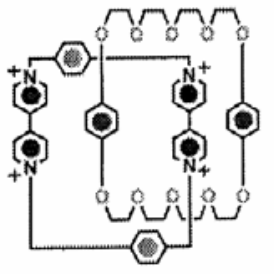

Fórmula Estrutural

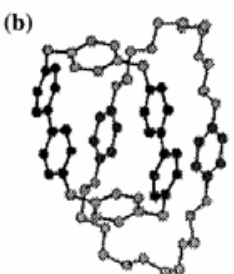

Estrutura Molecular (Raio-X)

(c)

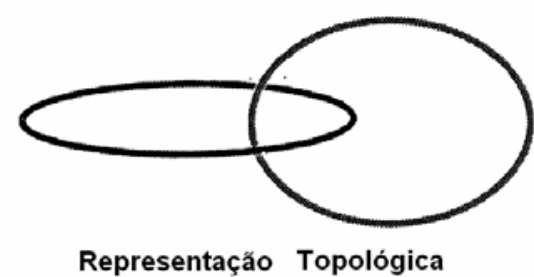

Figura 1. A figura representa a fórmula estrutural (a), a estrutura molecular (b) e a representação topológica (c) de uma molécula que se parece com um objeto comum, conhecida como catenana [SCHUMMER, 2006].

Esta capacidade de pensar em termos de partículas revelou parte importante da economia da matéria, o que impulsionou fortemente 0 conhecimento humano a respeito da constituição, tanto de materiais importantes para sua sobrevivência, quanto de sua própria maquinaria biológica.

Nos últimos anos, cientistas ligados a atividades acadêmicas e industriais têm criado e validado novas ferramentas de investigação através da engenharia de software, as quais integram as ciências que se beneficiam das visualizações moleculares, como a química, a bioquímica e a biologia molecular, com as tecnologias de hardware e software disponíveis na atualidade [FLETCHER, 1980; FRENKEL, 1990].

Com isso as tecnologias da informação e comunicação são parte integrante do ambiente de pesquisa moderno. A despeito disso os currículos tradicionais de química se tornaram alienados da pesquisa moderna em química, da tecnologia e, o mais importante, da sociedade, em suas demandas e questionamentos [DE VOS et al., 1994]. Este isolamento intencional ou acidental dos currículos escolares pode estar diretamente relacionado com a crescente diminuição proporcional na procura de cursos superiores da área de 
química em nível mundial nas últimas três décadas [LOWE, 1968; HAMMOND, 1977; SMITHERS, 1989].

\begin{tabular}{|c|c|c|c|}
\hline Ano & Vestibulandos SP* & $\begin{array}{c}\text { Vestibulandos } \\
\text { Química USP-SP** }\end{array}$ & $\begin{array}{c}\text { Relação } \\
\text { Vestibulandos } \\
\text { SP/QUIM }\end{array}$ \\
\hline 1995 & 865049 & 335 & 2582,2 \\
\hline 1996 & 783189 & 314 & 2494,2 \\
\hline 1997 & 794213 & 378 & 2101,1 \\
\hline 1998 & 807103 & 393 & 2053,7 \\
\hline 1999 & 905315 & 508 & 1782,1 \\
\hline 2000 & 1146599 & 663 & 1729,4 \\
\hline 2001 & 1074623 & 618 & 1738,9 \\
\hline 2002 & 1283439 & 641 & 2002,2 \\
\hline 2003 & 1225064 & 696 & 1760,1 \\
\hline 2004 & 1328237 & 670 & 1982,4 \\
\hline 2005 & 1318999 & 694 & 1900,6 \\
\hline
\end{tabular}

${ }^{*}$ Fonte: INEP

** Fonte: FUVEST

Tabela 1. Esta tabela mostra a diminuição relativa na procura de um dos cursos de bacharelado e licenciatura em Química da Universidade de São Paulo. Na segunda coluna da tabela temos o número total de inscritos em vestibulares no estado de São Paulo, e na terceira coluna temos o número de inscritos no curso de bacharelado e licenciatura em Química da USP Campus São Paulo. A quarta coluna é o resultado da divisão da segunda coluna pela terceira coluna.

$\mathrm{Na}$ Tabela 1 temos dados que exemplificam a diminuição relativa na procura de cursos de Química. As colunas de 1 a 3 da tabela mostram respectivamente o ano, o número total de inscritos em vestibulares no estado de São Paulo, e o número de inscritos no vestibular da FUVEST para ingresso no curso de Bacharelado e Licenciatura em Química da USP Campus São Paulo. A quarta coluna é o resultado da divisão da segunda coluna pela terceira coluna, o que resulta em um número que indica a procura relativa dos candidatos do estado de São Paulo por um curso de Química de uma grande e conhecida universidade estadual. Se a segunda e a terceira colunas forem analisadas de forma isolada será verificada uma tendência de aumento na 
procura dos vestibulandos tanto pelo vestibular de uma forma geral quanto pelo curso de Química da USP Campus São Paulo. No entanto, se as colunas forem analisadas de forma comparativa, através de uma divisão, por exemplo, será verificado que a procura relativa dos candidatos pelo curso está diminuindo. Este número tem uma tendência clara de queda na década analisada, e segue uma tendência mundial [HABRAKEN, 1996].

As tecnologias da comunicação e informação, nas suas várias formas de utilização diária como telefones celulares, tocadores MP3, relógios e calculadoras, já estão massivamente presentes na sociedade brasileira e, especificamente, na sala de aula. Dados recentes apontam que a marca de 100 milhões de celulares em operação foi ultrapassada no ano de $2007^{1}$ no Brasil. Isto influencia fortemente o ambiente escolar, uma vez que estudantes de todas as idades se apropriam rapidamente das tecnologias disponibilizadas no atual mercado de bens de consumo. Mesmo crianças pequenas, ao iniciarem seus estudos oficiais na escola, já serão usuários veteranos destas tecnologias, uma vez que são exploradores e inventores naturais. Estas tecnologias têm ainda um potencial inexplorado no contexto da aprendizagem de ciências [BENENSON, 2001].

As práticas escolares modernas valorizam principalmente os componentes lógicos e lingüísticos do conhecimento humano. Uma razão para a relutância de educadores em reconhecer o valor do componente visualespacial no pensamento químico tem a ver com a crença de que apenas as linguagens verbal e matemática podem ser rigorosas. Desta forma as imagens serviriam apenas como meras ilustrações. No entanto, a sofisticada linguagem pictórica da química é, por si só, uma linguagem altamente estruturada [EGE, 1994].

Partindo do pressuposto que um dos objetivos gerais do ensino é o preparo para o exercício da cidadania, os resultados das pesquisas realizadas nas instituições de ensino nos últimos anos revelam que a educação, de forma geral, não tem alcançado este objetivo. Já se sabe que a formação do cidadão

1 http://www.agenciabrasil.gov.br/noticias/2007/02/21/materia.2007-02-21.1892357943/. Acessado em 12/10/2007. 
não se dá apenas no processo institucional escolar, mas em conjunto com outros grupos sociais em que o mesmo está inserido [LEMKE, 2001].

O ensino atual de Ciências, em particular da Química, presente atualmente na maioria das instituições de Ensino Médio na forma de currículo obrigatório, não alcança o objetivo geral deste nível de ensino. Muitas vezes o formato exclusivamente textual em que são apresentados os conteúdos e as atividades de ensino, leva a um envolvimento e participação de maneira superficial por parte do aluno, já que o mesmo se encontra inserido em um meio social que privilegia a comunicação e informação em formato áudio-visual [LÉVY, 1998].

Assimilar as mudanças, inovações e transformações pelas quais passa a sociedade e, conseqüentemente a educação, é um processo complexo que não depende apenas de vontade política. Este processo deve considerar a escola como local para desenvolvimento de pesquisa sobre o ensino de ciências, em particular a Química, articulada à pesquisa com a universidade.

Parte da preocupação pela melhoria no Ensino de Química se reflete na quantidade de publicações de cunho científico voltadas para a mesma nos últimos anos, como necessidade da atualização do ensino desta ciência tanto para o ensino médio quanto para o superior. As pesquisas na área de Ensino de Química foram iniciadas na década de 1970, e apesar de serem de boa qualidade, os pesquisadores envolvidos ainda são poucos no Brasil. Em uma pesquisa recente, BEJARANO e CARVALHO [2000] analisaram as publicações de teses e dissertações realizadas entre os anos de 1972 a 1995, demonstrando que o quadro em que se encontra o Ensino de Química no Brasil está se modificando.

Segundo este estudo, na década de 1970 foram contabilizadas apenas 6 publicações sobre Educação em Química entre 68 em Ensino de Ciências. Entre os anos de 1990 e 1995 foram 39 publicações em Química entre 225 em Ciências. No total, entre 1970 e 1995 as publicações das áreas de Ensino de Ciências ficaram divididas da seguinte forma: 250 em ensino de Física (43,7\%); 86 em ensino de Biologia (15,1\%); e 70 em ensino de Química (12,2\%). O restante se divide em Educação em Saúde, Educação Ambiental e Geral. A área de ensino de Física se desenvolveu fortemente, enquanto que a Biologia e 
a Química apresentaram baixa porcentagem de teses e dissertações.

Na década de 1980 a pesquisa no Ensino de Química teve um impulso importante com a organização do primeiro Encontro de Debates sobre o Ensino de Química (EDEQ) realizado no Rio Grande do Sul, e também do primeiro Encontro Nacional de Ensino de Química (ENEQ) em 1982 realizado na UNICAMP. Além disso, em 1988 foi constituída a Divisão de Ensino na Sociedade Brasileira de Química (SBQ) durante a XI Reunião Anual da Sociedade Brasileira de Química (RASBQ). No entanto, já na primeira RASBQ em 1978 sediada em São Paulo ocorreu a primeira seção coordenada de trabalhos de pesquisa em Ensino de Química [FRANCISCO, 2006].

Também se constatou o início de uma descentralização da região sudeste frente às pesquisas. Novas universidades em outras regiões do Brasil estão investindo no Ensino de Química. Além disso, as publicações que antes eram voltadas basicamente ao Ensino Médio e com foco temático em conteúdo, método, currículos e programas, apresentam uma mudança voltada para a formação de professores, focada no Ensino Superior. Desta forma, a melhoria na formação de professores de ciências é uma preocupação legítima diante da grande evasão dos cursos de graduação e alto índice de repetência de disciplinas que foram constatados nesta pesquisa. Como o professor é um fator multiplicador e foco central entre o aluno e o conhecimento, estes novos investimentos poderão contribuir para uma melhoria na qualidade de Ensino de Química.

FRANCISCO [2006] faz um estudo do crescimento da pesquisa no Ensino de Química a partir dos trabalhos da seção de Ensino de Química (ED) apresentados nas Reuniões Anuais da Sociedade Brasileira de Química (RASBQ) de 1999 a 2005. Neste período de sete anos foram apresentados 879 trabalhos na seção ED, sendo que a quantidade de trabalhos apresentados a cada ano quase que dobrou (de 85 trabalhos em 1999 para 161 trabalhos em 2005). A porcentagem média dos trabalhos apresentados na seção ED no período citado foi de $6,73 \%$ em relação ao total de trabalhos apresentados.

Dos 879 trabalhos apresentados na seção ED um total de quase $60 \%$ foi classificado dentro do tópico "recursos didáticos" ou "conteúdo-método". Dentro destes dois tópicos, o segundo tema mais abordado foi o de tecnologias da 
informação e comunicação, sendo o tema experimentação o mais abordado (Tabela 2). É importante ressaltar que o nível escolar preferencial abrangido nos trabalhos neste período foi o Ensino Médio (54,57\%).

\begin{tabular}{|c|c|}
\hline Tópicos & $\begin{array}{c}\text { Focos temáticos preferenciais } \\
\text { Experimentação (17\%) } \\
\text { Tecnologias (6\%) }\end{array}$ \\
\hline Conteúdo-Método & Experimentação (59\%) \\
\hline Recursos Didáticos & Tecnologias (13\%) \\
\hline
\end{tabular}

Tabela 2. A tabela mostra os focos temáticos preferenciais dos tópicos "conteúdo-método" e "recursos didáticos" de acordo com estudo feito por FRANCISCO [2006] dos resumos da seção ED apresentados nas Reuniões Anuais da Sociedade Brasileira de Química (RASBQ) de 1999 a 2005.

A utilização de tecnologias da informação e comunicação, em especial o computador, é um assunto que tem interessado diversos âmbitos da sociedade e, nas últimas décadas, tem mobilizado representantes da política educacional em nível nacional no Brasil.

Como importante exemplo, o Programa Nacional de Informática na Educação (Prolnfo) do Ministério da Educação (MEC) previu a instalação de 100 mil computadores em 16 mil escolas públicas de ensino básico até o ano de 1999. A partir deste programa foram constituídos laboratórios de informática educativa com uma série de ferramentas e metodologias para o auxílio à aprendizagem. Paralelamente à instalação dos laboratórios, o MEC vem desenvolvendo ações que objetivam formar professores especialistas em informática educativa através de cursos presenciais e a distância ${ }^{1}$. Esses especialistas serviriam de multiplicadores do projeto em Núcleos de Tecnologia Educacional (NTE), através de programas de formação continuada, visando à capacitação de professores lotados em escolas que receberam laboratórios de informática do Ministério da Educação.

No entanto vários problemas prejudicaram a implantação e o uso apropriado dos laboratórios de informática, desde a entrega de computadores em quantidade inferior ao inicialmente previsto, passando pela formação precária dos especialistas

1 http://www.proinfo.mec.gov.br. Acessado em 12/10/2007. 
multiplicadores, os quais receberam treinamento exclusivo em ferramentas corporativas de edição de texto e planilha, até a falta de incentivo na multiplicação do conhecimento em informática, relativos à carga horária e papel do professor laboratorista [OLIVEIRA, 2001].

Um outro exemplo importante é o programa Universidade Aberta, que oferecerá, ao ser executado em plena capacidade, dez mil vagas em cursos superiores oferecidos a distância ${ }^{1}$. No ano de 2006 foi iniciado um curso piloto de graduação em Administração de Empresas em dezessete estados e no Distrito Federal, com duração de quatro anos, que utilizará como plataforma um sistema de código aberto² desenvolvido pela Secretaria de Educação a Distância do MEC.

O desenvolvimento de recursos computacionais é uma importante contribuição para o ensino de muitas áreas de conhecimento, e neste trabalho procuramos somar uma contribuição para o Ensino de Química.

\section{3 - Uso da capacidade de processamento dos computadores com fins educacionais}

Atribui-se a Thomas Watson, o então presidente da IBM em 1943, a frequentemente citada declaração de que o mesmo não enxergava um mercado mundial para mais do que cinco computadores. É importante lembrar que esta declaração teria sido feita quando a percepção comum dos computadores era de uma máquina que ocupava completamente o tamanho de uma sala [GALL, 2002]. Desde então, a constante miniaturização dos computadores é considerado um dos fatores que levaram à disseminação do mesmo em vários âmbitos da sociedade, em especial a sala de aula.

O computador tem tido um profundo impacto em nossa sociedade. Grandes organizações governamentais, da indústria e de finanças, para citar alguns exemplos, têm dependido cada vez mais da eficiência e relativa confiança da automatização de suas operações. A partir de 1989, o avanço da tecnologia da informação teve um ritmo surpreendentemente mais acelerado, de forma a desempenhar papéis cada vez mais importantes no cotidiano das pessoas e na educação. A vinculação das tecnologias da informação à educação gerou posturas diversas. A postura inicial teve como resultados

1 http://www.uab.mec.gov.br. Acessado em 12/10/2007.

2 http://www.eproinfo.mec.gov.br. Acessado em 12/10/2007. 
trabalhos em que a utilização do computador para o ensino pode ser caracterizada simplesmente como uma versão computadorizada dos métodos de ensino tradicionais, de forma a reproduzir de forma computadorizada o que acontece na sala de aula.

O termo "computador" originalmente apareceu na língua inglesa (computer) no século dezessete e se referia aos trabalhadores especializados em pesquisas e cálculos matemáticos. Computadores mecânicos não tiveram nenhum impacto na sociedade até o final do século dezenove. Nesta época foram inventados uma variedade de aparelhos de cálculos e alguns chegaram a ter importância econômica na sociedade da era industrial. Máquinas que eram capazes de organizar e tabular dados através de cartões perfurados foram utilizadas no censo dos Estados Unidos da América em 1890 [GALL, 2002].

O ensino através da informática tem a sua origem no ensino com o uso das máquinas, utilizada em 1924 por Sidney Pressey, o qual inventou uma máquina para corrigir testes de múltipla escolha. Esta idéia foi trabalhada posteriormente por B.F. Skinner em 1950, o que resultou em uma máquina para ensinar com o conceito de instrução programada, muito utilizada no final de 1950 e início da década de 1960 de forma impressa. Também no início da década de 1960, com o advento do computador, estes módulos passaram a ser implementados com o auxílio do mesmo, o que ficou conhecido como "instrução auxiliada por computador" (Computer-Aided Instruction, ou CAI), conhecidos na versão brasileira como PEC (Programas Educacionais por Computador) [VALENTE, 2003]. Durante a década de 1960 houve um grande investimento por parte do governo americano na produção de material instrucional do tipo CAI, tanto em cursos de leitura e matemática para o ensino fundamental quanto para o ensino superior [SUPPES, SMITH e BEAR, 1975]. Na essência, não havia diferença entre o estudante pressionar uma tecla para a próxima tela, ou virar a página de um livro.

A partir da década de 1980 o uso do computador na educação passou a ser visto não como "máquina de ensinar", mas como uma nova mídia educacional, como ferramenta de complementação, de aperfeiçoamento e de possível mudança na qualidade de ensino. O computador passou a ser usado 
como um instrumento para a aprendizagem, o que ficou conhecido como aprendizagem assistida por computador (Computer Assisted Learning - CAL) [WADDICK, 1994]. A partir desta nova perspectiva, tenta-se utilizar o computador de forma integrada, onde os recursos tecnológicos devem ser adaptados à forma de aprendizagem dos alunos, num contexto que se preocupe com o método e com a abordagem educacional [EICHLER e DEL PINO, 2000].

Até antes da década de 1980 o uso do computador influenciava fortemente o usuário numa prática instrucional militarista, uma vez que o uso do computador estava baseado apenas no estímulo e resposta, como dispositivo de entrada e saída de dados. Como os dispositivos de visualização estavam ausentes o usuário se limitava a fornecer dados ao computador e esperar respostas em formato exclusivamente textual ou numérico.

No final da década de 1980 e no inicio da década de 1990, com a crescente aceitação do computador de uso pessoal, o desenvolvimento da interface gráfica do usuário em conjunto com o mouse substituíram a antiga interface do tipo linha de comando, baseada em texto, como padrão da interação entre o ser humano e da máquina. Além disso, a capacidade de processamento gráfico evoluiu para um nível realístico de fotos digitais. Áudio e vídeo em formato digital, que inicialmente demandavam hardware especializado, se tornaram padrões mundiais para qualquer sistema computacional pessoal. O CD e DVD emergiram como mídias preferenciais para armazenagem e envio de dados.

A mudança da função de tecnologias computacionais junto à educação acontece juntamente com um questionamento da função da escola e do papel do professor. A verdadeira função do aparato tecnológico não deve ser o ensino propriamente dito, mas sim criar condições de aprendizagem. Desta forma o professor deixa de ser apenas repassador da informação e passa a ser criador de ambientes virtuais de aprendizagem, com vistas a ser um facilitador do processo de desenvolvimento intelectual do aluno. As tendências de uso do computador na educação já mostram que ele pode ser um importante aliado neste processo que estamos começando a entender [VALENTE, 2003].

Ao desenvolvermos o ambiente virtual descrito neste trabalho, 
procuramos utilizar as tecnologias da informação e comunicação disponíveis na atualidade. Além disso, procuramos selecionar atividades de ensino que privilegiassem uma forma colaborativa de aprendizagem presencial, conforme descrito no capítulo de metodologias.

\section{4 - TIC's e os problemas da educação}

A avaliação de programas de tecnologia educacional requer que pesquisadores prestem bastante atenção à pergunta: tecnologia para quê? Alguns programas de tecnologia educacional focalizam na aquisição de habilidades de letramento e aritmética através de exercício e prática. Outros programas têm como intenção promover o aprendizado de novas formas básicas de busca de informação, comunicação, resolução de problemas e reflexão [COLEMAN e PENUEL, 2000].

Existem muitas divergências quanto ao uso de tecnologias da informação e comunicação na educação, a despeito do grande impacto que o computador pessoal tem tido na educação em muitos países. A despeito destas divergências o casamento entre as TIC's e a educação foi inevitável. Para muitos educadores existe maior necessidade de providenciar acesso e recursos para uma quantidade cada vez maior de estudantes. Outros se focalizam na melhor forma de integrar as tecnologias computacionais na sala de aula, particularmente quando a experiência tecnológica de muitos professores é muito limitada [ROBLYER e EDWARDS, 2000].

Os proponentes do uso de TIC's na educação geralmente apontam para o crescente número de computadores tanto em escolas quanto em laboratórios de pesquisa. Os oponentes podem ser de dois tipos. Aqueles que vêem os benefícios das TIC's e estão preocupados a respeito da exclusão digital. Outros ainda vêem o investimento em tecnologias computacionais como uma diversificação dos fundos que podem ser mais bem gastos na melhoria de livros texto ou outros numerosos esforços curriculares [STOLL, 1999].

Outra preocupação para a educação seria o papel do mercado de programas computacionais educativos. Embora existam programas educacionais de qualidade, muitos programas computacionais direcionados ao uso educacional utilizam pedagogias limitadas, como práticas de algoritmos, 
que são relativamente fáceis de produzir e distribuir. Ironicamente, em algumas áreas de ensino, podem ser encontrados tanto produtos de alto valor de mercado, quanto produtos de baixo custo do tipo shareware criados por educadores e programadores, ou mesmo produtos sem qualquer custo. Diante deste quadro o uso principal dos computadores em educação na atualidade está ao redor de ferramentas de produtividade, como o Microsoft Office ${ }^{\circledR}$, que são escolhidas e compradas, não pelo seu potencial educacional benéfico, mas porque representam o estado atual de consumo no comércio e na indústria [GALL, 2002].

Outra crítica a respeito da utilização de TIC's na educação é a de que boa parte dos materiais instrucionais é baseada mais nas capacidades tecnológicas de hardware e software do que em teorias instrucionais ou achados de pesquisas em ensino [YANG e MOORE, 1996].

Ainda há também a crítica de que os materiais educacionais disponíveis seriam mera compilação das aulas presenciais. Na época da introdução de cursos on-line muitos profissionais da educação reclamavam que havia pouco suporte para que os professores pudessem traduzir seus cursos refinados por toda uma carreira na sala de aula para o formato hipertexto [ELLIS e HAFNER, 2003].

No atual modelo de utilização comercial e educacional de computadores uma série de desvantagens e dificuldades pode ser apontada. Em primeiro lugar o poder computacional está fisicamente restringido. Uma grande parte de computadores são imóveis devido a uma série tópicos, como conectividade, segurança, etc. A possibilidade de uso de computadores portáteis individuais para fins educacionais com acesso a redes sem fio ainda permanece como propostas até o presente momento. Projetos de grandes empresas e grupos de pesquisadores apontam para um futuro uso em larga escala de computadores portáteis de baixo custo, como o $\mathrm{OLPC}^{1}$ e outros. No momento, até mesmo com uma ótima infra-estrutura de redes sem fio, computadores portáteis são substancialmente mais caros comparados com computadores de mesa de mesmo poder computacional.

$1 \quad$ http://www.olpc.org. Acessado em 12/10/2007. 
Em segundo lugar as constantes atualizações oferecem dificuldades constantes aos usuários. No caso dos hardwares melhoras significativas na velocidade de processadores e na capacidade de armazenamento são difíceis de serem ignoradas. No caso dos softwares, o atual estágio de licenciamentos e a constante criação de atualizações demandam mudanças freqüentes. Com muito mais freqüência do que nunca, os softwares são atualizados para manter compatibilidade e atualidade com a evolução do hardware do que para melhorar a usabilidade ou ganhar funcionalidade.

Em terceiro lugar a necessidade de conectividade e o desejo de convergência de recursos provocam uma tirania das massas. Desta forma os padrões computacionais frequentemente se baseiam na necessidade de controle de custos e na facilidade da administração. Embora estas preocupações sejam legítimas, elas podem estar em oposição direta para com a necessidade de diversidade e inclusão em padrões educacionais [GALL, 2002].

Durante as décadas de 1970 e 1980, alguns pesquisadores apresentaram-se extremamente otimistas quanto ao uso de tecnologias no processo educativo [ROTH, WOSZCZYNA e SMITH; 1996], cogitando a possibilidade de solução da maioria dos problemas educacionais. Esta postura tem sido criticada pela ausência de um aprofundamento em questões fundamentais, que envolvem um estudo pormenorizado de situações de ensino com o uso das novas tecnologias. Outros pesquisadores, no extremo oposto, apóiam sua descrença em questões reais, como a precariedade material presente no sistema educacional, ou mesmo filosóficas, alegando que o computador nos conduziria inevitavelmente a um tecnicismo desumanizador.

Recentemente, educadores e pesquisadores começaram a despertar para uma nova postura sobre o assunto, que se caracteriza por uma visão crítica diante da tecnologia, porém não cética, numa compreensão do contexto histórico, em que as condições políticas, econômicas e sociais são consideradas variáveis importantes nos processos educacionais, o que constituiria uma visão pró-ativa. Nesta, considera-se conjuntamente o uso de tecnologias, os métodos empregados e a redistribuição de papéis no contexto 
educacional. Neste contexto, entende-se que a tecnologia não pode ser vista como resolvedora dos problemas educacionais [VALENTE, 2003].

No início da década de 1980, época do primeiro ciclo de informatização das escolas brasileiras indicava-se que o uso do computador em atividades de ensino ou de aprendizagem não deveria ser visto como uma saída para a crise do sistema educacional brasileiro. Um estudo de caso sobre a informática educativa indicou que o computador estava sendo subutilizado nas escolas, uma vez que a grande maioria dos professores desconhecia as formas de utilização dessa tecnologia no processo de ensino [OLIVEIRA, 1997]. Desta forma, juntamente com a disponibilização de recursos tecnológicos, é necessário que os professores sejam treinados de forma apropriada nas ferramentas computacionais e que haja um programa permanente de capacitação didática dos mesmos, tanto sobre as ferramentas computacionais quanto sobre a utilização das mesmas como ferramentas de apoio ao ensino.

Além do poder público, a iniciativa privada também tem destinado importante soma de recursos à aquisição de computadores e acesso a internet. A principal justificativa declarada, tanto por parte do poder público quanto da iniciativa privada, é a necessidade de orientar as ações educacionais e a formação dos alunos para as necessidades da sociedade que está imersa em um mundo globalizado, em que as oportunidades de trabalho exigem cada vez mais conhecimentos e habilidades para agir com computadores. Não há dúvidas sobre as exigências do mercado de trabalho mobilizarem a atenção daqueles que planejam e executam as ações educativas, mas as mesmas não devem ser definidoras dos propósitos das ações educativas que se realizam em sala de aula [GIORDAN, 2005].

De fato, uma análise das políticas subjacentes à informatização educacional [APPLE, 1986], feita a partir de referenciais sócio-críticos, concluiu que as necessidades e visões dos professores, dos alunos e da comunidade eram forçadas a se ajustar à tecnologia, ao invés de essa ser adequada àquelas. Na conclusão da análise, o autor lembrou que uma das tarefas dos educadores é assegurar que a entrada de novas tecnologias em sala de aula se dê por razões educacionais criteriosas e não por interesses de mercado. 
Daí a importância do envolvimento de educadores no processo de desenvolvimento de tecnologias educacionais, de maneira que os recursos tecnológicos disponíveis sejam criteriosamente inseridos ou adaptados em atividades de ensino, e não o contrário.

\section{5 - Possibilidades de uso de TIC's na educação na atualidade}

As TIC's podem ser utilizadas como padrão de comunicação em cursos a distância, e podem ser utilizadas também em cursos presenciais. Existem atualmente experiências de cursos mistos (a distância e presenciais) que descrevem o uso das TIC's como mediadoras dos módulos a distância [TENG e TAVERAS, 2004; WELKER e BERARDINO, 2005].

Para possibilitar um aprendizado mais efetivo com o uso de ferramentas computacionais são necessários melhores formatos de apresentação de conteúdos para os usuários. Os formatos numéricos nem sempre são os melhores, especialmente quando a principal característica a ser enfatizada é a tridimensionalidade ou espacialidade. Também são necessárias interfaces mais intuitivas para edição e mudança de informação.

Atualmente existem diversas ferramentas tecnológicas que utilizam os protocolos de comunicação presentes na internet, e que constituem alternativas para a aprendizagem com o uso do computador. Deve-se partir do princípio que um software não funciona automaticamente como desencadeador do processo de aprendizagem, mas deve-se considerar que o sucesso de um software em promover a aprendizagem depende de sua integração ao currículo e às atividades da sala de aula.

As ferramentas mais amplamente utilizadas atualmente, sendo verdadeiros sinônimos de computador para muitos usuários iniciantes, são os processadores de texto, planilha e imagem. Estes tipos de programas estão amplamente presentes em pacotes básicos de ferramentas de empresas

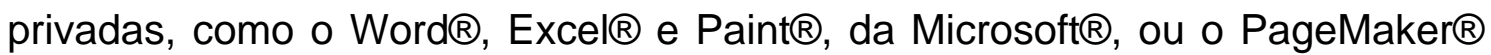
da Adobe ${ }^{\circledR}$, quanto de grupos que desenvolvem software livre a partir da filosofia de código aberto como a OpenOffice ${ }^{1}$. É a partir do uso deste tipo de ferramenta que os usuários de computadores desenvolvem habilidades de uso

1 http://www.openoffice.org. Acessado em 12/10/2007. 
do teclado com a digitação de textos escolares e o desenvolvimento de variados tipos de gráficos e desenhos. Atualmente é possível disponibilizar editores de texto em páginas hipertexto, onde o usuário pode editar o conteúdo de páginas na internet a distância, sem a necessidade de instalar algo em seu computador ou mesmo conhecer a linguagem HTML [BERNERS-LEE et al., 1992]. Dentro deste contexto estão os plug-in's FCKeditor ${ }^{1}$ e $\mathrm{HTMLarea}^{2}$. Em ambientes virtuais de ensino este tipo de ferramenta pode ser utilizado para que cursistas publiquem suas atividades de ensino diretamente no ambiente já em formato hipertexto, de forma que seus colegas de curso e os responsáveis por acompanhar as atividades possam avaliar e opinar [BARBOZA e GIORDAN, 2007].

Os navegadores de hipertexto constituem um outro tipo de ferramenta universalmente presente em computadores. Podemos citar como exemplo o Internet Explorer ${ }^{\circledR}$, da Microsoft ${ }^{\circledR}$, e o Firefox ${ }^{\circledR}$, da Mozilla ${ }^{\circledR}$. É através deste tipo de ferramenta que os usuários têm acesso à gigantesca quantidade de páginas tipo hipertexto existente hoje na internet. Além da quantidade de páginas, quase qualquer tipo de conteúdo pode ser encontrado atualmente na internet, do conhecimento humano oficial ao alternativo. É a partir deste tipo de ferramenta, via de regra, que usuários de cursos a distância acessam os ambientes virtuais de ensino, as ferramentas de busca, os correios eletrônicos, etc.

Outro tipo de ferramenta bastante utilizada são os programas tocadores (também conhecidos como players) e editores de áudio e vídeo, como o RealPlayer ${ }^{\circledR}$, da RealNetworks ${ }^{3}{ }^{3}$, o QuickTime ${ }^{\circledR}$, da Apple $\AA^{4}$, o Windows Media ${ }^{\circledR}$, da Microsoft ${ }$, e o Audacity ${ }^{5}$, feito por um time de desenvolvedores de software livre. Através destes programas os usuários têm contato com 0 conteúdo de áudio e vídeo disponibilizados nas páginas hipertexto da internet. Este tipo de ferramenta pode ser integrado em ambientes virtuais de ensino quando se deseja disponibilizar conteúdos de áudio e vídeo sobre assuntos de

1 http://www.fckeditor.net. Acessado em 12/10/2007.

2 http://www.htmlarea.com. Acessado em 12/10/2007.

3 http://www.real.com/player. Acessado em 12/10/2007.

4 http://www.apple.com. Acessado em 12/10/2007.

5 http://audacity.sourceforge.net. Acessado em 12/10/2007. 
interesse do tema trabalhado no ambiente ou curso [BARBOZA e GIORDAN, 2007].

O meio de acesso de visualização tem se modificado ao longo da última década, bem como as próprias ferramentas disponibilizadas. De tutoriais instalados no próprio computador, passando por materiais acessíveis por CDROM e, finalmente, aqueles acessíveis pela internet. As ferramentas também foram modificadas da simples visualização até a manipulação e mesmo criação de objetos moleculares tridimensionais. De simples ferramentas de desenhos, as ferramentas computacionais disponíveis para o Ensino da Química contam agora até mesmo com ferramentas de simulação por mecânica e dinâmica moleculares, disponíveis há poucos anos apenas para o ambiente de pesquisa cientifica. $\mathrm{O}$ acesso à internet faz com que não seja necessário a utilização do poder de processamento do computador local, de forma que é possível utilizar a configuração e a capacidade de computação de outros computadores, mesmo clusters, remotamente.

No caso da química existem diversas ferramentas de edição e visualização de objetos moleculares bidimensionais ou tridimensionais. Este tipo de ferramenta é importante uma vez que boa parte do conhecimento químico se refere a uma dimensão submicroscópica, portanto não-visível a olho nu ou com ajuda de aparelhos. Com estas ferramentas podem-se visualizar objetos que enfatizam importantes aspectos do conhecimento químico sobre os átomos, moléculas e estruturas supramoleculares. Um importante visualizador de objetos moleculares gratuito e disponível na internet é o plug-in MDLChime $^{1}$, amplamente utilizado pela comunidade acadêmica. Outros exemplos seriam os applets escritos em linguagem Java ${ }$, como o jmol $^{2}$, e o $\mathrm{JaMM}^{3}$. Além dos visualizadores utilizados conjuntamente com navegadores, existem ainda os programas que não dependem de navegadores como o Chemdraw ${ }^{4} \mathrm{e}$ o ChemSketch ${ }^{5}$, que além da capacidade de visualização, oferecem ao usuário a possibilidade de editar os objetos moleculares visualizados.

1 http://www.mdl.com. Acessado em 12/10/2007.

2 http://jmol.sourceforge.net. Acessado em 12/10/2007.

3 http://www.iumsc.indiana.edu/graphics/jamm2.1.html. Acessado em 12/10/2007.

4 http://www.cambridgesoft.com. Acessado em 12/10/2007.

5 http://www.acdlabs.com/download. Acessado em 12/10/2007. 
Existem também ferramentas de criação de objetos animados não específicos da química, como o Flash ${ }$, da Adobe $^{1}$, e o $3 \mathrm{dMax} \circledast$, da AutoDesk $^{2}$. Com estas ferramentas é possível criar animações a partir de elementos gráficos simples que simulam movimentação em duas e três dimensões.

Os softwares de simulação por mecânica e dinâmica molecular constituem uma ferramenta de uso avançado para criação de objetos moleculares com propriedades correspondentes ao conhecimento químico atual. Através destas ferramentas, podem-se criar objetos moleculares tridimensionais utilizando parâmetros teóricos e empíricos para simular o distanciamento relativo e a movimentação atômica e molecular. Pacotes de programas como $\mathrm{VMD}^{3}$, Gaussian ${ }^{4}$, Insight ${ }^{\circ}{ }^{5}$, e Tinker $^{6}$ são amplamente utilizados no ambiente acadêmico para estudo de propriedades de substancias químicas e bioquímicas e apresentam, além de grande capacidade de cálculo de propriedades, uma avançada interface gráfica que permite ao usuário manipular cada variável e parâmetro dos cálculos a serem feitos. Devido à grande especificidade dos cálculos e das teorias que os embasam, este tipo de programa fica restrito a utilização por parte de especialistas em simulações químicas, tornando muito difícil a utilização por parte de iniciantes em química.

Nos últimos anos esforços têm sido feitos para que este tipo de recurso computacional fique disponível de forma acessível para os não-especialistas. A Indiana University, em seu centro de estrutura molecular ${ }^{7}$, desenvolveu uma interface simplificada de utilização de recursos computacionais, onde o usuário pode submeter uma estrutura em um programa de simulação e visualização molecular. Neste caso o usuário obtém como retorno uma figura estática bidimensional da estrutura submetida.

Neste trabalho descrevemos o desenvolvimento de um programa

\footnotetext{
1 http://www.macromedia.com. Acessado em 12/10/2007.

2 http://usa.autodesk.com/3dsmax. Acessado em 12/10/2007.

3 http://www.ks.uiuc.edu/Research/vmd. Acessado em 12/10/2007.

4 http://www.gaussian.com. Acessado em 12/10/2007.

5 http://www.accelrys.com. Acessado em 12/10/2007.

6 http://dasher.wustl.edu/tinker. Acessado em 12/10/2007.

7 http://www.iumsc.indiana.edu. Acessado em 12/10/2007.
} 
computacional, chamado Construtor, onde usuários iniciantes podem obter, de forma simplificada, objetos moleculares tridimensionais e dinâmicos. Esta ferramenta foi acoplada a um ambiente virtual de ensino, e seu desenvolvimento e utilizações serão detalhadas nos próximos capítulos.

A capacidade de processamento dos computadores parece não mais ser um entrave ao desenvolvimento de ambientes virtuais e programas computacionais com finalidades diversas. Computadores com processadores e memória suficientes para a execução de sistemas operacionais diversos podem ser comprados ao custo de menos de quinhentos dólares americanos quando da defesa desta dissertação, e mesmo clusters de oito processadores podem ser montados de forma caseira ao custo de mil e duzentos dólares americanos $^{1}$.

\section{6 - Representação Estrutural em Química}

O termo "representação" tem provocado tanto entusiasmo quanto ceticismo, da mesma forma que a maioria dos conceitos epistemológicos chave. Para muitos historiadores da ciência e cientistas a possibilidade de repensar uma categoria epistemológica familiar e abrí-la para um novo escrutínio se torna um intrigante desafio intelectual. Em tais estudos este termo se reporta a significação ou referência sem qualquer comprometimento simultâneo com o realismo. De modo oposto, falas sobre "representação" no discurso filosófico frequentemente implicam um investimento no realismo, na crença de que textos, figuras e outros sistemas simbólicos correspondem ou não a objetos autônomos no mundo perceptível. Os problemas e questões acerca do realismo, correspondência e verdade não serão abordados neste trabalho, mas será assumido como pressuposto que representações são elementos intrínsecos das ciências experimentais, em nosso caso, a Química [KLEIN, 2001].

Do ponto de vista da moderna teoria da semiótica, que será discutida no próximo capítulo, representar é estar em lugar de outro, numa tal relação que, para certos propósitos, possa ser considerado como se fosse esse outro [PEIRCE, 2005, pp 61].

1. http://www.calvin.edu/ adams/research/microwulf/. Acessado em 10/09/07. 
As representações são parte importante do conhecimento químico, por ser uma ciência que trata da matéria em uma escala submicroscópica, ou nanoscópica. Os químicos desenvolveram uma variedade de representações, tais como modelos moleculares, estruturas químicas, fórmulas, equações e símbolos, para investigar fenômenos da natureza [HOFFMAN e LASZLO, 1991].

Estas representações apresentam espacialmente as imagens de partículas e suas formas geométricas em duas ou três dimensões de forma a compor uma linguagem espacial [BALABAN, 1999; HABRAKEN, 2004; NYE, 1993]. Elas apresentam informações que não podem ser facilmente entendidas de outra forma [LARKIN e SIMON, 1987] e permitem aos químicos pensarem visualmente e expressarem informação eficientemente em um formato visual.

Representações químicas tais como estruturas moleculares e modelos atômicos são diagramas, parcialmente esquematizados e parcialmente icônicos, que retratam conceitos abstratos e aplicam convenções para ilustrar tanto os componentes quanto sua organização [HEGARTHY, CARPENTER e JUST, 1991]. A relação entre a disposição espacial e os conceitos químicos associados não é arbitrária, como a relação entre palavras e conceitos, nem é um isomorfismo de primeira ordem, como a relação entre pinturas e seus referentes [WINN, 1991]. Assim, em um contínuo de diferentes formas de informações escritas, as representações químicas são tipicamente mais abstratas do que diagramas pictóricos, mas ainda assim representam a informação de uma forma analógica não-arbitrária [WU, 2003].

As diferentes formas de representação química têm sido utilizadas para comunicar conceitos a estudantes do Ensino Médio e Superior. Atualmente os currículos e livros usam uma variedade de representações visuais para introduzir conceitos químicos fundamentais [NOH e SCHARMANN, 1997]. Tais representações deveriam ser objetivas naquilo que pretendem representar. Representações ideais devem mostrar apropriadamente características criticas de um determinado domínio de conhecimento, e ao mesmo tempo ignorar as informações irrelevantes [RIEBER, 1996]. É esperado dos estudantes uma habilidade de compreender e manipular mentalmente as representações 
químicas, o que é crítico para a compreensão de conceitos e para a condução de pesquisas científicas [WU, 2003].

\subsection{1 - As dimensões do conhecimento químico e suas representações}

Há um certo consenso em torno da idéia de o conhecimento químico ser construído pela combinação de três dimensões da realidade: macroscópica, submicroscópica e simbólica [JOHNSTONE, 1993; GABEL e BUNCE, 1994; GARNET et al. 1995; DORI et al., 1996; GABEL, 1998; BOWEN, 1998; ARDAC e AKAYGUN, 2004). Parte dos fenômenos e processos químicos são perceptíveis e observáveis através de informações sensoriais e medições que se concretizam em uma dimensão macroscópica. Dentro do paradigma atômico-molecular vigente, no qual a natureza particulada da matéria é a fundamentação teórica para interpretar esses fenômenos e processos, admitese uma outra dimensão da realidade, a submicroscópica ou nanoscópica, onde ocorrem fenômenos envolvendo o movimento e a interação de partículas. Em uma dimensão simbólica, substâncias, partículas e transformações são representadas por meio de símbolos, fórmulas e equações químicas, bem como expressões algébricas, tratando-se portanto de uma materialização semiótica da realidade.

As representações do nível simbólico do conhecimento químico, mesmo em representações muito simples, podem se referir tanto ao nível macroscópico, como no caso da representação do estado de agregação (sólido, liquido, gasoso) de determinada substância, quanto ao nível submicroscópico, como na própria representação do elemento químico e da atomicidade da substância. Estas representações se relacionam também com as operações lógico-matemáticas que podem ser executadas com o auxílio das representações.

Segundo HOFFMAN e LASZLO [1991], as representações simbólica e submicroscópica evoluíram de analogias fenomenológicas de experiências sensoriais no nível macroscópico, as quais permitem aos químicos terem uma linguagem comum para sua investigação conjunta e são utilizadas para a comunicação entre profissionais da comunidade [KOZMA et al., 2000]. Ainda de acordo com HOFFMAN e LASZLO, as representações químicas são 
metáforas, modelos ou construtos teóricos da interpretação química da natureza e da realidade, com o que está de acordo NYE [1993], que também sugere serem essas características determinantes da formação de um pensamento que diferencia a Química de outras ciências.

O nível submicroscópico do conhecimento químico esteve representado, por muito tempo na história desta área de conhecimento, por letras e figuras geométricas bidimensionais. A visualização tridimensional desta dimensão do conhecimento químico se tornava um exercício da imaginação dos praticantes desta disciplina, através de esforço intelectual na intenção de agrupar propriedades isoladas. Atualmente é possível visualizar, e mesmo manipular, objetos moleculares tridimensionais que reúnem e simulam de forma apropriada o conhecimento a respeito da natureza particulada da matéria.

Professores e pesquisadores do Ensino de Química têm realizado estudos sobre como promover o entendimento conceitual em estudantes do ensino médio [WU, KRAJCIK e SOLOWAY, 2001] e superior [KOZMA e RUSSEL, 1997] através do desenvolvimento da habilidade de representação das três dimensões do conhecimento químico. Nestes estudos percebeu-se que os estudantes parecem dominar as construções simbólicas da química tratando equações como processos matemáticos, ao invés de pensar nas mesmas representações de processos dinâmicos e interativos. Outras pesquisas apontam para o fato de estudantes poderem elaborar a resposta correta para problemas em química tendo apenas um entendimento conceitual limitado [SAWYER, 1990; SMITH e METZ, 1996], sem que tenham se apropriado, por exemplo, da simbologia associada. É neste sentido que se tem defendido a resolução satisfatória de problemas desafiando o estudante a se apropriar de dispositivos de pensamento da química, o que é observado em situações que os permitam correlacionar o fenômeno em sua dimensão macroscópica com a representação simbólica e submicroscópica.

Estudos também apontam para o fato de estudantes de Ensino Médio e Superior apresentarem dificuldade para compreender fenômenos e transformações químicas em termos do modelo de partículas atualmente aceito [GARNET, GARNET e HACKING, 1995]. Alguns autores têm interpretado estas dificuldades de aprendizagem como oriundas da natureza particulada, abstrata 
e não observável da química, e da necessidade de rápida transferência entre os três níveis de representação [JOHNSTONE, 1991; GABEL, BRINER e HAINES, 1992].

Existe uma dificuldade maior por parte dos estudantes na compreensão do nível submicroscópico e na representação do nível simbólico, pelo fato de as mesmas serem invisíveis e abstratas. Desta forma, devido ao pensamento dos estudantes se basear em informações sensoriais, os mesmos têm a tendência em permanecer no nível macroscópico em suas explicações sobre os fenômenos e propriedades de substâncias [BEN-ZVI, EYLON e SILBERSTEIN, 1988; GRIFFTHS e PRESTON, 1992].

Professores, pesquisadores e profissionais da química operam apropriadamente entre as dimensões do conhecimento, enquanto estudantes têm dificuldade em estabelecer ligações entre estes níveis. Muitos estudantes não são capazes de gerar uma representação equivalente para determinados tipos de representação [KOZMA e RUSSEL, 1997] devido à inconsistências conceituais [KEIG e RUBBA, 1993] ou dificuldade de visualização espacial [TUCKEY, SELVARATNAM e BRADLEY, 1991].

Estudantes iniciantes em química com freqüência são solicitados a traduzir os níveis de representação macroscópica e submicroscópica do conhecimento químico para um formato simbólico de fórmulas e equações. De uma forma geral os estudantes de Ensino Médio frequentemente não são capazes de gerar representações equivalentes entre modelos de fórmula, configuração eletrônica e bola-vareta [KEIG e RUBBA, 1993], ou entre representações bidimensionais e tridimensionais [ROZZELLE e ROSENFELD, 1985; SRINAVASAN e OLSON, 1989].

Os estudantes nem sempre entendem o papel da representação que é assumida pelo professor. A familiaridade com o propósito de cada nível de representação pode melhorar a compreensão por parte do estudante e sua habilidade de explicar um conceito [TREAGUST, CHITTLEBOROUGH E MAMIALA, 2003].

Desta forma, parece bastante provável que a utilização de modelos, analogias e gráficos computacionais em situações estruturadas de ensino seja produtiva para os estudantes se apropriarem das formas de pensamento 
químico, conforme alguns estudos têm sugerido. Visualizações apropriadas podem melhorar a percepção do aprendiz sobre o objeto ou sobre as idéias representadas no objeto. É necessário, portanto considerar tanto a fundamentação epistemológica da Química nas especificidades do seu paradigma atômico-molecular, quanto a organização das atividades de ensino quando nos propomos a introduzir um meio mediacional estranho à sala de aula e à própria concepção de ensino de química predominante nas escolas de Ensino Médio.

\subsection{2 - As representações químicas e as tecnologias da informação e comunicação}

A representação dos níveis de conhecimento através de múltiplos meios tem sido eficaz no ensino de química, através da utilização de diferentes sistemas de símbolos para representar informações em diferentes formas [KOZMA, 1991]. As características superficiais de cada sistema de símbolos podem melhor representar certas características da informação [KOZMA e RUSSEL, 1997].

De uma forma geral, estudantes se sentem confortáveis com as representações da dimensão macroscópica do conhecimento químico. As representações que se referem exclusivamente a este nível do conhecimento geralmente são compostas por esquemas intuitivos com significados facilmente apreensíveis. Não existem muitos tipos diferentes ou específicos do conhecimento químico de representações macroscópicas. Com o advento dos computadores atualmente é possível lançar mão de fotos, desenhos e animações que representem características e fenômenos macroscópicos.

Já na dimensão submicroscópica do conhecimento químico os estudantes geralmente apresentam dificuldades de compreensão e em habilidades de expressão oral ou grafada. As reclamações mais freqüentes são que existem muitas representações e de muitos tipos, e que os significados das representações são de difícil apreensão. A contribuição que os computadores trouxeram na compreensão deste nível do conhecimento químico está na possibilidade de representação simultânea dos três níveis do conhecimento, de forma a integrar e transitar por cada um destes níveis. 
Estudantes não sentem dificuldade com as representações do nível submicroscópico quando as mesmas são apresentadas apenas como ilustração ou curiosidade em livros didáticos e aulas expositivas. No entanto, ao serem questionados quanto ao significado espacial de representações bidimensionais geralmente aparecem dificuldades e concepções alternativas. Esta dimensão do conhecimento provavelmente foi a maior privilegiada com a chegada do computador nas práticas de ensino da atualidade, uma vez que se tornou possível a visualização de características da natureza particulada da matéria que não podem ser visualizadas de outra forma.

Pesquisadores têm sugerido diferentes abordagens instrucionais como apoio ao ensino de química, como adaptação de estratégias de ensino baseado no modelo de mudança conceitual [KRAJCIK, 1991], integração de atividades de laboratório na aula em classe [JOHNSTONE e LETTON, 1990], uso de modelos concretos [COPOLO e HOUNSHELL, 1995] e uso de tecnologias como ferramentas de aprendizado [BARNEA e DORI, 1999; KOZMA et al., 1996; WU, KRAJCIK e SOLOWAY, 2001]. O uso de modelos concretos juntamente com tecnologias como ferramentas de aprendizado parece promissor [WU, KRAJCIK e SOLOWAY, 2001].

Estudos têm indicado bons resultados de aprendizagem quando da utilização de objetos moleculares concretos como forma de visualização do modelo de partículas e das transformações químicas associadas [COPOLO e HOUNSHELL, 1995; GABEL e SHERWOOD, 1980; TALLEY, 1973]. Alguns autores têm observado um efeito cumulativo de longo prazo na compreensão dos estudantes sobre os fenômenos quando são submetidos à manipulação destes objetos moleculares concretos [GABEL e SHERWOOD, 1980]. Este tipo de visualização é apontado com um dos mais utilizados na atualidade, pois simplifica, ilustra e permite a exploração da estrutura e do processo químico associado. No entanto estes objetos são rígidos e geralmente em quantidade limitada, o que restringe seu uso a construção de moléculas com tamanho reduzido de átomos [BARNEA e DORI, 1999].

Uma das funcionalidades dos aplicativos computacionais é veicular simulações em nível molecular do fenômeno químico, o que não é possível através de outros meios de representação. A utilização dessa tecnologia como 
ferramenta de ensino permite a visualização de simulações dinâmicas projetadas tridimensionalmente, o que tem auxiliado estudantes a representar simbolicamente os processos químicos e, portanto a interpretar a fenomenologia nas dimensões macroscópica e submicroscópica [WILLIAMSON e ABRAHAM, 1995]. Este suporte ao aprendizado provido pelas tecnologias computacionais tem sido considerado como um atributo específico e particularmente útil desses meios para representar as três dimensões do conhecimento químico, pois elas têm a qualidade de dispor a informação em sistemas simbólicos diferentes, mas coordenados [KOZMA, 1991]. Representações múltiplas ligadas entre si permitem ao estudante visualizar interações entre moléculas e entender os conceitos químicos relacionados [KOZMA et al., 1996].

\subsection{3 - Tridimensionalidade e representações computacionais}

Um problema que os estudantes freqüentemente enfrentam é a realização de tarefas que exigem habilidades de visualização tridimensional, bem como visualização tridimensional de moléculas que são representadas bidimensionalmente em livros [BARNEA e DORI, 1999]. Descrições verbais ou bidimensionais são muito menos adequadas para representar as relações estruturais e inferenciais contidas em uma única representação tridimensional. Representações tridimensionais oferecem a possibilidade de abstração de informações relevantes a partir do formato visual oferecido no material instrucional.

Há evidencias de que alguns tipos de representação, especialmente quando animada e dinâmica, podem melhorar a visualização tridimensional dos estudantes [SEDDON e SHUBBER, 1985; SEDDON e MOORE, 1986; TUCKEY, SELVARATNAM e BRADLEY, 1991]. Estudos mostraram que a construção de conceitos está estreitamente relacionada ao formato visual com que os estudantes tiveram contato durante seu aprendizado [CLARK e PAIVIO, 1991; PAIVIO, 1986]. É neste sentido que alguns autores têm defendido a integração entre gráficos computacionais e representação tridimensional como uma forma efetiva de melhorar a habilidade de visualização no ensino de 
ciências [KISER, 1990; RODRIGUEZ, 1990; WILEY, 1990; BEZZI, 1991; BARNEA e DORI, 1996].

A utilização de objetos moleculares virtuais gerados por computadores, além de permitir a disposição de múltiplas representações coordenadas e tridimensionalmente projetadas, também favorece variados tipos de manipulação destes objetos, como translação, rotação, aumento ou redução de tamanho. Quando estudantes podem manipular estes objetos de forma variada eles podem se tornar familiarizados com seus detalhes [WU, KRAJCIK e SOLOWAY, 2001]. Uma outra vantagem da visualização computacional é a possibilidade de se representar moléculas de, virtualmente, qualquer tamanho, dependendo apenas da capacidade de processamento do computador.

É neste sentido que o desenvolvimento de aplicativos computacionais para atividades de ensino se apresenta como uma alternativa potencialmente transformadora das práticas escolares e da construção de conhecimento entre estudantes, desde que seja considerada a correlação das três dimensões do conhecimento químico na organização das atividades e se investigue os ditames das ações mediadas pelos aplicativos, que são fundamentalmente diferentes daquelas realizadas em situações de ensino ancoradas na experimentação ou qualquer outra forma de acesso à fenomenologia, isso porque o estatuto do fenômeno se altera radicalmente quando é transposto da bancada para a tela do computador [GIORDAN, 1999].

\subsection{4 - Objetos Moleculares computacionais: visualizações, animações e simulações}

Os termos visualização, animação e simulação têm sido utilizados nos mais variados contextos com diferentes significados. Especialmente dentro da área de Ensino de Ciências muitas vezes estas palavras são utilizadas como sinônimos [RIBEIRO e GRECA, 2003]. Em virtude disso se faz necessário demarcar o que entendemos por cada um destes termos.

\section{Visualização}

Simulações são frequentemente confundidas com visualizações e animações. WOLFF e YEAGER [1993] sugeriram que visualização, dentro do 
contexto das tecnologias da informação e comunicação, é o processo pelo qual seres humanos utilizam softwares para converterem um ponteiro de valores digitais em uma imagem. Deve ser notado que, diferente de uma simulação verdadeira, um algoritmo matemático deve ser utilizado, mas unicamente para converter valores de um formato para outro. Não existe normalmente nenhuma capacidade real de produção de diferente cenários. Entretanto, a apresentação em formato visual pode permitir a identificação de mais informações do que uma inspeção visual dos dados em outro formato.

A visualização também pode ser entendida como um processo computacional de geração, para o usuário, de estímulos sensoriais (visuais, auditivos, entre outros), de um ambiente virtual simulado. O usuário de um sistema de visualização geralmente posiciona-se em frente a algum dispositivo de visualização, que pode ser um ou mais monitores de vídeo ou telas de projeção, ou os "veste", como no caso dos HMDs (Head Mounted Displays), que surgiram com o advento da realidade virtual [ISDALE, 1993].

O processo de visualização de imagens tridimensionais, ou que simulem tridimensionalidade através de métodos de coloração e sombreamento, são muito importantes no processo de ensino e aprendizagem da química. Pedir a estudantes iniciantes em química para desenvolverem uma nova maneira de enxergar representações compostas por letras e números é quase um ideal artístico, onde objetos devem ser vistos de uma forma que não a comum, como é o caso da simetria molecular [KORKMAZ e HARWOOD, 2004].

\section{Animações}

A literatura sobre educação e ensino de ciências apresenta atualmente quantidade significativa de estudos sobre 0 uso de representações computacionais direcionadas ao ensino de química nos níveis médio e superior. Uma das características freqüentemente utilizadas em ambientes de aprendizado multimídia baseados em computadores é a utilização de imagens animadas, ou que simulem movimentação. Qualquer elemento gráfico em uma tela de computador pode ser animado, mas a utilização mais freqüente é a animação de figuras. Estas animações podem ser usadas para mimetizar uma percepção tridimensional, através da disposição de um objeto sob perspectivas 
variadas, e do uso de técnicas de sombreamento. Elas podem ser utilizadas para direcionar a atenção do observador para aspectos importantes da apresentação, oferecer conhecimento procedimental, demonstrar a dinâmica de determinado assunto ou permitindo o aprendizado exploratório através da manipulação de determinado objeto. Além disso, elas podem ter um efeito suplantativo [SALOMON, 1994] quando ajudam iniciantes a realizar um processo cognitivo que não poderiam realizar sem este suporte externo.

Animações são mais difíceis de serem classificadas, uma vez que algumas, não todas, são verdadeiras simulações de acordo com a definição aceita neste trabalho. Ou seja, uma animação baseada em um algoritmo lógico ou matemático, a qual demonstre o resultado de mudança de valores para as variáveis do sistema seria classificado como simulação. Esta distinção não é tão clara quanto desejada. Muitos trabalhos que são descritos como animações poderiam ser categorizados como simulações [RIBEIRO e GRECA, 2003].

Uma animação pode ser definida como um grupo de imagens mostradas consecutivamente de forma a dar uma aparente sensação de movimento das imagens visualizadas [BURKE, GREENBOWEE e WINDSCHITL, 1998]. Visualizações animadas são mais eficientes dos que as estáticas na identificação, por parte dos estudantes, de comportamentos naturais da matéria, bem como de possíveis relações de causalidade [KAISER et al., 1992].

Animações computacionais podem servir como ferramenta poderosa ao prover os estudantes com acesso dinâmico a representações diagramáticas que encontram paralelo em estruturas de conhecimento subjacentes. Os ambientes multimídia provêem um rico suporte visual para uma compreensão conceitual e muitas oportunidades para a interpretação de imagens em contextos significativos [HSU, 2006].

Estudantes que têm acesso apenas a imagens estáticas parecem criar conceitos alternativos do fenômeno e tem dificuldade em visualizar comportamentos dinâmicos próprios de um nível submicroscópico [WILLIAMSON e ABRAHAM, 1995].

Animações computacionais são geradas a partir de aplicativos gerais de edição gráfica, sem necessariamente incluir valores empíricos de propriedades 
das substâncias ou das transformações obtidos em pesquisa cientifica, e intencionam enfatizar determinadas características superficiais macroscópicas ou submicroscópicas sem obedecer a escalas de tempo ou tamanho. Os softwares assim obtidos podem mimetizar um ou mais aspectos do fenômeno, conceito ou procedimento representado [RIBEIRO e GRECA, 2003]. Isto, porém, não os tornam simulações em si mesmas, pelo fato de não levarem em consideração equações e grandezas importantes para o fenômeno, de forma que possuem muitos aspectos pictóricos que não correspondem ao conhecimento cientifico atualmente aceito.

\section{Simulações}

Simulações químicas são valiosas ferramentas de ensino que permitem aos estudantes explorarem sistemas químicos de forma rápida e efetiva. Em alguns casos uma simples visualização gráfica auxilia os estudantes a entender o processo no nível molecular de uma forma muito melhor que o ensino tradicional. Existem dois tipos básicos de interação com simulações, sejam elas geradas diretamente pela ação humana ou por computador: a forma textual e a forma gráfica. Neste trabalho nos propomos a estudar o papel da formas gráficas de simulação.

Embora não exista consenso sobre estes termos entre profissionais da área de Modelagem Molecular e Ensino de Ciências, uma definição útil seria a de que, uma verdadeira simulação, utiliza um algoritmo matemático ou lógico para reproduzir as características selecionadas de um sistema de forma que o efeito de mudança individual ou conjunta de variáveis possa ser observado. $O$ algoritmo deve estar fundamentalmente relacionado ao sistema considerado e não deve ser meramente utilizado para selecionar uma variedade de observações previamente criadas.

As simulações computacionais já se tornaram tão importantes para alguns tipos de investigação científica quanto béqueres, reagentes e vidrarias. Muitos estudos se baseiam fortemente em simulações, uma vez que a observação direta é difícil ou impossível. Podemos citar como exemplo alguns problemas ambientais, tais como formação de smog ou depleção da camada de ozônio, os quais são complexos demais e se estendem por áreas muito 
grandes para serem entendidas por observação direta apenas. De forma semelhante, simulações moleculares de transformações químicas podem oferecer formas mais rápidas e menos custosas de identificar as prováveis correlações entre a estrutura molecular e a desejada reatividade.

As simulações químicas devem ser mais bem entendidas como instrumentos de pensamento, em lugar de realidade observável, que ficam evidentes em concepções alternativas de professores e estudantes. As simulações também podem ser vistas como analogias mecânicas do processo ou sistema estudado [MÉHEAUT, 1997]. Uma simulação também pode ser entendida como uma situação criada artificialmente, planejada para permitir que iniciantes de quaisquer áreas do conhecimento experimentem novos comportamentos de um sistema sem o risco de punição por falhas na realização [NADLER e NADLER, 1994].

Um grande diferencial das simulações em relação às animações, já que em ambos os casos pode-se visualizar a movimentação de átomos ou moléculas na tela, é que simulações têm um forte caráter de flexibilidade, uma vez que múltiplas possibilidades, em alguns casos infinitas, podem ser visualizadas pelo estudante. Além disso, as simulações tendem a ser mais interativas porque geralmente o usuário determina o que quer visualizar.

\section{Simulações: aplicações no ensino}

Nas últimas décadas passou-se a considerar que o computador pode transformar a forma de ensino, assim como vem alterando a forma da construção da Ciência, mudando as relações entre teoria e experimentação, uma vez que se trata de um instrumento que possibilita aos estudantes a compreensão da relação causal entre as variáveis, com o isolamento e a manipulação de um parâmetro por vez e o teste de hipóteses alternativas, oportunizando aos alunos a participação em atividades de simulação.

O computador permite tentativas repetidas de um experimento com considerável facilidade em uma quantidade limitada de tempo, providencia respostas imediatas, permite observação imediata de representações gráficas, e oferece um ambiente flexível que permite aos estudantes realizarem seus próprios planos [FISHER, 1997]. Além disso, encoraja o estudante a pensar 
hipoteticamente e testar suas hipóteses através da identificação e controle de variáveis [SWAAK, JOOLINGEN, JONG, 1998].

O aprendizado através de simples descoberta com o uso do computador pode não ser ideal quando é completamente não assistida e unicamente exploratória em natureza. De uma forma geral foi observado que ocorrem maiores ganhos para estudantes com maiores habilidades computacionais, e maiores perdas para estudantes com poucas dessas habilidades [BERGER et al., 1994].

Modelos moleculares dinâmicos representam uma classe promissora de modelos computacionais que podem ter ampla aplicação na educação em ciências. Um modelo molecular dinâmico utiliza mecânica clássica na construção de campos de força para computar a movimentação de grupos atômicos e moléculas em duas ou três dimensões. Muitas das idéias centrais da termodinâmica podem ser vistas em tais modelos, como temperatura, conservação de energia, aumento de entropia, o princípio de eqüipartição, e muitos outros.

Estes modelos são amplamente utilizados em pesquisa científica pela mesma razão que podem ser utilizados em educação para explorar o comportamento emergente de sistemas muito complexos e para seguir a evolução destes sistemas com o tempo. A habilidade de visualizar o que acontece com grupos de átomos e moléculas sob condições e regras variadas dá ao pesquisador um entendimento aprofundado e intuitivo do sistema em estudo, de forma que as interações no nível atômico se tornam tão familiares e previsíveis quanto o nosso mundo macroscópico [PALLANT e TINKER, 2004]. Portanto a visualização é uma estratégia potencialmente complementar à interpretação destes fenômenos quando estes são descritos por modelos moleculares dinâmicos de campos de força.

\section{Simulações: aplicações na pesquisa científica}

Nos últimos anos, cientistas, ligados a atividades acadêmicas e industriais, têm criado e validado novas ferramentas através da engenharia de software, as quais integram as ciências que se beneficiam das visualizações moleculares, como a química, a bioquímica e a biologia molecular, com as 
tecnologias de hardware e software disponíveis na atualidade [FLETCHER, 1980; FRENKEL, 1990].

Vários campos de estudo têm surgido e ferramentas específicas tornam possível aos cientistas a tomada de decisões dirigidas pelo conhecimento em suas pesquisas, as quais evitam sínteses onerosas e testes de compostos químicos com provável ineficiência, tornando mais rápida a resolução de problemas específicos na descoberta de novas drogas e compostos na indústria farmacêutica, agroquímica e de biotecnologia [GRANT, 1995].

A utilização de softwares que exploram bancos de dados químicos e biológicos permite a procura de compostos por sub-estrutura, similaridade de propriedades e estereoisomeria, os quais auxiliam no estabelecimento de prioridades de síntese e compra de matérias-primas em grandes indústrias. Outras ferramentas computacionais, como por exemplo, na área da Bioinformática, têm ajudado pesquisadores a extrair informações úteis de grandes volumes de dados gerados por tecnologias de ponta que caracterizam os métodos modernos de pesquisa.

Softwares também são utilizados em análise, visualização e processamento de dados de RMN multidimensional para visualização do espectro e da estrutura molecular obtidos. A construção de modelos gráficos e estatísticos que relatam as propriedades de moléculas e suas estruturas e subestruturas são utilizadas para predição de propriedades ou atividade de novos compostos.

No campo da Modelagem Molecular têm sido criadas ferramentas para visualização, manipulação, análise, comparação e construção de estruturas químicas, bem como ferramentas de alinhamento de estruturas primárias de proteínas e de alças. Outras ferramentas auxiliam na identificação de sítios de ligação no interior ou na superfície de macromoléculas através da identificação de propriedades como hidrofobicidade e área acessível ao solvente. A seleção de possíveis ligantes também pode ser feita por softwares que determinam a energia relativa de ligação receptor-ligante a partir de um banco de dados do próprio pesquisador ou obtido de forma comercial [RODRIGUES, 2001].

Por meio de cálculos de energia potencial pode ser feito o refinamento do posicionamento tridimensional de estruturas obtidas através de vários 
métodos, como por exemplo, por cristalografia de raios-X, homologia, ou ainda estruturas criadas a partir de modificações de estruturas tridimensionais anteriormente conhecidas. A simulação de movimentos moleculares permite a obtenção de possíveis conformações e propriedades termodinâmicas. $O$ annealing simulado permite o estudo dos possíveis confôrmeros e a energia mínima associada aos mesmos [KIRKPATRICK, 1983].

Objetos moleculares gráficos podem ser gerados a partir de simulações computacionais obtidas com campos de força da dinâmica e da mecânica moleculares. Os elementos gráficos assim gerados a partir de aplicativos específicos para estudo de propriedades de substâncias e transformações químicas estão intimamente relacionados ao ambiente de pesquisa cientifica. Para realizar estas simulações são utilizados valores teóricos ou empíricos de propriedades químicas, como ângulos e distâncias de ligações, e as escalas de tempo e tamanho são parametrizadas por equações matemáticas descritoras das leis físicas que fundamentam os fenômenos. Estes cálculos computacionais têm como resultado números que estão relacionados a grandezas físicas e propriedades. A interpretação destes resultados pode ser feita com o auxílio de softwares que utilizam estes tipos de dados para gerar objetos gráficos, resultado de uma simulação computacional. As imagens obtidas por estes softwares serão consideradas neste trabalho como simulações.

\section{Simulações: tipos possíveis}

De acordo com a definição de simulação assumida acima, modelos puramente matemáticos seriam os exemplos mais claros de simulações. Estes podem variar de modelos computacionais de macromoléculas de importância biológica a simples cálculos com planilhas. Os resultados podem ser apresentados como visualizações complexas ou simples gráficos cartesianos. Até mesmo uma simples planilha de cálculo pode ser uma poderosa ferramenta de ensino ao permitir que os estudantes explorem as mudanças do sistema diante das mudanças de variável.

Muitas simulações de instrumentos se encaixariam na definição acima, embora a interação possa ocorrer com o auxílio de uma interface gráfica mais 
complicada que se assemelhariam à própria operação do equipamento. Em alguns casos estas simulações podem prover um recorte mais apropriado de visão do instrumento, de forma que estudantes possam visualizar de forma mais clara as funções dos vários componentes. É possível mostrar até mesmo aspectos da operação que normalmente são invisíveis, como o caminho de um feixe na região do infravermelho em um espectrofotômetro. O ponto chave no caso da simulação é se o caminho do feixe infravermelho irá variar ou não em resposta direta às mudanças de variável escolhidas pelo estudante.

Simulações moleculares computacionais obtidas através de parâmetros teóricos e empíricos são muito úteis nas condições apropriadas. Estas geralmente usam uma sofisticada ferramenta de cálculo para determinar configurações moleculares e permitir ao usuário observar os efeitos das mudanças de algumas das variáveis. Esta variação vai além da simples determinação de distâncias e ângulos de ligação, para incluir medidas do efeito de mudanças estruturais no espectro ou na reatividade, além de outras propriedades. Programas computacionais de modelagem molecular atuais se tornaram, entre outras coisas, um poderoso complemento aos exercícios laboratoriais, os quais auxiliam na visualização do nível submicroscópio e na comparação do mesmo com o que é observado em seus experimentos.

Muitos tipos de ferramentas computacionais de ensino de ciências não poderiam ser incluídos na definição proposta para simulações. Podemos citar como exemplo programas computacionais que simplesmente apresentam imagens sem o uso de um algoritmo, ou que não ofereçam a oportunidade de mudança de variável não poderiam ser classificados como simulações. Figuras animadas e animações são importantes ferramentas de ensino, as quais também não se encaixariam nesta definição. Deve ser deixado claro que a exclusão de tais ferramentas da definição de simulação não desmerece o seu uso e importância de forma alguma. Por outro lado um programa computacional de titulação que inclui um compêndio de ilustrações estáticas mostrando vários estágios de uma titulação, e que também executa cálculos para determinar qual seria a ilustração a ser mostrada ao usuário em cada estágio preencheria os requerimentos. 
Deve ficar claro que existem vários tipos de simulações, as quais podem ser úteis em diferentes situações. Em muitos casos, a simulação é uma proposta única de experiência educacional que pode veicular aos estudantes conceitos refinados ao longo de muitas décadas.

\section{Simulações: Objetos Moleculares}

Em qualquer um dos casos, o objeto molecular é uma representação imagética da entidade molecular e pode ser concebido como uma metáfora do que supomos ocorrer na dimensão submicroscópica da matéria e não um retrato da realidade. Chamamos de objetos moleculares as representações das partículas submicroscópicas, cujo meio de veiculação pode variar desde o papel, passando pelos conjuntos plásticos, isopor e madeira, chegando à tela do computador ou à projeção holográfica [GIORDAN, 2005]. Varia-se o meio e também as formas de representação, nesse caso com o objetivo de destacar uma ou outra propriedade da molécula. Portanto, o objeto molecular é uma entidade iconográfica que serve tanto para propósitos de indexação e referência, como para mimetizar determinada propriedade molecular, tendo esta a possibilidade de ser simulada por meio de um sistema de equações quando o objeto é veiculado pelo computador.

Pelo fato de as simulações computacionais levarem em consideração as propriedades do sistema em estudo, as mesmas podem ser visualizadas como objetos moleculares virtuais dinâmicos, uma vez que é possível simular a variação de propriedades como distância e ângulos de ligação. A partir destas simulações podem ser gerados filmes simulando o movimento conjunto dos átomos nas moléculas e em sistemas moleculares.

Uma decorrência importante da manipulação de diversas formas de representação é a possibilidade de conferir um efeito vinculante entre a variável, de natureza teórica, e a forma de representação da propriedade, de natureza imagética. A visualização de objetos moleculares mediada pelo computador parece, portanto, promover a vinculação entre a simulação de uma propriedade da molécula e sua representação em um mesmo meio. Esta é uma situação de alto valor didático capaz de mobilizar as ações dos alunos na 
manipulação do objeto, na elaboração discursiva e também na elaboração de significado [GIORDAN, 2005].

Apesar de existirem diversas ferramentas de visualização e construção de objetos moleculares virtuais destinadas a pesquisadores, como por exemplo, aplicativos de mecânica e dinâmica molecular, a utilização das mesmas por alunos do Ensino Médio ou mesmo por alunos iniciantes no ensino superior em química é dificultada em razão da profundidade do conhecimento envolvido nos cálculos e no controle de variáveis.

Até o início da década de 1990 programas computacionais de modelagem molecular estavam disponibilizados apenas para o ambiente de pesquisa cientifica. No final da década de 1990 [EALY, J. 1999] este tipo de programa computacional já era utilizado por estudantes de graduação em química. O diferencial apontado pelos estudantes de graduação foi a possibilidade de visualização de propriedades dinâmicas anteriormente apenas imaginadas. No entanto algumas dificuldades de uso foram prontamente identificadas neste estudo. Os programas de modelagem molecular ainda são voltados para o ambiente de pesquisa cientifica, de forma que a utilização dos mesmos requer conhecimento avançado tanto na utilização do programa, quanto de sistemas operacionais tipo UNIX no qual a maioria destes programas é executado. Em alguns casos os estudantes precisam fornecer valores de variáveis, como constantes de força de ligações químicas, detalhes do processo de minimização de energia ou ainda detalhes sobre a organização das informações de entrada e saída fornecidas pelos aplicativos.

Para que os estudantes tenham acesso às aplicações de visualização molecular baseadas em simulações, é necessário desenvolver ferramentas que simplifiquem a transferência de dados entre as interfaces de entrada e saída e simultaneamente possibilitem o controle sobre variáveis que afetam a visualização.

Até o momento não conhecemos nenhuma interface voltada para alunos iniciantes que ofereça a possibilidade de uso de programas de modelagem molecular de forma simplificada, onde não seja necessário fornecer parâmetros teóricos e empíricos para a execução apropriada do programa. Também não temos conhecimento de aplicativos de visualização molecular que permitam 
aos estudantes a criação de suas próprias representações de sistemas moleculares por meio de interfaces simplificadas que não exijam conhecimento aprofundado das teorias de modelagem molecular.

Diante desta situação, onde tecnologias de informação e comunicação estão fortemente presentes na sociedade, e também já marcam sua presença na sala de aula, e considerando que o uso de ferramentas computacionais pode auxiliar na construção de conceitos dinâmicos específicos no conhecimento químico, e diante da ausência de aplicativos de criação e visualização molecular, que provavelmente tem limitado a utilização de computadores em situações de ensino-aprendizagem de química, temos desenvolvido um programa computacional de comunicação do usuário com aplicativos de simulação para construção de objetos moleculares tridimensionais virtuais [GIORDAN e GOIS, 2005] chamada Construtor, o qual será discutido logo adiante.

O aplicativo computacional Construtor será objeto de investigação e de desenvolvimento de um ambiente virtual de Ensino de Química, o qual enfatiza a relação existente entre os níveis submicroscópico e simbólico do conhecimento químico. Nas atividades de ensino do ambiente virtual os estudantes utilizam modelos moleculares concretos e virtuais, que são importantes mediadores no processo de construção do conhecimento químico, uma vez que signos grafados e falados, próprios desta área de conhecimento, constantemente trazem dificuldade para a compreensão de conceitos da química por parte dos estudantes.

O ambiente virtual resultado deste trabalho é acessível pela internet através de navegadores comuns de hipertexto, e pode ser utilizado para o ensino presencial ou a distância. O programa computacional Construtor faz uso das possibilidades do atual estágio de desenvolvimento das tecnologias da informação e comunicação, as quais permitem a utilização tanto da capacidade remota de softwares específicos de cálculos de estruturas, quanto da capacidade de comunicação e gráfica local de computadores de uso pessoal. Com este software, estudantes de Ensino Médio podem construir estruturas químicas sob demanda e de forma simplificada, a partir unicamente da fórmula estrutural condensada. 


\section{7 - Ambientes virtuais de ensino}

No âmbito educacional, a palavra diretamente relacionada à internet na atualidade é acesso. Desta forma pesquisadores e educadores trabalham no sentido de garantir o acesso do conhecimento para todos. Nos últimos anos o desenvolvimento das tecnologias da informação e comunicação caminha na direção de um formato padrão de acesso à informação, tanto presencial quanto a distância [KINZIE et al., 1996], o que vem sendo conhecido como convergência tecnológica ou digital.

O atual estágio de desenvolvimento das tecnologias de informação e comunicação permite a criação de ambientes virtuais que exploram as possibilidades de comunicação, processamento e capacidade gráfica dos computadores. Com isso torna-se necessário explorar novas estratégias de ensino, as quais ultrapassam as possibilidades das ferramentas antigas (livros, quadro negro e giz, etc). Especialmente para a educação em ciências, passouse a considerar que o computador pode transformar a forma de ensino, assim como vem alterando a forma da construção da Ciência, bem como mudando as relações entre teoria e experimentação [GIORDAN, 1999].

Uma grande vantagem dos ambientes virtuais é a possibilidade de uso de imagens de alta qualidade, sem o inconveniente aumento desproporcional de preço em comparação com os meios impressos em papel. Desta forma, os ambientes virtuais podem disponibilizar material de qualidade consideravelmente superior em relação a livros e revistas de conteúdo científico [BALABAN, 1999].

Em termos de educação, apresentações computacionais do tipo multimídia podem ser consideradas como tendo sucesso no desenvolvimento das tecnologias da informação e da comunicação. O formato inicial exclusivamente de texto no padrão de comunicação entre seres humanos e máquinas, e o uso principal como máquina de cálculos, fez dos computadores uma ferramenta natural para a matemática e as ciências exatas. $O$ formato multimídia abriu uma gama de aplicações computacionais para história, artes ou qualquer outra área onde imagens e sons podem ser gravados em formato digital ou mesmo gerados na forma de animações ou simulações [GALL, 2002]. 
Outra grande vantagem é que, ao contrário de ambientes virtuais de aprendizado que dependem da instalação de programas específicos em computadores pessoais, muitos ambientes acessíveis pela internet permitem um acesso mais amplo e independente de plataforma, e estão se tornando cada vez mais comuns [DORLAND, 2002].

Ambientes virtuais independentes de plataforma se constituem verdadeiramente em um modelo de desenvolvimento e distribuição de uma variedade de mídias através da internet. Ambientes virtuais baseados na linguagem HTML e em navegadores de hipertexto se consolidaram como mais apropriados para o desenvolvimento de novos ambientes de ensino a partir das universidades. Este conceito de desenvolvimento de ambientes virtuais é o mais barato, uma vez que é necessária apenas uma plataforma de programação, o que requer menos programadores e menos tempo de desenvolvimento, de forma que não é necessário desenvolver um código fonte para cada plataforma como, por exemplo, Windows ${ }^{\circledR}$, MacOS-X $®$, GNU-Linux ou BSD-Linux.

Além disso, tais ambientes podem ser livremente disponibilizados na internet, o que torna desnecessário o desenvolvimento de uma logística de produção em escala. A evolução do ambiente com novas implementações também é facilitada, uma vez que é necessário fazer as modificações apenas no computador servidor, e não em cada um dos computadores clientes ou usuários. Também se torna desnecessário desenvolver logística de marketing e distribuição, uma vez que os sites das universidades geralmente são os locais de desenvolvimento destes ambientes e já possuem bastante visibilidade na internet, o que acaba sendo também um incentivo para o contato de professores do ensino básico com o ambiente de pesquisa. Com isso os pesquisadores podem se focalizar no que realmente sabem fazer: pesquisa em ensino. Não é mais necessário que pesquisadores desta área se preocupem com o desenvolvimento de ambientes virtuais em várias plataformas, com a produção em escala ou a logística de distribuição de material [KINZIE et al., 1996].

Muitos trabalhos que tratam de ambientes virtuais abrangem a criação e desenvolvimento de sistemas de realidade virtual com diferentes níveis de 
detalhamento, onde o monitor de vídeo, ou equipamentos especializados, como capacetes e luvas que simulam as propriedades do ambiente, são utilizados como "uma maneira do homem visualizar, manipular e interagir com computadores e dados extremamente complexos" [AUKSTAKALNIS e BLATNER, 1992].

Como ambiente virtual, neste trabalho, não nos referimos a ambientes virtuais animados de imersão do tipo realidade virtual. Atualmente existem muito ambientes virtuais animados de imersão que tratam de assuntos relacionados ao conhecimento químico ${ }^{1}$. Neste trabalho desenvolvemos um ambiente virtual a partir de um conjunto de atividades estruturadas dentro de um tema escolhido como gerador de tópicos relacionados aos conteúdos de estruturas químicas. Estas atividades foram adaptadas para um formato de páginas tipo hipertexto, acessíveis pela internet com o uso de um computador, onde estão inseridas ferramentas para a criação e visualização de objetos moleculares virtuais e tridimensionais.

Os primeiros projetos de construção de ambientes virtuais de aprendizagem destinados à educação tiveram início em meados da década de 1990, depois de uma significativa mudança na internet, devido à criação do primeiro navegador de hipertexto, e também ao fato de a internet deixar de ser uma rede acadêmica, incorporando atividades da iniciativa privada. Antes do desenvolvimento de navegadores, era possível utilizar a internet por meio de protocolos de comunicação tipo texto, sendo que um grande avanço ocorreu com a tecnologia de janelas gráficas, cuja vantagem é permitir a representação da informação na forma de linguagem icônica.

Atualmente existem muitas plataformas de desenvolvimento de ambientes virtuais, conhecidas como coursewares, onde é necessário apenas inserir os conteúdos de conhecimento específico e escolher as ferramentas a serem utilizados pelos estudantes e professores/tutores a partir de um conjunto pré-determinado de ferramentas já adaptadas ao ambiente. Levando em consideração as plataformas de desenvolvimento de ambientes virtuais

$1 \quad$ http://www.vetl.uh.edu/ScienceSpace/ScienceSpace.html. Acessado em 12/10/2007. http://www.engin.umich.edu/labs/vrichel. Acessado em 12/10/2007. 
destinados à educação que podem ser acessados a partir de navegadores comuns, as mesmas podem ser de dois tipos em relação à filosofia de desenvolvimento. O primeiro tipo é desenvolvido como plataforma de código aberto, como o TelEduc ${ }^{1}$, o $\mathrm{Col}^{2}$, o Moodle ${ }^{3}$, o e-Proinfo ${ }^{4}$ e o CAPA ${ }^{5}$ onde vários desenvolvedores podem contribuir no desenvolvimento do código fonte do ambiente, independentemente de serem parte da equipe oficial de desenvolvimento. O segundo tipo se constitui em sistemas que funcionam em plataformas proprietárias, na qual a empresa que constrói o ambiente promove o seu desenvolvimento e controla a sua distribuição e venda, como o Web Course in a Box ${ }^{6}$, o Web Course Tools ${ }^{7}$, o Top Class ${ }^{8}$, o Virtual- $U^{9}$, o FirstClass $^{10}$, o WebAssign ${ }^{11}$, o WebCT ${ }^{12}$ e o Blackboard ${ }^{13}$.

As primeiras versões de ambientes virtuais de aprendizagem para educação foram modeladas com base em quatro estratégias [FRANCO, CORDEIRO e CASTILHO, 2003], com relação às suas funcionalidades:

- Incorporar elementos já existentes na web, como correio eletrônico e grupos de discussão.

- Agregar elementos para atividades específicas de informática, como gerenciar arquivos e cópias de segurança.

- Criar elementos específicos para a atividade educacional, como módulos para o conteúdo e a avaliação.

- Adicionar elementos de administração acadêmica sobre cursos, alunos, avaliações e relatórios.

\footnotetext{
1 http://hera.nied.unicamp.br. Acessado em 12/10/2007.

2 http://col.usp.br. Acessado em 12/10/2007.

3 http://moodle.org. Acessado em 12/10/2007.

4 http://www.eproinfo.mec.gov.br. Acessado em 12/10/2007.

5 http://www.lon-capa.org. Acessado em 12/10/2007.

6 http://www.madduck.com. Acessado em 12/10/2007.

7 http://www.webct.com. Acessado em 12/10/2007.

8 http://www.wbtsystems.com. Acessado em 12/10/2007.

9 http://www.virtual-u.org. Acessado em 12/10/2007.

10 http://www.softarc.com. Acessado em 12/10/2007.

11 http://www.webassign.net. Acessado em 12/10/2007.

12 http://www.webct.com. Acessado em 12/10/2007.

13 http://www.blackboard.com. Acessado em 12/10/2007.
} 
Assim, por meio dessas estratégias, foram criados os primeiros ambientes virtuais de aprendizagem para serem usados especificamente em atividades educacionais. Alguns ambientes de primeira geração foram metáforas de modelos de aprendizagem, por exemplo, "uma sala de aula virtual" [DORÉ e BASQUE, 1998].

Neste trabalho apresentamos um ambiente virtual em formato hipertexto desenvolvido sem o auxilio das plataformas de ambientes virtuais existentes atualmente. Este ambiente virtual deve ser acessado pela internet, e pode ser utilizado tanto para ensino a distância quanto para o ensino presencial. Escolhemos utilizar o sistema de forma presencial com os estudantes de ensino médio de uma escola pública da Rede Estadual de São Paulo. Fizemos esta escolha baseados no fato de estes estudantes nunca terem utilizado uma ferramenta de ensino a distância anteriormente. Além disso, se optássemos pela realização das atividades a distância os mesmos acessariam o ambiente a partir de seus lares ou de Lan-Houses, de forma que não estariam trabalhando juntos, como na sala de aula. Ao escolhermos trabalhar com o ambiente de forma presencial, e, portanto, numa sala com computadores, o fato de estarem todos juntos na mesma "sala de aula" mimetizou parcialmente a situação colaborativa de aprendizado cotidiano da escola, o que contribuiu de certa forma na espontaneidade da realização das atividades.

O desenvolvimento das tecnologias da informação e comunicação possibilitou a criação de ambientes virtuais específicos para o Ensino da Química na última década. Estes ambientes virtuais exploram as possibilidades tecnológicas disponíveis em cada época e incorporam os novos paradigmas que acompanharam a evolução tanto dos computadores de uso pessoal quanto do que se conhece hoje como internet. Antes de descrevermos o ambiente virtual desenvolvido neste trabalho, apresentamos uma revisão da bibliografia sobre os ambientes virtuais de Ensino de Química a partir de 1994, focalizando o potencial de uso das ferramentas de visualização dos mesmos.

\subsection{1 - Histórico dos Ambientes Virtuais para o Ensino de Química}

Realizamos uma revisão da bibliografia disponível sobre ambientes virtuais de Ensino de Química. Consideramos como ambientes virtuais de 
Ensino de Química os softwares que podem ser baixados da internet ou adquiridos de forma comercial, bem como aqueles que podem ser utilizados diretamente a partir dos sítios da internet. A partir desta revisão agrupamos os ambientes computacionais com opções de visualização em pelo menos um dos níveis de representação química (macroscópico, submicroscópico ou simbólico) e que fossem de utilização acessível a estudantes de Ensino Médio. Também era necessário que o ambiente possibilitasse a realização de atividades de ensino voltadas aos conteúdos próprios do Ensino Médio, de forma que ferramentas simples de visualização de objetos moleculares e softwares para pesquisadores ou para uso em Ensino Superior foram desconsideradas.

Título do Periódico

British Journal of Educational Technology

Educational Technology

Educational Technology Research and Development

Foundations of Chemistry

International Journal of Science Education

International Journal of Technology and Design Education

Journal of Educational Computing Research

Journal of Educational Technology Systems

Journal of Research in Science Teaching

Journal of Science Education and Technology

Research in Science and Technology Education

Science Education

Tecnologia Educacional

Tabela 3. Esta tabela mostra quais periódicos foram consultados para revisão da bibliografia nesta dissertação de mestrado.6

Sítios informativos ou contendo apenas atividades de ensino de química [BRITO, 2001] ou portais de repositórios de softwares ${ }^{1}$ também foram

1 http://www.needs.org. Acessado em 12/10/2007.

http://www.futuro.usp.br. Acessado em 12/10/2007. 
desconsiderados. Pesquisamos os ambientes virtuais divulgados nos periódicos de 1994 a 2006, num período total de 12 anos. Os periódicos consultados foram aqueles disponíveis na Biblioteca da Faculdade de Educação da Universidade de São Paulo. A Tabela 3 mostra os títulos pesquisados neste período e a Tabela 4 mostra os ambientes virtuais encontrados neste período bem como o ano de publicação do trabalho original e as opções de visualização disponíveis.

Nesta pesquisa encontramos vários ambientes virtuais relacionados ao ensino de química, os quais descrevemos logo abaixo. De uma forma geral pudemos observar três fases no desenvolvimento dos ambientes virtuais de ensino neste período quanto às tecnologias utilizadas e a filosofia de uso.

Em um primeiro momento os ambientes virtuais de ensino tinham como objetivo a disponibilização de apontamentos de aulas, tutoriais e exercícios práticos e resolução de problemas no computador através de mídias como disquetes e CD-ROM's. Estes ambientes não faziam uso dos recursos de comunicação em redes nem da capacidade de processamento gráfico disponível para usuários domésticos, a qual era utilizada quase que apenas para o ambiente de janelas. Em um segundo momento a preocupação dos desenvolvedores estava voltada para a inserção de conteúdos gráficos, como fotos e vídeos, em atividades de ensino, bem como a disponibilização destes conteúdos em formato de CD-ROM. Em um terceiro momento as comunidades de pesquisa em tecnologias educacionais se ocuparam com a tarefa de desenvolver ambientes virtuais voltados ao uso através da internet que podiam ser utilizados através de programas que eram baixados da internet e instalados nos computadores, primeiro na modalidade do ensino a distância, e em seguida também no ensino presencial, não apenas no ensino de Química ou de Ciências, mas no aprendizado de uma forma geral.

Atualmente observamos uma tendência de os ambientes virtuais serem utilizados diretamente a partir do navegador hipertexto, sem a necessidade de baixar e instalar programas específicos no computador. A idéia é trocar dados com o ambiente virtual diretamente pela internet e acessá-lo a partir do navegador. A partir disso são desenvolvidas as tecnologia de execução de serviços "do lado do servidor", no sentido de que o computador cliente, ou do 
usuário, seja algo parecido com um terminal de visualização, com todo o processamento pesado sendo feito no computador servidor através da internet. Neste perfil se encaixam os ambientes desenvolvidos nas linguagens PHP ou ASP em conjunto com bancos de dados como o MySQL ou PostgreSQL, bem como a tecnologia AJAX que combina linguagens JavaScript e XML com conceitos de programação para maximizar o processamento e a comunicação entre os computadores cliente e servidor.

\begin{tabular}{|c|c|c|}
\hline $\begin{array}{c}\text { Ano de } \\
\text { publicação }\end{array}$ & $\begin{array}{c}\text { Nome do ambiente } \\
\text { virtual }\end{array}$ & Opções de Visualização* \\
1994 & 4M:CHEM & Macro, Submicro e Simb \\
1996 & VisChem & Macro, Submicro e Simb \\
1997 & CHEMMAT & Macro, Submicro e Simb \\
1998 & ChemViz & Submicro e Simb \\
2000 & SMV:Chem & Macro, Submicro e Simb \\
2001 & eChem & Macro e Submicro \\
2002 & ChemSense & Submicro e Simb \\
2002 & ChemDiscovery & Macro, Submicro e Simb \\
2003 & CHEMnet & Macro, Submicro e Simb \\
2003 & Connected Chemistry & Macro e Submicro \\
2004 & Chemical Change & Macro, Submicro e Simb \\
2004 & Molecular Workbench & Submicro e Simb \\
\hline
\end{tabular}

Tabela 4. Esta tabela mostra de forma esquemática quais ambientes virtuais de ensino de química foram encontrados na revisão da bibliografia.

Também neste perfil se encaixa a filosofia de desenvolvimento de computadores portáteis de uso educacional, que teriam baixo custo, assim como capacidade de armazenamento e processamento baixos para os padrões atuais, mas com capacidade de comunicação entre si e através da internet bem desenvolvidos. Como exemplos podemos citar o projeto OLPC (One LapTop Per Child) onde foi criado um protótipo conhecido atualmente como $\mathrm{X} 0$, bem 
como projetos ligados diretamente a empresas tradicionais do ramo tecnológico, como a Intel $\AA$, a Asus $\AA$, a Microsoft ${ }^{\circledR}$ e outras. Em todos estes casos o computador cliente serve apenas como visualizador, sem requerer muito processamento, sendo necessário um computador servidor em cada centro comunitário ou escola para garantir o processamento de determinados programas e o acesso central a internet.

\section{4 - 4M:CHEM}

Em 1994 a expressão "convergência tecnológica" estava relacionada a conjugação, numa mesma tela de computador, de conteúdo em formato de texto e gráfico [GRAZIADEI e McCOMBS, 1995]. Os formatos de leitura e transporte de dados eram feitos por meio do uso de disquetes de tamanhos variados, e a presença do leitor de CD-ROM nos computadores, universalmente aceita e em processo de substituição por leitores de DVD-RW na atualidade, não era pressuposto. Usuários interessados no acesso à informação em formato de CD-ROM deveriam procurar lojas especializadas em equipamentos de informática e arcar com preços pouco populares. O acesso à internet era feito com o uso de protocolos de comunicação mais relacionados aos ambientes UNIX, como telnet, ftp, gopher, lynx, WAIS, e o conceito de navegador hipertexto estava apenas nascendo com 0 antigo Mosaic [ANDREESSEN, 1993]. Os computadores de uso pessoal disponíveis comercialmente no Brasil tinham microprocessador de $100 \mathrm{MHz}$, memória RAM de 16 MB, disco rígido de 100 MB e monitores com resolução VGA (640 x 480).

GRAZIADEI e McCOMBS [1995] arriscam, já nesta época, uma predição de como seria a sala de aula do século 21, onde as mesmas teriam acesso à internet e o principal método de trabalho seria a colaboração de indivíduos em grupos na construção do conhecimento de forma coletiva. Os autores também acreditavam que os navegadores do século 21 importariam os dados num formato bruto para que o usuário pudesse apresentá-lo da maneira que achasse mais conveniente.

Neste contexto, RUSSEL e KOZMA [1994] desenvolveram um ambiente virtual de ensino de química denominado 4M:CHEM onde era possível a visualização simultânea de quatro janelas relacionadas a um mesmo 
experimento. As quatro janelas podiam ser visualizadas individualmente ou em qualquer combinação, em um navegador desenvolvido especialmente para este fim. Quando mais de uma janela era visualizada, as ações em cada uma delas era sincronizada.

A visualização do nível macroscópico se dava por meio de janelas que possibilitavam a visualização de vídeos do experimento, bem como gráficos de propriedades macroscópicas. O programa apresentava 32 diferentes experimentos a respeito de equilíbrios heterogêneos, em solução, no estado gasoso ou sólido. Algumas animações do ambiente permitiam que os estudantes manipulassem as variáveis do sistema, como temperatura e pressão, e observassem imediatamente os resultados da mudança de variável no nível submicroscópico, como o aumento da velocidade e da taxa de colisões das partículas moleculares.

A visualização do nível submicroscópico se dava por meio de uma janela que mostrava animações interativas ou imagens estáticas, ambas acopladas às visualizações dos outros níveis do conhecimento químico. O nível simbólico podia ser visualizado através de imagens estáticas de equações químicas.

De acordo com os autores, a intenção era que os estudantes relacionassem as características superficiais de sistemas em equilíbrio com o efeito das mudanças de variável até que um novo equilíbrio fosse alcançado. Apesar de os estudantes poderem visualizar uma representação animada do sistema em questão, a interação dos estudantes com o ambiente se dava de forma exclusivamente textual. $\mathrm{O}$ ambiente não possuía ferramentas onde $\mathrm{o}$ estudante pudesse criar suas próprias representações.

\section{6 - VisChem}

Em 1996 a integração do áudio e vídeo na sala de aula, através do computador, estava sendo recebida com entusiasmo por parte dos professores e pesquisadores da área de ensino. A idéia de acessar este tipo de informação pela internet não era nem mesmo cogitada devido ao uso massivo de modems de baixa velocidade nos computadores da época, de forma que este tipo de conteúdo era acessado através de mídias e leitores de CD-ROM. Os CD-ROM multimídia haviam sido lançados recentemente naquele ano, e o papel dos 
mesmos no ensino estava crescendo cada vez mais. A presença dos mesmos no computador não era obrigatória nem óbvia. Havia problemas de compatibilidade entre as placas de vídeo e os leitores de CD-ROM, de forma que usuários interessados no uso destas tecnologias deveriam ficar atentos ao comprarem, separadamente no início, o hardware necessário. Nem todas as placas de vídeo e som possibilitavam o uso de leitores de CD-ROM multimídia, e a porcentagem de retorno que vendedores de CD-ROM educativos tinham na época (30\%) era relativamente grande [KIMMEL e DEEK, 1996].

Nesta época já eram utilizadas imagens estáticas representando o nível submicroscópico das representações químicas em formato digital, e as animações que representavam a movimentação relativa entre os átomos e moléculas ainda eram novidade e demandavam boa parte do processamento disponível dos computadores da época. Programas que permitiam o rotacionamento manual de objetos moleculares tridimensionais pelo usuário impressionavam os pesquisadores e profissionais do ensino, e programas computacionais que permitiam tais operações eram restritos e caros. Os arquivos de vídeo tinham tamanho relativamente grande para o acesso por modems (28.8 kbs) e para o armazenamento em discos rígidos, cujo tamanho padrão era em torno de 400 MB, o que limitava a distribuição dos mesmos pela internet e mesmo sua cópia para os computadores. O Mosaic havia se tornado o navegador hipertexto padrão [BROOKS e BROOKS, 1996].

Neste contexto foi desenvolvido o ambiente virtual VisChem [TASKER et al, 1996], o qual mostrava em uma mesma tela do computador os três níveis de representação química, ou seja o macroscópico, o submicroscópico e o simbólico. Este ambiente virtual era acessado por meio do uso de CD-ROM, e utilizava uma janela de navegação desenvolvida especificamente para 0 ambiente. O nível macroscópico podia ser visualizado por meio de clipes de vídeo que mostravam as características superficiais de substâncias ou transformações químicas. O nível simbólico foi representado neste ambiente por meio de imagens estáticas, onde os estudantes podiam visualizar fórmulas e equações químicas.

As animações do nível submicroscópico desenvolvidas neste ambiente virtual representavam partículas moleculares e iônicas em meio aquoso ou em 
estado gasoso. Estas representações foram desenvolvidas para que tivessem como resultado uma comunicação clara, de acordo com os autores, de forma que determinadas características do nível molecular foram modificadas ou mesmo retiradas. As animações foram geradas no formato de "filmes moleculares", obtidas com o uso de programas de simulação por dinâmica molecular. Neste caso as partículas moleculares tiveram sua velocidade reduzida, foram apresentadas no estado gasoso, e não se representava os modos normais de vibração da molécula, com a finalidade de se obter uma comunicação mais clara [TASKER e DALTON, 2006]. Apesar de o ambiente mostrar a movimentação relativa entre os grupos moleculares, os estudantes não tinham a possibilidade de manipular as representações mostradas e nem de criar suas próprias representações.

\section{7 - CHEMMAT}

Em 1997 os cursos a distância eram realizados com o auxilio de fitas de vídeo K-7. JACKSON [1998] fala das vantagens da utilização de imagens estáticas, geradas por computador, nas fitas de vídeo. O uso da internet na época se limitava ao acesso a correio eletrônico, propagandas de cursos no sítio oficial da escola e acesso ao material do aluno. BARRON [1998] fala da dificuldade de uso de plug-in's de visualização para navegadores hipertexto, devido ao tempo de download necessário em modems de $28.8 \mathrm{kbps}$, e à memória necessária para o processamento. Nesta época as telas dos computadores tinham resolução padrão de $640 \times 480$, o que dificultava a visualização de imagens com definições maiores. Os elementos de multimídia que podiam ser visualizados em hipertextos já eram utilizados, mas continuavam sendo um desafio, especialmente os arquivos de vídeo que já eram populares (WAV, AVI e MOV), os quais requeriam tempos de download grandes.

Diante destas possibilidades tecnológicas, TAN e TAN [1997] desenvolveram um ambiente de ensino com o uso da ferramenta de produção de páginas hipertexto Asymetrix Multimedia ToolBook®, onde era possível acessar material multimídia com o uso de navegadores hipertexto. O ambiente virtual foi adaptado para ser acessado através de uma mídia de CD-ROM por 
alunos do Ensino Médio. O formato de transporte e armazenamento de informações através do CD-ROM multimídia estava sendo considerado seriamente por muitas escolas como meio eficaz, já que a possibilidade de múltiplas representações com o uso da capacidade gráfica do computador podia ser explorada em maior extensão. A parte multimídia do ambiente compreendia clipes de vídeo com som e imagem, animações gráficas e imagens fotográficas estáticas. As animações estavam sendo preferidas aos clipes de vídeo em virtude do menor tamanho ocupado. Mesmo os vídeos armazenados em mídias de CD-ROM ficavam relativamente grandes e com baixa qualidade. A intenção dos autores ao produzirem o ambiente virtual CHEMMAT era que o ensino da Química pudesse ser feito de forma mais cativante ao se utilizar imagens estáticas e animadas no ambiente multimídia.

O ambiente também possibilitava a inserção de novos módulos de ensino pelos professores, além dos módulos nativos do ambiente, sem a necessidade de o professor conhecer alguma linguagem de programação. $O$ conteúdo das atividades foi adaptado diretamente de livros texto de Ensino Médio escolhidos pelos autores. Já nesta época os autores vislumbram como trabalho futuro a disponibilização deste ambiente virtual na internet, para acesso dos estudantes e professores.

Neste ambiente virtual o nível macroscópico era visualizado a partir de clipes de vídeo ou de animações, nos quais eram mostrados as próprias substâncias em questão ou os aspectos macroscópicos de experimentos e das transformações químicas. O nível submicroscópico era visualizado com o uso de animações ou figuras estáticas, obtidas com o uso de programas de edição de imagens. Não havia neste ambiente virtual, objetos moleculares tridimensionais que pudessem ser manipulados ou visualizados pelos estudantes. O nível simbólico também era visualizado com o uso de animações e figuras estáticas. As representações das três dimensões do conhecimento químico podiam ser visualizadas de forma conjunta ou separadamente, e não havia ferramenta que possibilitasse a construção de representações por parte dos estudantes. 


\section{8 - ChemViz}

Neste período o navegador hipertexto Internet Explorer ${ }^{\circledR}$ já era amplamente utilizado, e o seu concorrente Netscape ${ }^{\circledR}$ também era bastante conhecido. Neste ano é lançada na internet a ferramenta de busca Google ${ }^{\circledR}$, que se tornaria o padrão de ferramenta de busca, ultrapassando o concorrente Yahoo ${ }^{\circledR}$ em poucos anos.

Neste contexto BECKWITH e NELSON [1998] desenvolveram o ambiente virtual conhecido como ChemViz, o qual combina um conjunto de ferramentas de visualização e edição de objetos moleculares com seqüências de ensino acessíveis com o uso de navegadores hipertexto. $\mathrm{O}$ ambiente também exige a instalação prévia do ambiente Java ${ }^{\circledR}$. O ambiente virtual ChemViz foi desenvolvido com vistas a tornar a química computacional acessível a estudantes de ensino médio e superior. Todas as ferramentas do ambiente privilegiam as visualizações das representações submicroscópica e simbólica do conhecimento químico simultaneamente.

Uma das ferramentas (Waltz), é uma interface de acesso pela internet para um programa instalado em um computador servidor (DiSCO), o qual calcula densidades eletrônicas e orbitais moleculares. Através desta interface os estudantes realizam atividades de ensino sobre conceitos abstratos como elétrons, átomos, moléculas e ligações químicas.

Uma segunda ferramenta do ambiente permite que os estudantes se conectem a um banco de dados de estruturas cristalográficas pela internet, os quais podem procurar estruturas como aspirina, etanol ou cafeína pelo nome ou fórmula. Em todos os casos o estudante obtém como resposta um objeto molecular tridimensional se tiver o plug-in MDL-Chime ${ }^{\circledR}$ instalado em seu computador.

O ambiente oferece a possibilidade de acesso às seqüências de ensino através de navegadores hipertexto, e possui uma ferramenta de construção de objetos moleculares tridimensionais. Esta ferramenta, no entanto, exige conhecimentos sobre estruturas moleculares que vão além dos objetivos do Ensino Médio, como campos de força e otimização de geometria. Há também a possibilidade de instalação de todas as ferramentas do ambiente para uso sem o acesso a internet. Esta opção requer, no entanto, a instalação de pacotes de 
programas, como Gamess ${ }^{\circledR}$, Molden $®$, e os plug-ins Cortona ${ }^{\circledR}(\mathrm{VRML})$ e MDLChime ${ }^{\circledR}$, além do ambiente Java ${ }^{\circledR}$, o que exige conhecimentos aprofundados do usuário. O ambiente não possui visualizações do nível macroscópico do conhecimento químico.

\section{0 - SMV:Chem}

Neste ano o potencial financeiro da internet se torna patente com 0 anúncio da fusão entre a Time Warner®, uma gigante da mídia, e a America OnLine ${ }^{\circledR}(A O L)$, um importante portal de conteúdo na internet. Um software de compartilhamento de músicas pela internet conhecido como Napster ${ }^{\circledR}$ havia sido lançado no mesmo ano e começava a atrair a atenção de grandes produtoras musicais norte-americanas. O navegador Internet Explorer ${ }^{\circledR}$ já era considerado como o padrão de navegadores hipertexto, e tocadores de música de variados formatos de arquivo e baixados gratuitamente da internet disputavam a atenção dos usuários. Processadores com velocidade de $1 \mathrm{GHz}$ de velocidade de processador, memória RAM de $512 \mathrm{MB}$, discos rígidos de 20 GB e monitores com resolução SVGA (800 x 600) começavam a entrar no mercado de computadores de uso pessoal no Brasil.

Em 1999 as ferramentas de visualização da modelagem molecular eram populares apenas entre os estudantes de pós-graduação e pesquisadores da área de Química Teórica. EALY [1999] faz um estudo sobre o uso destas ferramentas para estudantes de graduação e obtém melhoras na compreensão dos estudantes sobre a natureza particulada da matéria. O grande avanço, segundo a autora, foi trazer estas ferramentas de visualização para alunos de graduação, os quais utilizaram o software Spartan ${ }^{\circledR}$ em computadores Silicon Graphics ${ }$ em ambiente UNIX®. De acordo com o estudo realizado, a visualização é a principal característica distintiva no uso de computadores na química nas respostas abertas dadas pelos estudantes.

COLLIS [1999] descreve que a partir desta data os ambientes virtuais passaram a dar suporte aos cursos a distância, de forma que anteriormente 0 acesso a internet apenas oferecia informações sobre o curso ou sobre assunto específicos de matrícula e mensalidade. O objetivo da mudança era aumentar a eficiência do envio do curso, feito exclusivamente pelo correio até então, bem 
como a eficiência na participação dos alunos, uma vez que o acesso a internet nos Estados Unidos da América estava em um estágio bastante avançado.

Neste contexto KOZMA e colaboradores [2000] desenvolveram o ambiente virtual denominado SMV:Chem a partir do software 4M:Chem [RUSSEL e KOZMA, 1994]. Este ambiente virtual foi concebido com a intenção de mostrar experimentos que ilustram conceitos considerados chave dentro do conhecimento químico, usando animações em escala molecular, gráficos, modelos moleculares e equações. Da mesma forma que seu predecessor, este ambiente virtual disponibilizava para o usuário quatro janelas mostrando cada um dos aspectos macroscópicos, submicroscópicos e simbólicos do experimento, de forma que cada uma das quatro janelas podia ser vistas de forma independente ou em qualquer combinação.

O nível macroscópico era visualizado na janela superior esquerda por meio de um clipe de vídeo mostrando a realização do experimento. No entanto, nesta última versão, a demonstração era acompanhada por uma narrativa do experimento. Existiam também clipes de áudio separados para as outras três janelas que podiam ser ativadas quando a janela era vista de forma separada. O nível submicroscópico podia ser visualizado na janela superior direita por meio de animações bidimensionais, as quais permitiam que o usuário apenas assistisse à animação sem poder interagir com as mesmas. O nível simbólico podia ser visualizado por meio de figuras estáticas mostrando fórmulas e equações na janela inferior direita, e também por meio de animações com gráficos cartesianos bidimensionais que mostravam a variação de propriedades macroscópicas, como temperatura, na janela inferior esquerda.

Este ambiente virtual era utilizado a partir da instalação de uma mídia de CD-ROM adquirida de forma comercial, e havia uma janela de navegação, desenvolvida para o próprio ambiente, que possibilitava o acesso às atividades de ensino. Não existia a possibilidade de os estudantes criarem suas próprias representações, nem manipularem as estruturas moleculares veiculadas.

\section{1 - eChem}

Neste ano, foi lançado comercialmente o sistema operacional Windows $X P ®$, o qual se tornaria o novo padrão de sistemas operacionais para 
computadores pessoais do tipo IBM-PC nos próximos sete anos, onde aplicativos de edição de texto, planilhas e imagens podem ser facilmente manuseados mesmo por usuários iniciantes. A disponibilidade deste sistema operacional por um tempo relativamente maior entre usuários, a despeito das inúmeras correções de segurança, e a relativamente alta disponibilidade de informação em livros e na internet, auxiliou a proliferação do desenvolvimento de editores e tocadores dos mais diversos tipos de mídia.

Neste contexto WU, KRAJCIK e SOLOWAY [2001] utilizaram uma versão simplificada de ferramentas profissionais denominada eChem, desenvolvida na Universidade de Michigan, para auxiliar estudantes de Ensino Médio na construção e visualização de múltiplos modelos tridimensionais, bem como na comparação com representações macroscópicas. O acesso ao ambiente era feito através de uma interface gráfica construída especificamente para o mesmo, o qual devia ser instalado previamente ao uso. Ao invés de oferecer modelos construídos prontos o ambiente possibilitava a construção dos modelos por parte dos estudantes, os quais podiam, desta forma, externalizar seu conhecimento.

O ambiente era composto por três interfaces distintas, que privilegiavam a visualização e manipulação de representações do nível submicroscópico. No módulo de construção, os estudantes podiam criar moléculas orgânicas a partir de uma tabela periódica simplificada, bem como manipular o objeto molecular resultante através de rotações e translações. Nesta área do ambiente virtual, as moléculas deviam ser construídas átomo por átomo e ligação por ligação, sendo que o tipo de ligação deveria ser especificado como simples, dupla ou tripla. No módulo de visualização os estudantes podiam visualizar diversos formatos que representavam a molécula construída, tais como modelos espaço preenchido e bola-vareta. No módulo de análise os estudantes podiam fazer conexões entre os modelos moleculares visualizados e o comportamento coletivo das partículas, que resultavam em propriedades físico-químicas macroscópicas. Esta era a única opção de visualização das representações macroscópicas.

Este ambiente virtual não oferecia a possibilidade de visualização de representações simbólicas da molécula, e também não possibilitava a 
visualização da movimentação relativa entre os átomos, de forma que os estudantes não tinham acesso à visualização de propriedades dinâmicas das moléculas.

\section{2 - ChemSense}

Neste ano a recém lançada Wikipedia, uma enciclopédia virtual que pode ser editada de forma colaborativa, contava com 30.000 entradas, sendo 90\% delas em inglês, e chega à marca de 1.75 bilhões de entradas em 2007 em 250 diferentes línguas ${ }^{1}$, com menos da metade das entradas na língua inglesa.

Neste contexto, o ambiente virtual conhecido como ChemSense foi desenvolvido para ser utilizado por estudantes de Ensino Médio em conjunto com aulas de laboratório [SCHANK e KOZMA, 2002; MAYER, 2005]. O ambiente dispõe de um aplicativo Java ${ }^{\circledR}$ desenvolvido para ser executado em navegadores hipertexto, o qual possibilita a criação e a análise de animações bidimensionais e gráficos cartesianos. Neste ambiente os estudantes podem visualizar representações dos níveis submicroscópico e simbólico do conhecimento químico.

A interface gráfica com o usuário apresenta uma tela dividida em quatro janelas, as quais contêm as quatro ferramentas básicas de desenho, animação, gráficos cartesianos e texto. As quatro ferramentas são disponibilizadas de forma simultânea e uma quinta ferramenta de acesso a internet, chamada de ChemSense Gallery, possibilita a visualização e a adição de comentários sobre os trabalhos realizados e o gerenciamento de contas e grupos. Os níveis submicroscópico e simbólico podem ser visualizados e manipulados pelos estudantes nas janelas de desenho e animação, nos quais constroem suas próprias representações.

Para criar as animações os estudantes constroem individualmente cada quadro utilizando a ferramenta de desenho, a qual disponibiliza ao estudante figuras geométricas e outras ferramentas de representação de estruturas orgânicas. Com esta ferramenta os estudantes podem, por exemplo, desenhar as etapas de uma transformação química, de forma que a visualização

1. http://en.wikipedia.org/wiki/History of_Wikipedia. Acessado em 10/09/07. 
seqüencial dos quadros resulta em uma impressão de movimentação das figuras na forma de uma animação que pode ser vista em outra janela.

$\mathrm{Na}$ janela inferior esquerda se encontra a ferramenta de construção e visualização de gráficos cartesianos, com dados coletados pelos próprios estudantes em experimento realizado no laboratório úmido. O ambiente possui uma ferramenta que possibilita o exercício dos aspectos do trabalho colaborativo entre estudantes. $\mathrm{Na}$ janela inferior direita existe uma área onde os estudantes podem visualizar e postar para seu grupo os comentários e questões sobre o experimento, sendo que cada estudante também dispõe de espaço para comentários pessoais.

As atividades de ensino propostas no ambiente virtual deve ser executadas em conjunto com as atividades de um laboratório úmido de química, ao invés de simplesmente assistirem um vídeo de experimentos realizados por outros. O discurso dos estudantes fica registrado na forma de anotações, as quais podem ser resgatas pelos próprios estudantes e pelo professor. Além disso, as atividades de ensino foram elaboradas para que os estudantes trabalhem de forma colaborativa na investigação, análise e discussão dos temas propostos. O ambiente não possibilita a criação, visualização ou manipulação de objetos tridimensionais.

\section{2 - ChemDiscovery}

O ambiente virtual de nome ChemDiscovery [AGAPOVA et al., 2002] é composto por um conjunto de animações sobre variados tópicos da química adaptados em páginas hipertexto acessíveis através de navegadores comuns, junto com ferramentas de construção de representações moleculares, as quais devem ser previamente instaladas no computador a ser usado pelo estudante. As atividades de ensino adaptadas para o ambiente permitem que a instrução esteja centrada no aluno em uma modalidade de ensino chamada de inquiry-oriented.

O nível macroscópico do conhecimento químico pode ser visualizado nas animações bidimensionais e em figuras estáticas inseridas nas páginas hipertexto, as quais apresentam as características macroscópicas de substâncias e transformações químicas. O nível submicroscópico pode ser 
visualizado e as representações podem ser manipuladas em uma ferramenta de construção de objetos moleculares e orbitais, onde os próprios estudantes podem construir novas representações. O nível simbólico pode ser visualizado por meio de figuras estáticas de estruturas e transformações químicas, também inseridos nas páginas hipertexto.

As atividades deste ambiente virtual encorajam os estudantes a trabalhar em grupos reduzidos ou duplas, e favorecem o questionamento dos significados sobre os temas propostos em cada etapa das atividades realizadas. Além das animações e dos textos que as acompanham, o ambiente fornece uma área de navegação dentro do ambiente e de cada atividade. $O$ ambiente não oferece a possibilidade de o estudante inserir suas respostas no ambiente, uma vez que o mesmo é acessado através de mídias de CD-ROM.

\section{3 - CHEMnet}

Neste ano o primeiro decreto presidencial é assinado nos Estados Unidos da América criando leis sobre mensagens eletrônicas não solicitadas, mais conhecidos como SPAM's, que correspondiam à metade destas mensagens circulantes na internet naquele momento ${ }^{1}$.

O ambiente virtual denominado CHEMnet [NICK et al., 2003] foi o primeiro desenvolvido para o ensino de química em linguagem HTML, o qual podia ser acessado exclusivamente pela internet com o uso de navegadores hipertexto. O acesso a este ambiente não requeria o uso de CD-ROM's, de forma que qualquer ferramenta necessária para a utilização dos recursos do ambiente, como tocadores de diferentes tipos de mídias, podiam ser obtidas diretamente da internet. As atividades de ensino do ambiente em formato multimídia podiam ser utilizadas para Ensino Médio ou Superior. O ambiente continha mais de 2300 páginas hipertexto, 140 vídeos e 60 animações e simulações que podiam ser acessadas através de navegadores hipertexto em computadores com acesso à internet. Na construção do ambiente também foi utilizada a linguagem VRML, assim como arquivos de vídeo e animações em vários formatos mostrando experimentos de laboratório. $\mathrm{O}$ acesso ao ambiente era gratuito, sendo exigido o registro do usuário no primeiro acesso. Os

1. http://www.spam.com/legal/spam/. Acessado em 10/09/07. 
acessos de todos os usuários eram gravados em arquivos de log no computador servidor, de forma que existia um acompanhamento de cada usuário para fins estatísticos. O acesso principal ao ambiente era composto por um texto principal onde as atividades de ensino e os arquivos multimídia estavam inseridos, além de barras de navegação principal e secundária que facilitavam a navegação tanto nas atividades quanto no ambiente como um todo.

De acordo com os resultados do estudo apresentado pelos autores, metade dos usuários (4850) que se cadastraram para usar o ambiente no período de 2000 a 2003 nunca havia entrado em contato com materiais multimídia de química, como vídeos, e simulações tridimensionais. Os usuários utilizaram o ambiente também como manual de consulta, o que foi observado através dos cerca de 13000 impressões de páginas, contando somente as que foram impressas utilizando a própria ferramenta de impressão do ambiente.

Neste ambiente, o nível macroscópico das representações químicas podia ser visualizado por meio de clipes de vídeo e animações, os quais não oferecem possibilidade de interação com o usuário. O nível submicroscópico podia ser visualizado por meio de figuras estáticas, animações e objetos moleculares tridimensionais em dois formatos: a linguagem de realidade virtual VRML e o plug-in MDL-Chime ${ }^{\circledR}$. A inserção destes objetos moleculares tridimensionais no ambiente possibilitou a manipulação e visualização dos mesmos por parte dos usuários. O nível simbólico do conhecimento químico podia ser visualizado com o uso de imagens estáticas e animações bidimensionais, os quais também não ofereciam possibilidade de interação com o usuário. Infelizmente não havia ferramentas no ambiente que possibilitassem que os usuários gerassem suas próprias representações.

\section{3 - Connected Chemistry}

O ambiente virtual de nome Connected Chemistry foi escrito na linguagem de modelagem multiagente (MAML) e procura explorar o conceito de equilíbrio químico [STIEFF e WILENSKY, 2003]. O ambiente desenvolvido disponibiliza vários modelos pré-construídos com regras subjacentes, as quais podem ser acessadas por estudantes e professores, que podem por sua vez 
mudá-las ou desenvolver novos modelos pré-construídos. Cada modelo simula um sistema químico fechado, com os quais os estudantes podem interagir através da modificação de parâmetros pré-selecionados. A parte principal do ambiente consiste numa janela de interface gráfica com o usuário dividida em um ambiente de visualização de partículas tipo "caixa de vidro", e outro ambiente com as variáveis do sistema, como temperatura, pressão ou concentração, manipuláveis por meio de botões e barras de rolagem.

Neste ambiente virtual, a visualização do nível submicroscópico ocorre por meio de uma "caixa" de partículas, gerada sob demanda a partir de regras de simulação molecular, ao contrário de outros ambientes virtuais que mostram filmes e animações pré-construídas aos estudantes. O ambiente não oferece a possibilidade de visualizar ou manipular objetos moleculares, mas apenas grupos de partículas, e também não é possível visualizar o mesmo sistema a partir de mais de um ponto de vista simultaneamente. Não é possível utilizar o mouse para a manipulação do grupo de partículas, mas apenas das propriedades.

A visualização do nível macroscópico ocorre através de uma janela que mostra um gráfico cartesiano das modificações das variáveis em função das mudanças impostas ao sistema, como por exemplo, as mudanças de concentração dos produtos após aumento ou diminuição de temperatura. Com isso as visualizações dos níveis submicroscópico e macroscópico estão associadas, de forma que as modificações nos parâmetros da simulação podem ser vistos em ambos os níveis de representação. Não existe opção de visualização do nível simbólico do conhecimento químico. O ambiente deve ser instalado e executado em cada computador onde for utilizado, não sendo possível utilização pela internet.

\section{4 - Chemical Change}

O padrão de visualização dos monitores passa a ser de 1024 X 768 em função da maior disponibilidade e menor preço de placas de processamento gráfico de maior capacidade, e o conceito de convergência digital tem como significado a convergência e integração de padrões de comunicação, como o telefone celular e televisão, com a internet. Microprocessadores com 
arquitetura de 64 bits e dois núcleos começam a ser produzidos pela $A M D \circledast$, e o sítio de comunidades virtuais conhecido como Orkut ${ }^{\circledR}$ é lançado pelo Google ${ }^{\circledR}$. Impressoras que podem ser compradas a baixos preços de mercado no Brasil, como a Lexmark ${ }^{\circledR}$ E232, já vêm equipadas com microprocessadores de $200 \mathrm{MHz}$ e memória virtual de $16 \mathrm{MB}$, o que era considerado um microcomputador padrão há menos de uma década atrás. Neste ano também é lançado na internet o navegador Firefox ${ }^{\circledR}$, com código fonte aberto e download gratuito, que logo passa a ser o segundo navegador hipertexto mais utilizado.

Diante deste quadro, ARDAC e AKAYGUN [2004 e 2005] desenvolveram um ambiente virtual de visualização química (Chemical Change), o qual enfatiza as representações macroscópicas, simbólicas e submicroscópicas das transformações químicas. Este ambiente foi desenvolvido com o auxílio da ferramenta ToolBook 7 ® que é uma ferramenta de criação e edição de aplicações hipertexto. No ambiente virtual existe a integração de elementos visuais e interativos com os elementos hipertexto que compõem as atividades de ensino. Através do uso de animações, clipes de vídeo, figuras estáticas e áreas de edição de imagens, o software oferece os três tipos de representação simultaneamente aos estudantes.

Como visualização do nível macroscópico, o ambiente virtual dispõe de clipes de vídeo, na maioria das vezes, os quais mostram as características superficiais deste nível de representação. Com isso, não existe a possibilidade de os estudantes interagirem com estas representações. Para o nível submicroscópico, o ambiente disponibiliza representações no formato de figuras estáticas e animações obtidas do ambiente virtual VisChem [TASKER et al., 1996]. O ambiente não conta com ferramentas que possibilitem a criação ou visualização de objetos moleculares. No nível simbólico, o ambiente fornece apenas representações no formato de figuras estáticas, de forma que o estudante também não pode interagir com as mesmas.

Neste ambiente virtual, são propostas atividades de ensino nas quais é necessário que os estudantes interajam com material de suporte instrucional apostilado, de forma que os mesmos são solicitados a apresentar desenhos e respostas escritas como resultado final. 


\section{4 - Molecular Workbench}

O ambiente virtual conhecido como Molecular Workbench $®$ foi desenvolvido pelo Concord Consortium ${ }^{1}$ para estudantes de ensino médio. Para a utilização das ferramentas deste ambiente foi desenvolvido um navegador especialmente para este fim na linguagem Java ${ }^{\circledR}$, o qual deve ser instalado com antecedência e também pode ser utilizado como navegador hipertexto [PALLANT e TINKER, 2004].

O desenvolvimento do ambiente está baseado em um aplicativo de dinâmica molecular, executado do lado do computador cliente. Os modelos a serem visualizados e manipulados devem ser baixados do sítio servidor de arquivos, o qual pode então ser executado em cada máquina. O computador em uso pelo estudante gera uma visualização tridimensional de moléculas e de outras estruturas submicroscópicas ou macroscópicas a partir de regras de simulação obtidas pela internet, chamadas de modelos, as quais podem ser vistas e manipuladas com o uso do mouse. Com isso o ambiente possibilita a visualização dos níveis macroscópico, submicroscópico e simbólico por parte dos estudantes, dependendo apenas do modelo que foi baixado e será explorado.

Para o desenvolvimento de novas seqüências de ensino é necessário aprender a linguagem de programação do ambiente Pedagógica ${ }^{\circledR}$, desenvolvida pelo mesmo grupo, e a linguagem JavaScript $\AA$, o que restringe severamente 0 desenvolvimento de novas seqüências de ensino, especialmente por parte de professores.

As ferramentas no ambiente possibilitam a manipulação de objetos moleculares tridimensionais, bem como a criação de filmes a partir dos mesmos. No entanto os estudantes têm acesso apenas aos objetos moleculares disponibilizados no sistema e às ferramentas disponibilizadas em cada modelo, não sendo possível a criação de novas estruturas por parte estudantes [XIE e TINKER, 2005].

1 http://workbench.concord.org. Acessado em 12/10/2007. 


\subsection{2 - Considerações sobre os dados da revisão bibliográfica}

Alguns dos ambientes virtuais desenvolvidos para o Ensino de Química, descritos até o momento, possibilitam a visualização de imagens estáticas ou animadas das três dimensões do conhecimento químico, onde não é possível a interação com o usuário, ou é possível apenas de forma textual, como no caso de VisChem e 4M:Chem.

Quando é possível a manipulação de objetos moleculares tridimensionais, o estudante não pode criar suas próprias estruturas moleculares, podendo apenas procurar estruturas em um banco de dados de um CD-ROM ou na internet, como no ambiente ChemNet. Além disso, não é possível que o estudante faça suas próprias investigações sobre a relação entre a representação simbólica e a representação submicroscópica, uma vez que não existe nenhuma ferramenta onde se possa comparar estas duas formas de representação.

Nos ambientes virtuais existentes até o momento também não existe a possibilidade de visualização da movimentação relativa entre os átomos, a qual revela importantes propriedades da matéria em escala submicroscópica, tanto nos aspectos cinéticos quanto termodinâmicos das partículas atômicas e moleculares.

Em casos de ambientes virtuais em que o estudante pode criar suas próprias representações animadas, como no caso do Molecular Workbench, as mesmas são bidimensionais e obtidas a partir de um programa comum de edição de imagens. A despeito da importância de estudantes desempenharem este tipo de atividade, quando não há um acompanhamento adequado os mesmos podem criar representações que não estão em acordo com o conhecimento químico oficialmente aceito na atualidade, o que pode resultar em graves erros conceituais.

Diante disto faz-se necessário o desenvolvimento de um novo ambiente virtual de ensino de química, onde estudantes iniciantes em Química, do Ensino Médio ou Superior, possam criar seus próprios objetos moleculares tridimensionais a partir de ferramentas simplificadas, a partir da representação simbólica bidimensional, de forma que estas duas dimensões do conhecimento químico, simbólica e submicroscópica, possam ser correlacionadas de forma 
apropriada em atividades de ensino.

Desenvolvemos neste trabalho um ambiente virtual de ensino de química onde as representações próprias do conhecimento químico têm papel primordial, em especial a relação entre as dimensões submicroscópica e simbólica. Para uma discussão pormenorizada deste ambiente virtual, é necessário considerar o papel das representações no conhecimento químico, bem como a contribuição gráfica e de processamento dos computadores para a visualização destas representações. A partir disso levantamos na próxima seção uma discussão a respeito da importância das representações químicas na composição desta área de conhecimento, dando ênfase à contribuição que as representações viabilizadas pelo avanço do desenvolvimento dos computadores podem trazer para a sala de aula de Química. É necessário também lançar mão de uma base teórica que considere explicitamente o papel dos signos, ou representações, no conhecimento humano, o que será feito no Capítulo 2.

\section{8 - Objetivos de pesquisa}

Temos como objetivo de pesquisa descrever as etapas de desenvolvimento do aplicativo computacional Construtor, a partir do qual estudantes de Ensino Médio podem construir objetos moleculares virtuais tridimensionais a partir unicamente da fórmula estrutural condensada de espécies químicas. Este aplicativo computacional foi adaptado em uma seqüência de ensino acessível pela internet através de navegadores hipertexto, o que resultou em um ambiente virtual de ensino de química.

Também temos como objetivo de pesquisa descrever a avaliação do uso do ambiente virtual descrito neste trabalho. Esta avaliação de uso será feita por intermédio de dados obtidos com um sistema de captura sincronizada de vídeo, através do qual é possível gravar em arquivos de vídeo, de forma simultânea, a tela em uso pelo estudante e suas ações diante do computador, sendo os arquivos gravados no próprio computador em uso pelo estudante. Desta forma é possível minimizar a introdução de equipamentos estranhos à aula durante o teste de usabilidade do sistema. 
O sistema de captura sincronizada de vídeo e o aplicativo computacional Construtor foram adaptados a uma seqüência de ensino, o que constituiu o ambiente virtual de ensino de química discutido neste trabalho. Este sistema foi utilizado por duas turmas de Ensino Médio de uma escola da Rede Pública Estadual de São Paulo em dois diferentes anos, e os resultados estão descritos no Capítulo 4 deste trabalho. As atividades de ensino propostas no ambiente virtual privilegiam um formato colaborativo de trabalho, de forma que os estudantes são solicitados a trabalhar em duplas para a realização das atividades.

No próximo capítulo farei uma reflexão sobre a teoria dos signos, a qual auxilia na compreensão das questões relativas às formas de representação das três dimensões do conhecimento químico, e também no desenvolvimento e uso do aplicativo em sala de aula. 


\section{2 - REFERENCIAIS TEÓRICOS}

\section{1 - Conhecimento e mediação}

Pesquisas no campo da psicologia cognitiva, da epistemologia e da sociologia da ciência trouxeram a luz o fato de que o conhecimento não é apenas uma elaboração pessoal, mas também uma elaboração situada histórica e socialmente. A importância da linguagem na constituição do pensamento tem sido amplamente debatida nos meios acadêmicos. Uma corrente que emerge destes questionamentos é a teoria sócio-histórica ou histórico-cultural de Lev Semenovich Vigotski e seus colaboradores, bem como os desdobramentos de sua obra. Esta linha de pesquisa traz os fatores sociais para dentro da relação de desenvolvimento da aprendizagem e do sujeito. De acordo com Vigotski, as ferramentas que utilizamos moldam nossa experiência $\mathrm{e}$, conseqüentemente, nosso pensamento.

Vigotski transitou por diversas áreas do conhecimento como direito, ciências sociais, medicina e psicologia. Também atuou de forma diversificada, mas sempre com trabalhos voltados para a área intelectual. $O$ interesse pela psicologia o levou a uma busca da compreensão dos processos mentais humanos. "Deteve-se no estudo dos mecanismos psicológicos mais sofisticados (as chamadas funções psicológicas superiores), típicos da espécie humana: o controle consciente do comportamento, atenção e lembrança voluntária, memorização ativa, pensamento abstrato, raciocínio dedutivo, capacidade de planejamento, etc" [REGO, 1995, p.24]. Seu trabalho contou com grande participação de dois pesquisadores, Luria e Leontiev. Vigotski morreu em 1934 e suas obras no Brasil foram conhecidas somente 50 anos mais tarde. Dentro de sua extensa contribuição para o ensino elucidamos a importância não somente dos fatores relacionados à aprendizagem, mas também sociais, culturais e históricos. A escola seria um ambiente desafiador onde são desenvolvidas atividades complexas possibilitando novas formas de pensamento. "Como conseqüência, na medida em que a criança expande seus conhecimentos, modifica sua relação cognitiva como o mundo" [REGO, 1995, p.104]. 
Uma das principais contribuições de Vigotski para a psicologia do desenvolvimento é a noção de mediação da ação do sujeito sobre os objetos. Desta forma, as funções mentais superiores e a ação humana em geral são mediadas por ferramentas técnicas e ferramentas psicológicas, ou ferramentas culturais na concepção da ação mediada [WERTSCH, 1998]. A partir disso, na perspectiva da teoria da ação mediada, as ações humanas, sejam elas externas - entre indivíduos - ou internas - no plano mental - são mediadas por ferramentas culturais que estruturam as ações e as determinam.

Quando se trata da organização do ensino, a teoria da ação mediada coloca em destaque a fala como principal mediador das atividades da sala de aula. É através da fala que o professor propõe e executa as atividades, expondo idéias, conduzindo ou coordenando tarefas, apresentando o plano de aulas e o caminho já percorrido. Na sala de aula, a fala é o principal instrumento de organização das atividades de ensino, não apenas por medialas, mas fundamentalmente por servir de suporte à construção do pensamento, constituindo-se como principal ferramenta para estruturar e constituir as atividades de ensino.

A partir dos estudos literários e lingüísticos de Bakhtin, Wertsch adota a noção de dialogia, que compõe parte de um dispositivo analítico para estudar a ação mediada, e também a noção de apropriação (1981), relativo ao processo de tomar algo de outro e torná-lo seu, próprio. "No sistema de Bakhtin, todos nós somos estranhos uns aos outros. Por definição: cada um de nós tem a sua própria linguagem, ponto de vista, sistema conceitual que para outros é estranho. Ser estranho torna o diálogo possível“ [WERTSCH, 1998, p. 53-4]. Bakhtin concebe a linguagem em meio à necessária e sempre presente, tensão entre o próprio e o estranho, na fronteira entre o eu e o outro. Um exemplo de ferramenta cultural indicada por Wertsch como bastante significativa para compreender as representações do passado é a narrativa. De fato, se tomarmos as atividades de ensino como eventos situados e deflagrados por narrativas que recuperam as ações anteriores e organizam ações dos alunos na sala de aula, é razoável considerar que a estruturação das ações nos cenários da sala de aula, é condicionada pela narrativa e suas especificidades, como, por exemplo, intertextualidade, contextualização e gêneros discursivos. 
Ainda sobre o papel da narrativa na organização da atividade mental, Bakhtin afirma: "O centro organizador e formador não se situa no interior, mas sim no exterior. Não é a atividade mental que organiza a expressão, mas, ao contrário, é a expressão que organiza a atividade mental, que modela e determina a sua orientação", [BAKHTIN, 1981]. O exercício desta importante ferramenta cultural com o intuito do compartilhamento de significados pode se constituir num forte instrumento de promoção do aprendizado.

Neste trabalho descrevemos o desenvolvimento de uma ambiente virtual para estudo sobre representações químicas. Neste ambiente o papel da narrativa se encontra presente na estrutura do módulo de ensino, elaborado anteriormente [ANJOS, 2004] e adaptado por nós para este trabalho, como um possibilitador da convergência de mídias disponíveis para o ensino da química [GIORDAN, 2005]. Além disso a constituição da narrativa dos estudantes, presentes em modelos explicativos produzidos pelos mesmos, é importante para o estudo deste ambiente virtual de ensino.

O ambiente virtual desenvolvido neste trabalho privilegia o papel da mediação através da fala e das diferentes formas de representação do conhecimento químico.

Os símbolos próprios da Química, de forma grafada e oral, têm um importante papel no aprendizado desta área de conhecimento. Trazemos a seguir uma discussão a respeito da contribuição da teoria dos signos de Charles Sanders Peirce para a compreensão do papel das diferentes representações dos níveis macroscópico, submicroscópico e simbólico no conhecimento químico.

\section{2 - Teoria dos signos}

A utilização apropriada de simbologias desenvolvidas ao longo de séculos constitui uma parte significativa do conhecimento químico, por ser uma ciência que trata da matéria em uma escala submicroscópica, ou nanoscópica, conforme visto no Capítulo 1 deste trabalho.

A despeito da importância do uso apropriado das simbologias químicas no âmbito da sala de aula de química, é freqüente a dificuldade por parte de 
estudantes sobre a compreensão e uso destes símbolos, o que é apoiado pelo estudo das concepções alternativas de estudantes de Ensino Médio e Superior.

No sentido de compreender as relações de significação de representações próprias grafadas e faladas que tem lugar na sala de aula de química, descrevemos neste capítulo as bases da teoria semiótica de Charles Peirce e sua contribuição para a compreensão dos processos de significação deste ambiente de ensino. Esta teoria trata explicitamente a relação entre as representações e seus "motores de significação", o que é importante para a compreensão dos processos de ensino e aprendizagem que ocorrem em atividades de ensino na sala de aula de química.

Temos como objetivo neste texto trazer uma compreensão mais aprofundada a respeito dos processos de significação de representações químicas na sala de aula a partir da contribuição da teoria semiótica de Peirce. Também temos como objetivo discutir a contribuição das representações computacionais nos processos de significação na sala de aula de química. Com esta reflexão queremos, portanto, amparar o desenvolvimento de ambientes virtuais de ensino de química em base teórica que nos permita conjugar aspectos epistemológicos da Química com os fundamentos da teoria dos signos na direção de problematizar a produção de significados na sala de aula.

\subsection{1 - Peirce: uma breve biografia}

Charles Sanders Peirce (1839-1914) nasceu em Cambridge, Massachusetts, e é considerado o mais importante dos fundadores da moderna teoria geral da semiótica [NÖTH, 2005]. Seus escritos têm recebido atenção internacional por mais de um século, e contribuíram substancialmente para a base do pensamento científico moderno [PEIRCE, 1981]. Seu pai, Benjamin Peirce, foi um distinto professor de matemática na Universidade de Harvard, sendo considerado o mais importante matemático norte-americano em sua época. Sua família mantinha proximidade dos círculos acadêmicos e científicos, e em sua casa eram recebidos os mais renomados artistas e cientistas, de forma que desde criança Peirce já convivia num ambiente de natural inclinação intelectual. Tinha aspirações ao conhecimento químico desde 
os seis anos de idade e aos onze anos escreveu uma pequena história da Química.

Por influência de seu pai se bacharelou em Física e Matemática na Universidade de Harvard em 1859, e se graduou em Química com a qualificação summa cum laude (aprovado com louvor) na Lawrence Scientific School em 1863 [SEBEOK e SEBEOK, 1987]. Peirce se considerou químico por muito tempo durante sua vida, mesmo quando sua busca científica o levou para outras áreas do conhecimento [PEIRCE, 1981]. Além da Química, Peirce tinha interesse em várias outras áreas do conhecimento, como Matemática, Física, Astronomia, Biologia, Economia, Geodésica, Topografia, Cartografia, Lingüística, Filologia, História, Arquitetura, Artes Plásticas, Quirografia, Línguas (conhecia cerca de dez), Psicologia, e era um profundo conhecedor de Literatura. Trabalhou durante a maior parte de sua vida profissional a serviço do governo federal em Astronomia e Geodésica durante o dia e, de 1861 a 1891, no observatório da Universidade de Harvard durante a noite [SANTAELLA, 2005]. O centro de todo o interesse de Peirce era a Lógica, que ele considerava ser apenas um outro nome da Semiótica. Conforme veremos abaixo, sua formação básica e inicial em Química provavelmente contribuiu de maneira substancial para o desenvolvimento de sua teoria semiótica.

\subsection{2 - O que é a semiótica?}

A semiótica é a ciência dos processos significativos (semiose), dos signos lingüísticos e das linguagens [NÖTH, 2005]. Estes processos significativos são mediados pela materialidade da palavra grafada ou falada, de símbolos escritos, gestuais ou naturais, e acontecem sempre que alguma coisa significa algo para alguém [PEIRCE, 2005, pp. 61]. Desta forma, além de ser necessário que haja uma veiculação material do signo, é necessário também que o mesmo seja percebido e compreendido por um ser vivo.

Esta ciência propriamente dita teve o seu inicio com o filósofo John Locke (1632-1704), que postulou uma "doutrina dos signos" com o nome de Semeiotiké, em 1690 na sua obra Essay on human understanding [NÖTH, 2005]. Charles Sanders Peirce, no entanto, deu a contribuição de maior peso 
para esta ciência que foi a última ciência humana a ser estabelecida como área de conhecimento no início do século XX.

A semiótica, que também tem por objeto de estudo todas as linguagens possíveis [SANTAELLA, 2005], traz importantes contribuições para o entendimento do papel da linguagem nas ações humanas. Neste ponto não se deve confundir linguagem com língua. Por língua pode-se entender a língua nativa, materna ou pátria, utilizada cotidianamente para a comunicação de forma escrita e oral. Mas esta comunicação também pode acontecer por intermédio de outras linguagens, como imagens, gráficos, sinais, luzes, fenômenos naturais, através do cheiro e do tato, e muitas outras formas, que constituem diferentes formas de linguagens.

De uma forma especial, o estudo do fenômeno de promoção de significado é importante para uma melhor compreensão das ações que ocorrem no ambiente de ensino, mediadas principalmente pelo uso da língua materna, mas também por um conjunto de simbologias próprias das diferentes áreas de conhecimento e por diferentes agentes presentes na situação de ensino. Pelo fato de a Química utilizar uma linguagem escrita e falada tão relacionada com o uso de simbologias exclusivas ou compartilhadas por outras áreas das ciências exatas, é importante a utilização de uma abordagem que considere explicitamente o papel da mediação dos signos lingüísticos na constituição do conhecimento humano, em especial nos processos de significação.

\subsection{3 - A tríade signo, objeto e interpretante}

A teoria semiótica de Peirce propõe que o conhecimento humano pode ser representado por uma tríade signo, objeto e interpretante. De acordo com o próprio Peirce, um signo é tudo aquilo que representa algo para alguém, como por exemplo, sinais escritos ou gestuais, desenhos, símbolos, situações ou imagens. Dentro da idéia da tríade, o signo é tudo aquilo que está relacionado com uma segunda coisa e que a representa. Esta segunda coisa que é representada pelo signo é chamada de objeto, a qual pode existir concretamente ou não. A palavra "béquer" pode ser citada como exemplo de signo que tem um objeto com existência concreta. Quando esta palavra (signo) 
é lida, a mente do leitor é levada a imaginar um artefato vítreo de forma aproximadamente cilíndrica aberto na parte de cima e fechado na parte de baixo. Na teoria semiótica, este artefato é denominado de objeto. Por outro lado, a palavra "saudade" pode ser citada como exemplo de signo que tem um objeto com existência abstrata, pois ela leva a mente do leitor a um sentimento relacionado à ausência de alguém ou algo.

A mediação é a principal característica dos signos, pois eles se colocam entre o sujeito e o mundo tanto para organizar atividades de produção material e simbólica, quanto para estruturar o pensamento. Ainda de acordo com Peirce, o signo dirige-se a alguém, isto é, cria na mente dessa pessoa um signo equivalente ou mais desenvolvido, denominado interpretante, que está relacionado aos construtos teóricos existentes nas mentes de quem pratica as mais variadas formas de conhecimento. Nos exemplos citados acima, as palavras "béquer" e "saudade" criam na mente do leitor as idéias respectivas relacionadas a estas palavras. Desta maneira, o signo, o seu objeto, e o interpretante criado na mente das pessoas formam uma tríade, a partir da qual podem ser mais bem compreendidos os processos de significação.

Ainda de acordo com Peirce, cada signo cria um interpretante que, por sua vez, é representamen ${ }^{1}$ de um novo signo, de forma que a semiose resulta numa série de interpretantes sucessivos, ad infinitum. Não haveria nenhum primeiro nem um último signo neste processo de semiose ilimitada [PEIRCE, 2005]. Nem por isso, entretanto, a idéia de semiose infinita implica num circulo vicioso ou auto-referente. Ao contrário, este processo sucessivo estaria se referindo a idéia de dialogia no pensamento - diálogo este entre as várias fases do ego - de maneira que, sendo dialógico, o pensamento se comporia essencialmente de signos. Como cada pensamento tem de dirigir-se a um outro, o processo contínuo de semiose (ou pensamento) só poderia ser interrompido, mas nunca realmente finalizado. Na vida cotidiana, devido às exigências práticas das realizações pessoais ou sociais, as séries de idéias não continuariam, de fato ad infinitum, mas tecnicamente a seqüência da semiose seria sempre possível [NÖTH, 2005, pp 72].

1 Para Peirce, o `representamen`é o signo em sua relação triádica com o objeto e o interpretante. 
Do ponto de vista de sua relação com os próprios elementos da tríade peirceana, os signos podem ser classificados em três possíveis grupos: signo em si mesmo, ou primeiridade; sua relação com seus objetos, ou secuntidade; sua relação com seus interpretantes, ou terceiridade [NÖTH, 2005]. Neste trabalho escolhemos relacionar as dimensões do conhecimento químico com as possíveis relações dos signos com seus objetos. Isto porque o estudo do signo em si mesmo é de base ontológica e sua contribuição se dá no âmbito do conhecimento da natureza do signo, o que não traz contribuições diretas ao estudo sobre o desenvolvimento de ambientes de ensino de química nos quais estamos interessados.

Já o estudo do signo em relação ao seu objeto descreve de que forma o signo promove seu significado [PEIRCE, 2005]. Como veremos adiante, na sua especificidade, o conhecimento químico dispõe de formas gráficas e fonéticas peculiares que são usadas quando lidamos com a interpretação de fenômenos da transformação dos materiais. O modo como estas representações promovem seus significados e a compreensão das ações que têm lugar durante o desenvolvimento das atividades de ensino são questões importantes no ensino da química, em especial quando a natureza destas representações é circunscrita às suas funções de mediação e de constituição do conhecimento.

Além disso, o campo coletivo na situação de ensino e aprendizagem, ou seja, a parte que pertencente tanto ao professor quanto ao estudante também está no âmbito das relações entre os signos e seus objetos, pois os interpretantes estão nas mentes de cada participante da situação de sala de aula, de forma que a relação entre o signo e o interpretante pertence apenas aos indivíduos particularmente. Com isso o campo de ação do professor na situação de ensino, que pode ser visto como um processo de significação numa relação dos signos com seus objetos, deve ser entendido como um campo comum a dois lados, de onde se podem extrair importantes relações nos processos de ensino e da aprendizagem.

Faz-se necessário observar que a abordagem do processo de significação que expomos não leva em consideração fatores de natureza sociológica ou culturais, como, por exemplo, o valo atribuído pela coletividade ás relações de nexo entre o signo e o objeto, ou ainda o propósito destas 
relações para fins de organizar ações no coletivo, entre outros fatores [GIORDAN, 2006].

Considerando as relações do signo com seu objeto, existem três tipos de signo: ícone, índice e símbolo [PEIRCE, 2005, pp. 10, 28, 47]. Os signos que têm o poder de significação por ostentar alguma semelhança com o seu objeto, semelhança esta visual ou de propriedades, são chamados de ícones. Como exemplo de ícone dentro do conhecimento químico, podemos sugerir a utilização de um 'objeto molecular' concreto do tipo bola-vareta de uma espécie química qualquer, como por exemplo, a água, no contexto de uma aula sobre a descontinuidade da matéria. No mesmo instante em que o professor utilizar este tipo de recurso em sua aula, a atenção do estudante será dirigida para as esferas distintas, talvez com colorações diferentes, e ligadas entre si. Este tipo de representação tem a intenção explícita de enfatizar duas propriedades: a descontinuidade da matéria nas unidades discretas da molécula, bem como a tridimensionalidade do ente molecular. Desta forma, por semelhança com as teorias de Dalton sobre a descontinuidade da matéria, e de Lewis sobre os pares eletrônicos, as bolas simbolizam os átomos de hidrogênio e oxigênio e as varetas as ligações químicas. Em nosso exemplo de ícone, qualquer pessoa sem o mínimo conhecimento químico (interpretante) e portanto, sem nunca ter tido contato com a idéia de molécula (objeto) poderá identificar no ícone 'objeto molecular' unidades discretas distintas separadas por algo que as une. Temos, portanto, a função de promover significação por semelhança de propriedades entre o ícone (objeto molecular) e seu objeto (ente molecular).

Os signos que promovem significação em virtude de uma ligação física direta com o objeto, indicando sua existência, são chamados de índices. Como exemplo de índice dentro do conhecimento químico, podemos citar a utilização do símbolo do elemento químico carbono (C) no contexto de uma aula sobre elementos químicos. Tão logo o professor utilize esta simbologia, a atenção do estudante será dirigida para o elemento químico carbono, que nesta situação, geralmente tem apenas o nome como principal propriedade. Os índices promovem significação pelo fato de indicarem o objeto e de serem automaticamente afetados por ele, de forma que a indefinição do objeto acarreta a perda do significado pretendido. No caso da aula de elementos 
químicos, se o professor não explicar com antecedência que a letra 'C' representa o elemento químico carbono (objeto), a escrita da mesma não será de nenhuma utilidade para a significação pretendida. Os índices não dependem do interpretante, uma vez que apenas apontam para outro signo, obtendo assim seu significado. No caso da nossa aula de elementos químicos, se estivesse presente um estudante que não conhecesse o idioma local, ele poderia mesmo assim compreender plenamente que a letra ' $C$ ' maiúscula estaria indicando um objeto utilizado na aula (carbono).

Finalmente, os signos que são associados aos seus objetos em virtude de uma lei ou convenção são chamados de símbolos. Todas as palavras são símbolos porque não denotam coisas em particular, mas espécies de coisas, próprios a sua língua de origem. Como exemplo de símbolo, podemos citar a palavra 'fósforo' numa aula sobre elementos químicos. Antes mesmo de o professor explicar a existência de um elemento químico com este nome, ao se pronunciar esta palavra vem à mente do estudante a idéia cotidiana do fósforo de acender fogo. Não é necessário que se apresente algum objeto que mostre o significado desta palavra na língua portuguesa, pois o mesmo já existe na mente do estudante. A palavra sozinha não denota um palito de fósforos em particular ou o elemento químico fósforo, mas um tipo ou algumas possibilidades de tipo de objeto de conhecimento. Os símbolos dependem do interpretante porque é nele que reside a lei de associação ao objeto. Não dependem de si mesmos, como no caso dos ícones, para promover o significado porque não têm qualquer semelhança com o objeto. $E$ não dependem de estar indicando fisicamente o objeto no instante em que são proferidas (como no caso dos índices), porque já existe uma associação da palavra com a idéia em questão.

Fora de seus contextos, toda forma de referência verbal na sala de aula, tomando cada palavra separadamente, é simbólica. Isto porque são utilizadas palavras como meio de referência aos objetos de conhecimento, a menos que o professor tenha diante de si o laboratório químico ou o quadro negro, pois desta forma poderá apontar para objetos ou utilizar diferentes formas de grafia para promover significação de qualidade indicial. Idealmente, se considerarmos apenas o âmbito de significados da língua portuguesa, toda forma de referência 
falada, fora de seus contextos, é simbólica, uma vez que os estudantes certamente compreenderão isoladamente quase todas as palavras que forem faladas. Dentro dos significados do contexto da sala de aula de química, no entanto, estas formas de referência podem ser simbólicas, indiciais ou icônicas, conforme descrito acima.

Ainda de acordo com Peirce, é difícil, senão impossível, encontrar algum signo desprovido da qualidade indicial. Semelhantemente, dentro do conhecimento químico, os mesmos signos poderão assumir qualidade indiciais, icônicas e simbólicas, dependendo do contexto em que são aplicados. O desejo dos educadores é que o ensino promova a migração das relações de qualidades indicial e icônica dos signos próprios do conhecimento químico, para uma relação de qualidade simbólica, ou seja, que os signos alcancem seus significados por se relacionarem com construtos teóricos presentes nas mentes dos estudantes.

\subsection{4 - As dimensões do conhecimento químico e os signos}

Uma dificuldade freqüente dos estudantes nas aulas de química é a de não entenderem o que o professor está dizendo. Quando profissionais da química se comunicam entre si, quase sempre não há necessidade de se explicitar se as referências são feitas ao nível macroscópico, submicroscópico ou simbólico, pois os mesmos operam apropriadamente entre todos os níveis. As referências a cada uma das dimensões do conhecimento são plenamente compreendidas pelos interlocutores, uma vez que conseguem transitar amplamente por todas elas. Já os estudantes geralmente sentem dificuldade de entender a qual dimensão do conhecimento os profissionais se referem quando é necessário transitar entre as mesmas.

Considerando individualmente a dimensão simbólica, macroscópica e submicroscópica do conhecimento químico, quais são os tipos de relação semiótica que prevalecem entre os signos e seus objetos? Passamos a analisar, sob a visão dos tipos de relação de qualidade dos signos, as formas de referência a cada uma das três dimensões do conhecimento químico.

A dimensão macroscópica do conhecimento químico, conforme descrito acima, trata dos fenômenos e processos que são perceptíveis e observáveis 
por meio de informações sensoriais e medições, como variação térmica, cores e cheiros em um laboratório. Os professores se referem a este nível de conhecimento, com muita freqüência, de forma oral após uma aula de laboratório. Neste caso são as palavras que constituem os signos a serem compartilhados pelo professor. Quando o professor fala sobre determinadas cores visualizadas, ele está se referindo a eventos específicos já conhecidos. Este tipo de informação é facilmente apreendido pelos estudantes, de forma que nas séries iniciais onde ocorre o contato com a química, aquilo que primeiro chama a atenção e provoca curiosidade são as informações trazidas do laboratório. Os estudantes não sentem dificuldade com as referências indiciais que os professores fazem na sala de aula: fica bastante claro a que o professor está se referindo quando, por exemplo, evoca a coloração de uma solução básica em presença de fenolftaleína. Existe caráter simbólico na representação macroscópica já que na situação de sala de aula podem ser feitos experimentos de pensamento utilizando conhecimentos trazidos do cotidiano. Podemos citar como exemplo uma situação em que o professor pede para os estudantes imaginarem o que acontece com cubos de gelo que são colocados dentro de um recipiente e deixados em temperatura ambiente. As palavras do professor vão direcionar o pensamento dos estudantes não para uma situação especifica vivida por eles, mas para conhecimentos gerais relacionados ao gelo e a temperatura ambiente, ou seja, para o interpretante. Neste caso, não existe caráter icônico porque, via de regra, não existe semelhança entre a representação macroscópica e o objeto de conhecimento.

Desta forma, quando os professores se referem à dimensão macroscópica do conhecimento, na maior parte das vezes as palavras promovem seus significados por indicar a existência de algo, e em alguns casos elas o fazem a partir dos construtos existentes na mente dos estudantes. Apesar de existirem estas duas componentes semióticas na dimensão macroscópica - indicial e simbólica - e de os professores por vezes se referirem a ambas numa mesma fala, não existe a menor possibilidade de confusão por parte dos alunos porque a referência indicial indica o mundo concreto, real. $O$ virtual, ou construto teórico, que é a referência simbólica, obtém significado do concreto, que é a forma de referência indicial. A vontade dos educadores é que 
durante as atividades de ensino nesta dimensão do conhecimento os estudantes dependam cada vez menos de referências indiciais e que as mesmas sejam transformadas em construtos teóricos capazes de serem acessados através de referência simbólica, ou do interpretante.

A dimensão submicroscópica do conhecimento químico trata do nível molecular dos fenômenos químicos, como o movimento e a interação das partículas. Este nível de conhecimento é um construto teórico resultado da moderna unificação do conhecimento químico teórico e experimental [HOFFMAN e LASZLO, 1991]. Nesta dimensão do conhecimento, os signos resultam de uma composição de palavras, figuras, analogias e metáforas. Em aulas de química os professores se referem a este nível de conhecimento geralmente durante explicações sobre transformações ou propriedades químicas. Quando o professor fala sobre colisões entre moléculas numa aula sobre cinética de partículas, é comum a apresentação de figuras onde existam partículas de formas variadas colidindo umas contra as outras. O professor não se refere a uma experiência vivida diretamente pelo estudante, que seria a visualização das partículas, mas utiliza analogias e metáforas para se aproximar do conhecimento pretendido. Este é o tipo de referência semiótica icônica, uma vez que o professor confia na relação de semelhança existente entre o objeto de conhecimento, que seria o estudo das propriedades cinéticas de moléculas, e o signo apresentado aos estudantes.

Este tipo de referência pode apresentar problemas, pois em toda analogia ou metáfora existem significados que se deseja que os estudantes se aproximem, como a noção de descontinuidade da matéria, e existem outros significados que se deseja que os estudantes se afastem, como a coloração dos entes moleculares. Caso não seja tratado adequadamente, pode se tornar em uma fonte de conceitos alternativos quando a semelhança de propriedades entre o ícone e o objeto não é tomada como motor da significação, e quando não se discute explicitamente quais são os significados corretos e os incorretos.

Esta propriedade da referência icônica nos coloca, ao mesmo tempo, uma limitação e um potencial para lidarmos com o conhecimento científico, uma vez que figuras, gráficos e esquemas se tornam universais justamente em 
função de sua múltipla capacidade de referência. Se a multiplicidade de referência abre um foco de disputa na negociação de significados, ela também nos faz lançar mão de outras formas de representação, com qualidades indicial e simbólica, para exatamente selecionar uma propriedade em particular, colocando em movimento os três motores da significação. Ou seja, nas situações de ensino, a relação de semelhança entre o ícone e o objeto é fonte de disputa entre o conjunto de critérios adotados pelo professor, que é apoiado no conhecimento oficial, e o conjunto de critérios adotados pelos estudantes. Esta mesma multiplicidade potencializa a criatividade do estudante para estabelecer vínculos entre três formas de representação de modo a construir interpretações sobre o fenômeno que se aproximem do conhecimento oficial. Se o ícone é fonte para elaboração de significados diversificados, é justamente esta característica que faz dele um signo particularmente útil para o ensino.

Existe caráter simbólico quando se trabalha com a dimensão submicroscópica, já que na situação de sala de aula observa-se um esforço por parte dos professores para fazer referência a construtos formados nas mentes dos estudantes. Podemos citar como exemplo de representação com qualidade simbólica quando o professor, em uma aula sobre os estados físicos da matéria, procura exemplificar a proximidade relativa dos átomos no estado de agregação sólido da matéria. O professor pode evocar oralmente como exemplo um recipiente contendo pequenas esferas (experimento de pensamento), de forma a exemplificar a pouca movimentação relativa entre os átomos comparada aos outros estados de agregação da matéria.

O caráter indicial em representações da dimensão submicroscópica do conhecimento químico deve ser explorado com cautela na sala de aula. Isto porque as representações desta dimensão do conhecimento químico não apontam (pelo menos não deveriam apontar) diretamente para nenhum objeto conhecido no mundo real dos estudantes ou de qualquer ser humano. Ao contrário, o objeto teórico do mundo no nível molecular deverá ser construído ao longo do curso de química, a partir de propriedades e conceitos que vão sendo aos poucos adicionados aos já existentes. Desta forma existe um perigo conceitual caso a utilização de objetos moleculares concretos ou virtuais aponte diretamente para objetos concretos do mundo sensível à percepção 
humana. Pelo contrário, no uso de tais objetos deve ser enfatizado o caráter icônico de semelhança e analogia com as propriedades de moléculas e átomos, e não um caráter indicial, para que os estudantes não pensem que os átomos têm cores ou que as ligações químicas são bastões. Caso exista caráter indicial ao se utilizar os signos desta dimensão isto se constituirá num problema em que incorrerão erros conceituais profundos, já que sempre que for feita referência a ela a atenção do estudante será levada para as figuras e formas concretas, e não para as funções que elas desempenham na construção de interpretações do fenômeno.

Desta forma, quando os professores se referem verbalmente à dimensão submicroscópica do conhecimento, em alguns casos as palavras promovem seus significados devido à semelhança existente entre as figuras presentes nas metáforas e o modelo de partículas atualmente aceito, e em outros casos elas o fazem com base nos construtos mentais dos estudantes. Neste caso existe possibilidade de confusão entre estas duas referências porque os estudantes podem não saber se o professor está se referindo às semelhanças icônicas ou ao construto teórico simbólico que se espera existir em sua mente, ou mesmo se a referência feita tem qualidade indicial. Os professores, neste caso, fazem referência a duas componentes virtuais em uma mesma dimensão do conhecimento. Também neste caso a vontade dos professores é que durante as atividades de ensino nesta dimensão do conhecimento os estudantes dependam cada vez menos de referências icônicas e que as mesmas sejam transformadas em construtos teóricos capazes de serem acessados por meio da referência simbólica do interpretante.

A dimensão simbólica do conhecimento químico trata das representações qualitativas, utilizando notações, terminologias e simbolismos especializados, e também trata das representações quantitativas, quando são utilizados gráficos e equações matemáticas. Este nível de conhecimento é fruto da experiência acumulada dos químicos por meio de práticas experimentais e teóricas, e também de congressos mundiais onde são convencionadas as melhores formas de notação. O signo a ser compartilhado pelo professor é composto de palavras, notações e equações, como no caso de uma aula em que há resolução de exercícios de cálculo de concentração de soluções. Estes 
signos compostos, por sua vez, significam grandezas, leis e construtos teóricos, frequentemente compartilhados pelos significados em torno de conceitos matemáticos. Em aulas de química os professores se referem a esta dimensão do conhecimento durante a execução de procedimentos teóricos utilizando equações, grandezas e leis, por exemplo, quando resolvem problemas teóricos junto com os estudantes.

Quando o professor resolve um exercício de cálculo de concentração de solução de forma dialogada em sala de aula, são comuns as referências às grandezas e às leis na forma de notações especializadas e equações antes, durante e depois da resolução. Vamos tomar como exemplo a resolução de um exercício onde a concentração de uma substância dependa da temperatura da solução e que seja necessário converter o valor de concentração em massa para concentração molar. Para resolver o exercício o professor lança mão dos três tipos de referência semiótica. A referência de qualidade icônica se faz presente quando gráficos são utilizados para se chegar a uma conclusão, seja através de semelhança geométrica ou algébrica. O signo, na forma de gráfico, por exemplo, promove significação pelo simples fato de existir semelhança visual ou de propriedades entre ambos. Em gráficos cartesianos, a semelhança com o objeto, no caso uma grandeza como a temperatura, ocorre na medida em o aumento ou diminuição da grandeza acompanha o aumento ou diminuição do valor da abscissa ou ordenada. Quando a atenção dos estudantes é direcionada para tal semelhança na dimensão macroscópica do conhecimento químico a promoção do significado ocorre através de qualidade semiótica icônica.

A referência indicial também está presente neste exemplo de resolução de exercícios, quando se representam grandezas por meio de letras ou símbolos especiais. Quando o professor estabelece em uma aula que a letra 'M' maiúscula se refere à concentração molar, ao terminar de efetuar o cálculo da concentração junto com os estudantes e escrever o valor final da concentração na forma ' $M=2,0 \mathrm{~mol} / \mathrm{L}$ ', o pensamento do estudante será levado de volta ao significado inicial da letra 'M', no caso concentração molar. Apesar de durante a resolução algébrica do exercício o pensamento dos estudantes provavelmente estar voltado para o algoritmo de resolução, em um 
determinado momento, geralmente ao final da resolução, seu pensamento será levado ao significado do cálculo dentro do contexto da química. Estas letras ou símbolos recebem seus significados porque estão simplesmente indicando a existência das grandezas, o que configura a significação de qualidade indicial.

E a referência de qualidade simbólica está presente quando se lança mão de conceitos e idéias já dominados pelos estudantes para a resolução do problema. Em nosso problema de resolução de exercícios de concentração, podemos citar como exemplo a exemplificação do processo de solubilização de determinado sólido solúvel em água, por exemplo, cloreto de sódio. Tão logo o professor inicie a descrição da adição de um sólido branco em água a mente dos estudantes será facilmente levada a imaginar uma cena parecida, não se referindo a uma situação específica, mas a significados já dominados pelos estudantes, como água, sal de cozinha, recipiente vítreo, objeto para agitar a solução e outros. Neste caso o conceito de que sal de cozinha se dissolve em água é plenamente conhecido por estudantes do ensino básico, e pode ser acessado pelos professores por meio de referências exclusivamente verbais, para dar significação de qualidade simbólica no contexto da aula de química. Assim, a exemplificação do processo de solubilização de um sal promove seu significado a partir de relações com outras palavras e conceitos conhecidos dos estudantes (caráter simbólico), e não por alguma semelhança presente no próprio signo (caráter icônico) ou por estar este exemplificando um caso específico do objeto de conhecimento (caráter indicial).

Desta forma, quando os professores se referem à dimensão simbólica do conhecimento, algumas vezes as palavras promovem seus significados por indicar a existência de algo, outras vezes devido à semelhança existente entre as figuras presentes nas metáforas e os modelos atualmente aceitos, e em outros casos as palavras promovem seus significados pela relação com construtos teóricos. Neste caso a possibilidade de confusão entre os três tipos de qualidade semiótica é grande, e os estudantes certamente ficarão confusos por não saberem qual tipo de qualidade (icônica, indicial ou simbólica) é o mais apropriado para que as palavras e representações diversas tenham significado. O caminho mais curto encontrado pelos estudantes para a resolução de problemas é tratar esta dimensão do conhecimento químico de uma forma 
familiar a eles: a matemática. Os professores, neste caso, fazem referência aos significados com o uso das três qualidades semióticas em uma mesma dimensão do conhecimento. Também neste caso a vontade dos professores é que durante as atividades de ensino nesta dimensão do conhecimento os estudantes dependam cada vez menos de referências icônicas, indiciais e simbólicas simples, e que as mesmas sejam transformadas em construtos teóricos capazes de serem acessados através de referências simbólicas complexas.

\subsection{5 - Os signos e as representações químicas computacionais: o ensino de química}

Tendo indicado os principais elementos de ligação entre a teoria semiótica de Peirce e as situações de ensino de Química, vamos nos concentrar agora na confluência deste ensino com as interfaces computacionais. O desenvolvimento do computador tem influenciado fortemente seu uso na escola, de forma que a miniaturização pode ser considerada como um dos fatores que possibilitaram a popularização dessa tecnologia ao permitir o acesso dos usuários domésticos ao processamento e armazenamento massivo de informação no computador de mesa. Além disso, os efeitos produzidos pelas interfaces gráficas vêm sendo aprimorados desde a criação de ambiente de janelas. Com isso a comunicação entre usuário e computador é feita por meio de ícones, e a execução dos aplicativos não exige conhecimento de programação por parte do aluno [GIORDAN, 2005].

Quando as representações são mediadas pelos recursos gráficos oferecidos atualmente pelo computador, a relação entre os signos e seus objetos, em algumas dimensões da realidade química, pode ser profundamente modificada. Os recursos de animação de imagens e simulação oferecidos pelo uso dos computadores podem trazer um novo caminho de construção do conhecimento na sala de aula de química.

No nível macroscópico, os signos geralmente se fazem presentes na sala de aula de química ou laboratório didático pelo emprego das palavras como forma de referência aos fenômenos, ou da percepção dos mesmos 
através dos sentidos, como a visualização, cheiro ou variação de temperatura, por exemplo.

Quando se utiliza o computador, no entanto, o caráter icônico das representações nesta dimensão do conhecimento químico passa a ter potencial de uso benéfico ao ensino. O próprio fenômeno a ser estudado pode ser representado em uma animação sem a necessidade de os estudantes vivenciarem o mesmo em laboratório. Em alguns casos isso é necessário devido à periculosidade do fenômeno, como no caso das transformações químicas que ocorrem em vulcões em erupção. Com isso o caráter icônico estará presente de forma a tornar mais claro um experimento de pensamento, que não foi vivenciado pelo estudante. Quando o experimento de pensamento é apenas narrado, como por exemplo as mudanças de fase da água, o mesmo pode ser imaginado em alguns casos, uma vez que o estudante conhece pelo menos a maior parte dos componentes do mesmo, como cubos de gelo, água na forma liquida e vapor d'água. Em outros casos o experimento pode não ser tão facilmente imaginável, como no caso de fenômenos de transmutação nuclear que ocorrem em reatores atômicos. Ao se utilizar uma animação, a imaginação é auxiliada pela visualização gráfica. Além disso, o foco de visualização do estudante pode ser direcionado corretamente para as propriedades e suas representações correspondentes, como por exemplo a estabilização da temperatura durante mudanças de fase e a forma gráfica da representação equivalente. A utilização de recursos computacionais para visualização de representações desta dimensão do conhecimento químico possibilita a visualização de características importantes, do ponto de vista do conhecimento químico, de fenômenos de difícil visualização direta.

No nível submicroscópico, os signos se fazem presentes nas representações imagéticas, além do uso das palavras como forma de referência aos construtos teóricos próprios desta dimensão do conhecimento químico. O caráter icônico destas representações está presente na sala de aula de química geralmente na forma de figuras estáticas que simbolizam os átomos e suas várias formas de representação e agrupamento no caso de livros didáticos e modelos atômicos concretos. Mesmo quando o computador é utilizado como meio de representação, é freqüente a utilização de imagens em 
que a natureza particulada da matéria é apresentada em um formato onde muitas características próprias deste nível de representação são passadas por alto.

A utilização do computador pode ser feita de forma que a aparência sugerida da qualidade icônica das representações nesta dimensão do conhecimento químico traga mais benefícios ao ensino da química. Os recursos gráficos computacionais, amplamente disponíveis na atualidade, aliados a utilização de softwares de código aberto, junto com o conhecimento sobre simulações por mecânica e dinâmica molecular, podem apresentar com clareza muitas peculiaridades e propriedades inerentes aos processos relativos a interações dinâmicas no nível de partículas atômicas, como por exemplo a movimentação relativa entre as partículas devido a colisões intermoleculares e a própria temperatura. Desta forma o caráter icônico deste tipo de representações pode ser utilizado para construir conhecimento que, ou não seria possível de outra forma, ou seria muito mais difícil utilizando apenas palavras e imagens estáticas. A utilização de recursos computacionais para visualização de representações desta outra dimensão do conhecimento químico pode trazer para os estudantes uma perspectiva mais alinhada com o conhecimento científico atualmente aceito.

Além das contribuições em cada dimensão do conhecimento químico, o computador traz ainda a possibilidade de integração de representações dos níveis macroscópico, submicroscópico e simbólico, ou de composições de duas destas dimensões do conhecimento, com o objetivo de propiciar a elaboração de significados por meio de representações, principalmente do nível simbólico do conhecimento químico. Neste sentido, muitos ambientes virtuais de ensino de química têm sido desenvolvidos na última década, conforme descrito no Capítulo 1 deste trabalho, com o objetivo de permitir o estudante visualizar de forma integrada as várias representações do conhecimento químico.

\subsection{6 - Síntese}

Conforme dito no início, tínhamos como objetivo neste texto trazer uma compreensão mais aprofundada a respeito dos processos de significação de representações químicas na sala de aula a partir da contribuição da teoria 
semiótica de Peirce. Conforme descrito acima, em cada dimensão do conhecimento químico prevalecem determinadas qualidades semióticas de significação. No nível macroscópico do conhecimento químico prevalecem as relações indiciais e simbólicas. No nível submicroscópico são encontradas predominantemente as relações icônicas e simbólicas de significação. No nível simbólico do conhecimento químico, no entanto, são encontradas todas as qualidades de significação semiótica, ou seja, indiciais, icônicas e simbólicas. Com isso a dimensão simbólica do conhecimento químico certamente oferece maior dificuldade de compreensão dentro do que atualmente é proposto como conhecimento químico oficialmente aceito.

Também tínhamos como objetivo discutir a contribuição das representações computacionais nos processos de significação na sala de aula de química. Conforme visto acima, as possibilidades de representação das dimensões do conhecimento químico atualmente veiculadas por intermédio dos computadores permitem visualizar fenômenos de difícil acesso, ou mesmo de fenômenos que não poderiam ser visualizados de outra maneira. Além disso, com o uso do computador, é possível visualizar de forma dinâmica e integrada as representações pertinentes a cada dimensão do conhecimento químico, o que possibilita uma compreensão holística das representações e dos conceitos associados.

No desenvolvimento do programa Construtor procuramos associar duas formas distintas de signos próprios da química. Um deles, conhecido como fórmula estrutural condensada, está relacionado com a dimensão simbólica do conhecimento químico. O outro, o qual é construído sob demanda através do programa Construtor, é um objeto molecular virtual tridimensional, o qual está relacionado com a dimensão submicroscópica do conhecimento químico.

A partir do uso do programa computacional Construtor, descrito neste trabalho, estudantes de Ensino Médio podem criar estruturas tridimensionais virtuais a partir de fórmulas estruturais condensadas, como $\mathrm{CH}_{3} \mathrm{CH}_{2} \mathrm{CH}_{2} \mathrm{CH}_{3}$ (Tabela 5). Com esta ferramenta os estudantes podem visualizar as características da dimensão submicroscópica da matéria, que é o objeto molecular virtual resultante, a partir de uma representação da dimensão simbólica, que é a própria fórmula estrutural condensada. 
Ou seja, a partir de uma representação com qualidade fortemente simbólica, ou convencional (fórmula estrutural condensada), o estudante tem a possibilidade de elaborar significado mais apropriado, dentro do atual paradigma da natureza particulada da matéria, com o auxílio da mediação de uma representação com qualidade icônica, de significação através de semelhança, no caso o objeto molecular virtual (Tabela 5).

\begin{tabular}{|c|c|c|c|}
\hline Representação & $\begin{array}{c}\text { Tipo de } \\
\text { Representação } \\
\text { Química }\end{array}$ & $\begin{array}{c}\text { Dimensão do } \\
\text { Conhecimento } \\
\text { Químico }\end{array}$ & $\begin{array}{c}\text { Qualidade } \\
\text { Semiótica }\end{array}$ \\
\hline $\mathrm{CH}_{3} \mathrm{CH}_{2} \mathrm{CH}_{2} \mathrm{CH}_{3}$ & $\begin{array}{c}\text { Fórmula } \\
\text { Estrutural } \\
\text { Condensada }\end{array}$ & Simbólica & Simbólica \\
\hline & $\begin{array}{c}\text { Objeto Molecular } \\
\text { Virtual } \\
\text { Tridimensional }\end{array}$ & Submicroscópica & Icônica \\
\hline
\end{tabular}

Tabela 5. A tabela relaciona, através do exemplo de duas diferentes representações de uma molécula de butano (primeira linha), o tipo da representação (segunda linha), a dimensão do conhecimento químico associado (terceira linha), e a qualidade semiótica da significação (quarta linha).

A vontade dos professores de química é que os mesmos sempre pudessem utilizar objetos moleculares, virtuais ou concretos, para suas aulas sobre estrutura e propriedades da matéria e suas transformações. No entanto, por motivos de praticidade, são utilizadas as representações simplificadas, com letras e números, como a fórmula estrutural condensada da Tabela 5. A despeito do uso de representações simplificadas por motivos de contingência, é necessário que os significados destas representações se tornem disponíveis aos estudantes. O uso do programa Construtor pode auxiliar o estudante na elaboração destes significados, já que o mesmo pode gerar objetos moleculares virtuais, de significação com qualidade icônica, a partir de representações com qualidade simbólica ou convencional. Ao utilizar o programa Construtor, o estudante pode elaborar significados com meios mediacionais mais sofisticados, os objetos moleculares, de forma que, quando o mesmo se deparar com representações da dimensão simbólica do conhecimento 
químico, estas possam ser facilmente relacionadas com o significado da dimensão submicroscópica. 


\section{1 - Construtor de objetos moleculares}

O programa computacional Construtor possui duas interfaces distintas. Em uma delas, chamada neste trabalho de interface de simulação, o estudante pode obter objetos moleculares virtuais tridimensionais a partir de uma fórmula molecular condensada. Na outra interface, chamada neste trabalho de interface de animação, o estudante tem a sua disposição uma interface gráfica onde o mesmo pode manipular pequenas esferas coloridas e bastões de forma a poder construir representações bidimensionais de moléculas. Passaremos a descrever a primeira interface do programa Construtor.

O programa computacional descrito a seguir foi desenvolvido para estudantes iniciantes em química do ensino médio ou superior. Através deste programa é possível construir e visualizar objetos moleculares virtuais e tridimensionais em computadores com monitor de vídeo, mouse e teclado. A construção do objeto molecular ocorre em um computador servidor, acessível pela internet através do protocolo de comunicação hipertexto. A interface gráfica com o usuário foi desenvolvida para o navegador Internet Explorer ${ }^{\circledR}$ e sistemas operacionais Windows ${ }^{\circledR}$. Este programa é utilizado de forma simplificada, onde o usuário submete a fórmula estrutural condensada de um composto orgânico através de um campo tipo formulário em uma página hipertexto acessada pela internet, e obtém como resultado o objeto molecular virtual e tridimensional na mesma página hipertexto.

A principal filosofia presente no desenvolvimento do programa computacional Construtor é abrir mão da utilização de um banco de dados para a disponibilização de estruturas moleculares para os usuários. Ao invés disso, a idéia principal do programa é montar o arquivo de estrutura molecular, otimizar geometricamente a estrutura e gerar informações para 200 quadros de movimentação molecular simulada, sob a demanda do usuário. O tempo necessário para que estas etapas sejam concluídas, na atual versão do programa construtor, é de apenas três segundos, para uma molécula com 20 átomos, em um computador servidor tipo PC com processador AMD $2.0 \mathrm{GHz}$ e 
256 MB de memória RAM. O tempo de resposta ao usuário, naturalmente, dependerá da velocidade de conexão com a internet.

O desenvolvimento do programa computacional Construtor envolve a utilização de um pacote de programas de modelagem molecular, utilizados na otimização da geometria molecular e na simulação por dinâmica molecular. Este tipo de programa computacional tem sido desenvolvido por vários grupos de pesquisa em muitos países, os quais são disponibilizados gratuitamente na internet na filosofia do software livre. A utilização deste tipo de programa geralmente se dá em ambientes de pesquisa e ensino no nível de pósgraduação, uma vez que exigem conhecimento aprofundado de teorias químicas, matemáticas e computacionais. Além disso, estes programas são geralmente utilizados em ambiente GNU/Linux, o que requer conhecimentos específicos sobre a utilização de programas computacionais a partir da linha de comando, o que acrescenta conhecimentos específicos e gera barreiras para a utilização de boa parte de usuários cursando o Ensino Médio ou Superior de áreas não específicas da computação. Dessa forma, é necessário o desenvolvimento de um programa computacional que ofereça interface gráfica simplificada para que possa ser utilizado por estudantes iniciantes em química.

O primeiro passo para o desenvolvimento do programa computacional descrito neste trabalho foi a seleção de um pacote de programas de modelagem molecular. Escolhemos utilizar o pacote de programas Tinker [PONDER e RICHARDS, 1987] em virtude de o mesmo estar disponibilizado como código aberto na internet e ser amplamente utilizado na comunidade de pesquisadores da área de modelagem molecular. Além disso, este pacote de programas oferece a possibilidade de uso dos programas sem suas interfaces gráficas, o que diminui a demanda por processamento no computador servidor. Os dois programas utilizados do pacote Tinker foram o MINIMIZE, com 627 KB de tamanho, utilizado na otimização de geometria através da minimização de energia potencial, e o programa OPTIMIZE, como 669 KB de tamanho, utilizado para as simulações por dinâmica molecular.

O segundo passo foi o desenvolvimento de um programa computacional que gerasse os arquivos de entrada para a utilização do pacote de programas Tinker, a partir da fórmula estrutural condensada de estruturas moleculares. $\mathrm{O}$ 
programa descrito neste trabalho foi escrito em linguagem $C$ padrão ANSI [KERNIGHAN e RITCHIE, 1988], e pressupõe um sistema operacional GNU/Linux para sua execução. O código fonte do programa tem apenas 800 linhas e, depois de compilado com o compilador gcc (versão 4.0.2), o programa executável tem $27 \mathrm{~KB}$ de tamanho. O desenvolvimento inicial do programa foi realizado em uma distribuição GNU/Linux RedHat 9.0, e o programa final foi executado com sucesso também nas distribuições GNU/Linux Fedora 2 a 4 . A principal tarefa do programa é gerar um arquivo de coordenadas tridimensionais de átomos (Figura 2), dentre outras informações relevantes, unicamente a partir de sua fórmula estrutural condensada (exemplos: $\mathrm{CH}_{3} \mathrm{CH}_{2} \mathrm{CH}_{3}, \mathrm{CH}_{3} \mathrm{CH}_{2} \mathrm{CHO}, \mathrm{CH}_{3} \mathrm{CH}_{2} \mathrm{COCH}_{3}$ ou $\mathrm{CH}_{3} \mathrm{OCH}_{2} \mathrm{CH}_{3}$ ).

\begin{tabular}{|lrrrrrrrl|}
\hline & 8 & & & & & & & \\
$\mathrm{C}$ & 0.780733 & 0.000000 & 0.262842 & 1 & 2 & 3 & 4 & 5 \\
$\mathrm{H}$ & 0.227031 & 0.901282 & -0.088869 & 5 & 1 & & \\
$\mathrm{H}$ & 0.227031 & -0.901282 & -0.088869 & 5 & 1 & & \\
$\mathrm{H}$ & 0.762957 & 0.000000 & 1.377422 & 5 & 1 & & & \\
$\mathrm{C}$ & 2.219267 & 0.000000 & -0.262842 & 1 & 1 & 6 & 7 & \\
$\mathrm{H}$ & 2.772969 & 0.901282 & 0.088869 & 5 & 5 & & \\
$\mathrm{H}$ & 2.772969 & -0.901282 & 0.088869 & 5 & 5 & & \\
$\mathrm{H}$ & 2.237043 & 0.000000 & -1.377422 & 5 & 5 & & \\
& & & & & & & \\
\end{tabular}

Figura 2. A figura representa um arquivo de coordenadas tridimensionais geometricamente otimizadas em formato $X Y Z$ de uma estrutura molecular de fórmula estrutural condensada $\mathrm{CH}_{3} \mathrm{CH}_{3}$.

A Figura 2 representa um arquivo em formato $X Y Z$, o qual é próprio de entrada de dados para o pacote de programas Tinker. Neste formato cada linha traz informações de posicionamento, carga parcial e matriz de conectividade (informação que revela a quais outros átomos o átomo em questão está quimicamente ligado) de um único átomo. A única exceção é a primeira linha do arquivo, a qual deve conter um número que revele a quantidade de átomos fornecida pelo arquivo. Em cada linha do arquivo a primeira coluna indica a representação do átomo em forma de símbolo atômico. A segunda, terceira e quarta colunas representam o posicionamento do átomo nas coordenadas cartesianas $X, Y$ e $Z$, respectivamente. A quinta coluna representa o tipo atômico, o qual informa ao programa a carga relativa do átomo, para efeitos de 
cálculo de energia potencial durante a otimização de geometria. Da sexta coluna em diante está a matriz de conectividade do átomo.

A estratégia de montagem do arquivo de coordenadas tridimensionais é a avaliação do tipo atômico, o qual indica se o oxigênio está em um éter $\left(\mathrm{CH}_{3} \mathrm{OCH}_{3}\right)$ ou em um álcool $\left(\mathrm{CH}_{3} \mathrm{CH}_{2} \mathrm{OH}\right)$, de cada símbolo atômico $(\mathrm{C}$ ou $\mathrm{H})$ ou grupo de símbolos atômicos $\left(\mathrm{CH}_{3} \mathrm{Ou} \mathrm{CH}_{2}\right)$, bem como de seus antecessores e predecessores. Desta forma, ao receber a string $\mathrm{CH}_{3} \mathrm{CH}_{2} \mathrm{CH}_{3}$, o programa automaticamente tenta encontrar agrupamentos conhecidos de átomos. Um loop é iniciado a cada string, correspondente a uma estrutura molecular. Dentro deste loop o programa tenta identificar cada agrupamento de átomos dentro das possibilidades fornecidas previamente no programa. Cada agrupamento identificado gera parte do arquivo de coordenadas tridimensionais e 0 programa é finalizado quando todas as partes da string são identificadas, de forma ordenada, e a string termina da forma esperada, dentro de uma lógica de ligações químicas em quantidade e distância apropriadas. Caso o programa não consiga montar o arquivo de coordenadas em 100 iterações, sendo cada iteração uma tentativa de identificação de agrupamento, contadas a partir da primeira tentativa, o programa também é finalizado sob a hipótese de que existe inconsistência na fórmula estrutural condensada fornecida. Uma outra hipótese aceita pelo programa é a de que o mesmo desconhece pelo menos uma parte da representação fornecida, uma vez que até o momento ele é capaz de reconhecer hidrocarbonetos, compostos halogenados, álcoois, aldeídos, cetonas e éteres. A presente versão do programa Construtor é capaz de construir moléculas de cadeia simples ou ramificadas, de cadeia principal aberta ou cíclica com até 30 átomos de carbono, e ramificações com até 4 átomos de carbono, bem como também moléculas com insaturações correspondentes a ligações duplas e triplas.

É importante ressaltar que as coordenadas tridimensionais presentes no arquivo gerado diretamente pelo programa Construtor não se encontram geometricamente otimizadas. A otimização da geometria será realizada de forma automatizada um pouco mais adiante. No momento em que o arquivo de coordenadas tridimensionais é gerado os átomos de carbono se encontram enfileirados no eixo X (Figura 3) e os hidrogênios se encontram enfileirados ao 
lado de seus respectivos carbonos, o que corresponde a uma situação geometricamente inconsistente com o conhecimento químico atual. Isto se deve a adoção de uma estratégia de construção do arquivo de coordenadas tridimensionais, onde os carbonos são todos colocados sobre o eixo $X$, os hidrogênios são colocados no eixo $\mathrm{Y}$, e as ramificações são colocadas no eixo Z. Apesar de estas informações iniciais de geometria serem incorretas 0 programa de otimização de geometria necessita de uma média de 20 iterações para trazer estas estruturas para geometrias próximas àquelas teoricamente esperadas, ou seja, os programas de otimização são capazes de corrigir a geometria inicial fornecida pelo programa Construtor. A quantidade de iterações necessárias para cada estrutura molecular varia com a quantidade de átomos e depende também da própria complexidade da estrutura, como presença de insaturações e ramificações.

\begin{tabular}{|lllllllll|}
\hline & 8 & & & & & & \\
$\mathrm{C}$ & 1.000000 & 0.000000 & 0.000000 & 1 & 2 & 3 & 4 & 5 \\
$\mathrm{H}$ & 1.000000 & 1.000000 & 0.000000 & 5 & 1 & & & \\
$\mathrm{H}$ & 1.000000 & 2.000000 & 0.000000 & 5 & 1 & & & \\
$\mathrm{H}$ & 1.000000 & 3.000000 & 0.000000 & 5 & 1 & & & \\
$\mathrm{C}$ & 2.000000 & 0.000000 & 0.000000 & 1 & 1 & 6 & 7 & \\
$\mathrm{H}$ & 2.000000 & 1.000000 & 0.000000 & 5 & 5 & & & \\
$\mathrm{H}$ & 2.000000 & 2.000000 & 0.000000 & 5 & 5 & & \\
$\mathrm{H}$ & 2.000000 & 3.000000 & 0.000000 & 5 & 5 & & \\
& & & & & & & & \\
\hline
\end{tabular}

Figura 3 A figura representa um arquivo de coordenadas tridimensionais sem otimização de geometria em formato $X Y Z$ de uma estrutura molecular de fórmula estrutural condensada $\mathrm{CH}_{3} \mathrm{CH}_{3}$.

O terceiro passo foi o desenvolvimento da interface gráfica com o usuário. Decidimos disponibilizar a utilização do programa através de uma página hipertexto na internet, ao invés de disponibilizar o mesmo para ser baixado e instalado. Esta decisão se baseia na atual tendência de convergência de utilização dos recursos disponibilizados na internet através de navegadores de páginas hipertexto. Atualmente grande parte dos recursos disponibilizados na internet é acessada através de navegadores hipertexto, desde correio eletrônico, passando por acesso a contas bancárias, até jogos eletrônicos disponibilizados em formatos diversos. A maior vantagem deste tipo 
de disponibilização está na facilidade de lançamento de versões atualizadas do programa, o que não requer que os usuários baixem e instalem novas versões, sendo necessário apenas a mudança no servidor. A Figura 4 representa a interface gráfica da atual versão do programa computacional Construtor, na qual acrescentamos opções de visualização do objeto molecular.

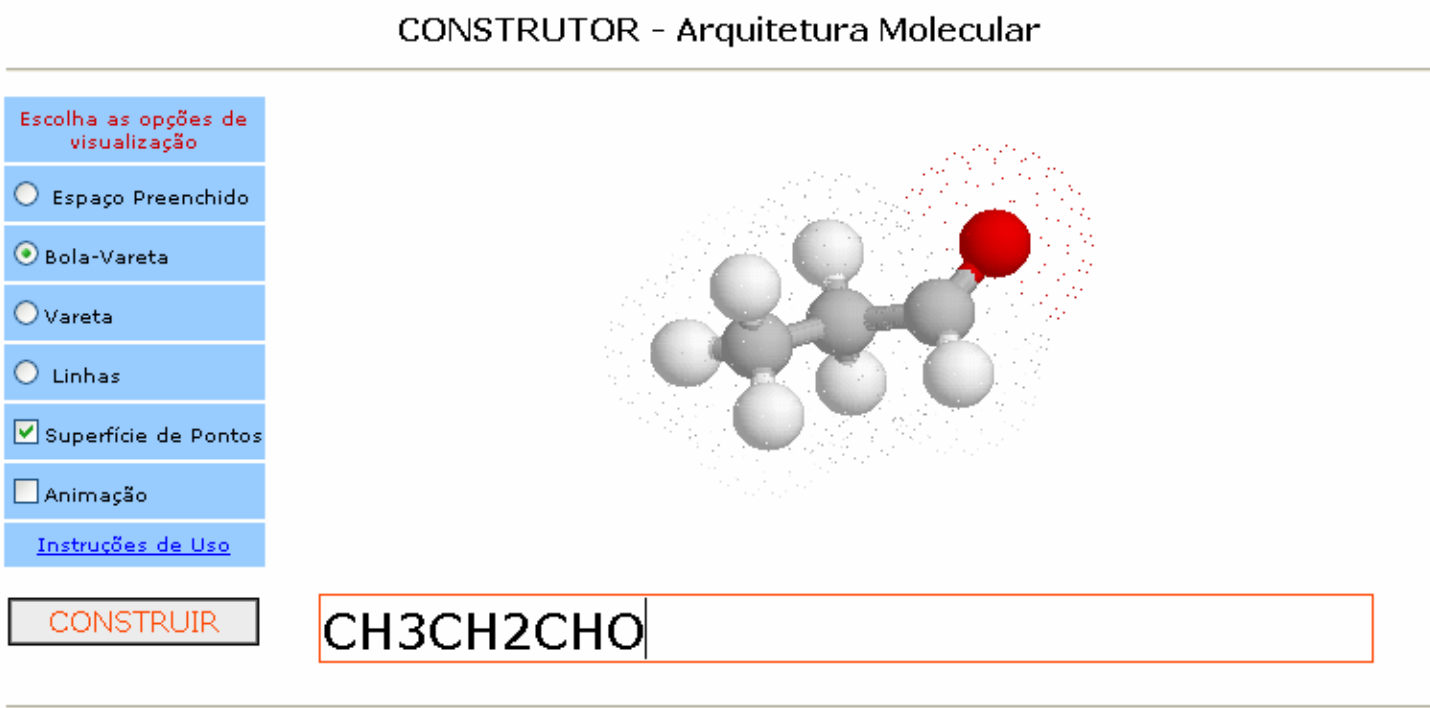

(9) LAPEQ - 2006

Figura 4. A figura representa a interface gráfica de simulação do programa Construtor. Esta interface contém um objeto molecular virtual tridimensional construído com o auxílio do programa Construtor.

Escolhemos utilizar um servidor Apache $^{1}$ para a disponibilização das páginas hipertexto na internet, escolha esta feita com base no simples fato de termos experiência em sua utilização. Desenvolvemos então um script em linguagem PHP, após a devida inserção de parâmetros do interpretador PHP no servidor apache, para que os usuários pudessem fazer uso do programa Construtor, presente no computador servidor, através de uma página hipertexto disponibilizada na internet. Na página hipertexto utilizada como interface gráfica (Figura 4), existe um campo onde o usuário escreve uma seqüência de letras e números correspondente a uma fórmula estrutural condensada. Ao lado deste campo existe um botão (construir) que, ao ser acionado, envia a seqüência de letras e números, a que chamaremos de string, para o computador servidor

1 http://www.apache.com. Acessado em 21/10/2007. 
através de seu navegador hipertexto, utilizando o método POST da linguagem HTML.

O script desenvolvido (Figura 5) tem a função de receber a string, retirar da mesma qualquer informação desnecessária, como espaços, acionar o programa Construtor utilizando a string como parâmetro principal, acionar os programas de otimização de geometria e simulação por dinâmica molecular do pacote Tinker, e devolver para o navegador do usuário o arquivo de coordenadas tridimensionais correspondente a string.

Após receber e processar a string, o script aciona o programa Construtor utilizando como parâmetro principal a própria string. Com isso o programa Construtor irá gerar um arquivo de coordenadas tridimensionais com geometria inicial (Figura 3) e com informações relevantes, como matriz de conectividade e tipos atômicos. Como a finalização do programa Construtor, o script acionará um programa de otimização de geometria do pacote Tinker. Este programa executará a otimização da geometria (Figura 2) tendo como critério a minimização de energia potencial da estrutura molecular, a partir das informações presentes no arquivo gerado pelo programa Construtor.

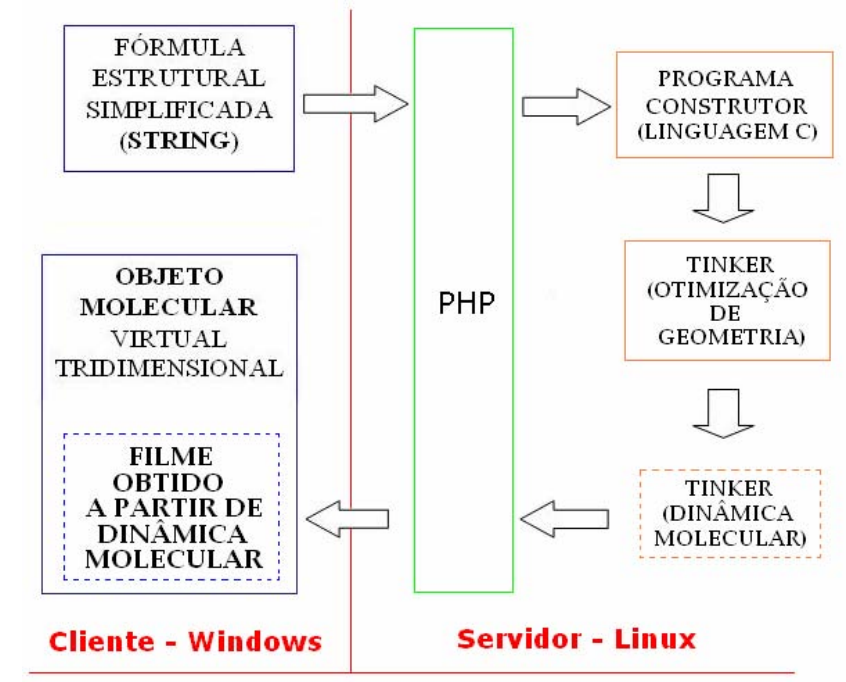

Figura 5. A figura representa o fluxograma das etapas de funcionamento do programa Construtor. O programa Construtor é executado em um servidor GNU/Linux a partir de navegadores hipertexto comuns.

Após a finalização da otimização de geometria, o script acionará um programa de simulação por dinâmica molecular, também do pacote Tinker, o 
qual irá gerar um arquivo com 200 quadros de movimentação molecular (simulação de 200 femtosegundos salvando 1 quadro a cada femtosegundo). Com a finalização da simulação por dinâmica molecular, o script finalmente devolverá ao usuário o último arquivo gerado, correspondente a string enviada inicialmente, contendo as informações de uma estrutura tridimensional de molécula e de sua movimentação simulada. O script foi desenvolvido de forma a automatizar completamente o processo, de forma que o usuário necessita apenas digitar uma seqüência de letras e números no campo apropriado (Figura 4), clicar o botão "construir", e aguardar em média 2 segundos para obter o arquivo correspondente ao objeto molecular virtual tridimensional.

O uso do programa Construtor, em sua atual versão, exige a utilização do plug-in MDL-Chime ${ }^{\circledR}$ para visualização automatizada do arquivo resultante. A instalação deste plug-in permite que os usuários visualizem o arquivo resultante em seus navegadores como um objeto molecular tridimensional. A necessidade de uso deste plug-in certamente coloca um obstáculo na utilização do programa Construtor, uma vez que exige instalação prévia e muitos locais de uso estudantil não permitem a instalação de quaisquer programas por usuários. Com isso estamos desenvolvendo uma nova versão da interface gráfica do programa Construtor, onde o usuário terá a opção de instalar o plugin MDL-Chime ${ }^{\circledR}$ ou de baixar automaticamente um visualizador molecular escrito em linguagem Java, chamado Jmol. Estamos acrescentando esta opção em virtude de as máquinas virtuais Java estarem se tornando cada vez mais populares entre os usuários de computadores pessoais.

A instalação do programa Construtor em sua atual versão exige a compilação, utilizando um compilador gcc, do Programa Construtor, de dois programas do pacote Tinker (otimização de geometria e simulação por dinâmica molecular) e a utilização da página hipertexto e do script PHP para acesso via internet.

Através deste programa estudantes de ensino médio podem visualizar de maneira simplificada a fórmula tridimensional de uma molécula a partir de sua fórmula estrutural condensada, sem a necessidade de conhecimentos sobre a utilização de programas de mecânica e dinâmica molecular, que apresentam dificuldades de uso até mesmo para estudantes do ensino superior 
e pós-graduação.

\subsection{1 - Interfaces com o usuário}

Animação

O ambiente gráfico de animação, que gera visualizações bidimensionais estáticas, foi escrito com o auxilio do aplicativo Flash $®$, que é um aplicativo de uso geral de construção de animações gráficas. Neste aplicativo, desenhos bidimensionais podem ser criados a partir de elementos simples de geometria. Os desenhos podem ser criados em uma quantidade variável de quadros com posicionamentos diferentes, de forma que a sobreposição dos quadros cria a sensação visual de movimentação do desenho. A possibilidade de criação de desenhos diferentes em camadas separadas, como parte de uma mesma animação, favorece um ambiente de edição organizado e planejado.

A interface de animação do programa Construtor é capaz de gerar animações estáticas bidimensionais. O programa não apresenta a opção de movimentação dos átomos e moléculas, por que o mesmo é utilizado pelos alunos em um estágio de conhecimento inicial, logo após a manipulação de objetos moleculares concretos e registro de estruturas moleculares em papel. $\mathrm{Na}$ Figura 6 apresentamos uma tela do aplicativo Construtor e também da interface de visualização produzida pelo plug-in Chime ${ }^{\circledR}$.

No ambiente de animação gráfica, os estudantes dispõem de uma barra de ferramentas na parte inferior da tela. Nesta barra de ferramentas estão disponibilizadas figuras geométricas bidimensionais que funcionam como objetos virtuais, manipuláveis pelo usuário em quantidade e posicionamento. A forma geométrica destes objetos mimetiza o formato dos objetos moleculares concretos do tipo bola-vareta, de forma que existem 'bolas' e 'varetas' virtuais em quantidade ilimitada, bem como um espaço bidimensional à disposição dos estudantes, onde os mesmos podem ser manipulados. Escolhemos oferecer aos estudantes uma área de trabalho bidimensional, bem como objetos moleculares bidimensionais, para não oferecer um obstáculo de aprendizado aos estudantes, pois a manipulação de objetos em ambiente com projeção tridimensional requer o manuseio de uma quantidade maior de comandos, bem 
como comandos mais sofisticados, como, por exemplo, àqueles que produzem textura, sombra e profundidade nos objetos.

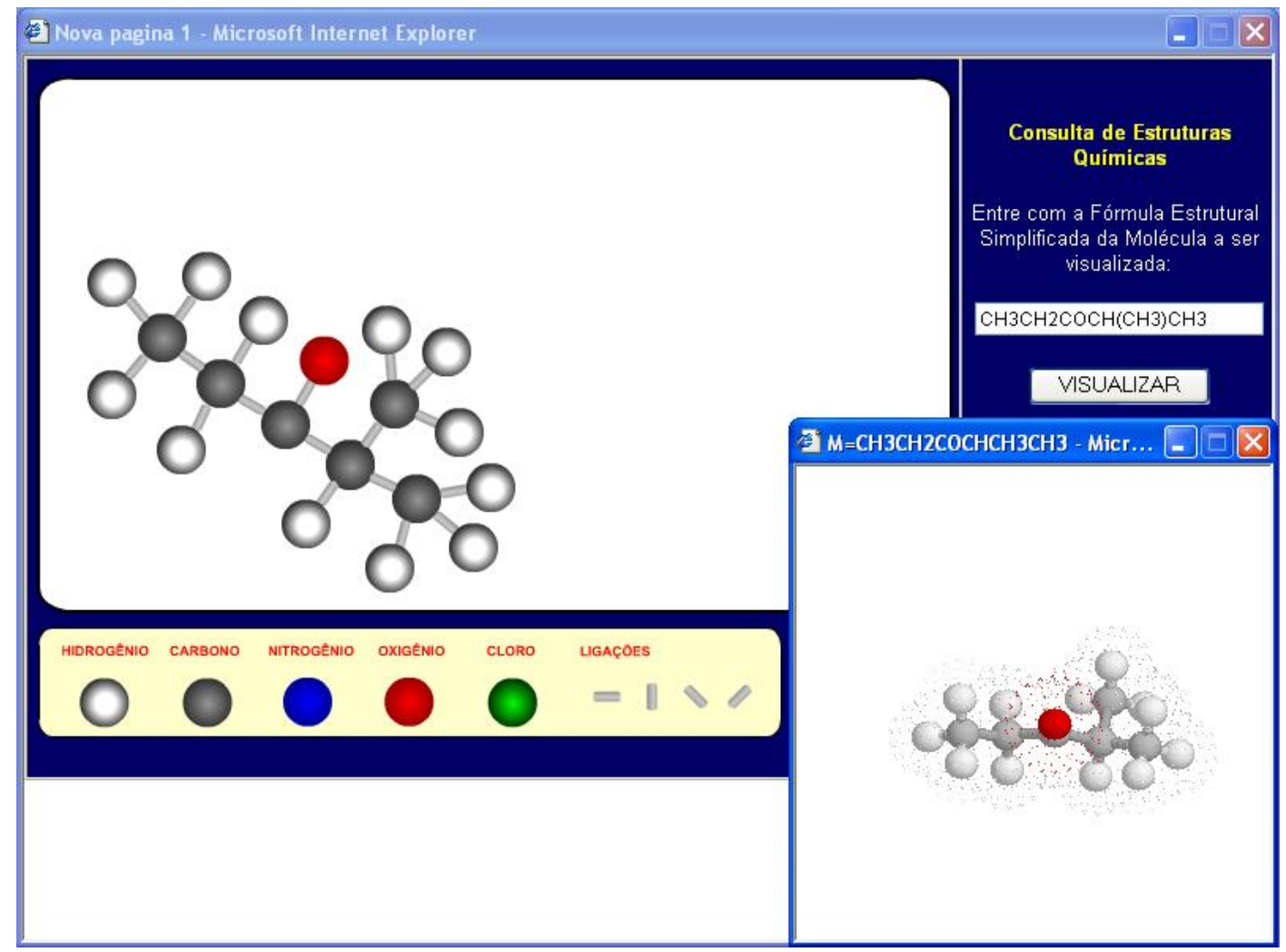

Figura 6: A figura representa a interface gráfica de animação do programa Construtor.

As bolas virtuais, que simbolizam os átomos, são apresentadas em diferentes colorações no padrão CPK, de modo a oferecer ao estudante diferentes tipos atômicos. Escolhemos este padrão de coloração pelo fato de o mesmo ser utilizado por grande parte dos sistemas de visualização empregados em livros e aplicativos. Os próprios modelos concretos tipo bolavareta utilizados em situações de sala de aula, foram fabricados com base neste padrão de cores, o que favorece a correlação entre os objetos moleculares concretos e virtuais.

Os objetos moleculares que representam as ligações químicas virtuais são bastões de tamanhos idênticos, porém estão dispostos espacialmente em quatro posições diferentes. Qualquer uma destas ligações químicas pode ser rotacionada em trezentos e sessenta graus, de forma a tomar o posicionamento apropriado, de acordo com o ponto de vista dos estudantes. 
Optamos em oferecer estes objetos em quatro posicionamentos diferentes para permitir ao estudante selecionar aquele que mais se aproxima da posição que ele necessita para construir suas representações. Também escolhemos restringir a um único tamanho estes objetos, porque o objetivo da atividade durante a utilização deste ambiente está focado na visualização das posições relativas dos átomos, bem como da ordem de ligação.

A manipulação destes objetos moleculares virtuais, através de animações gráficas, retém a simplicidade e conveniência da manipulação dos objetos moleculares concretos já utilizados, com a vantagem da possibilidade de construção de moléculas de qualquer tamanho. Nesta interface os estudantes podem mover livremente cada um dos objetos que simbolizam os átomos e ligações químicas pela tela do computador. Apesar disto, como os estudantes já manipularam os objetos moleculares concretos, eles têm a tendência de agrupar os objetos bidimensionais que simbolizam os átomos e ligações químicas numa disposição próxima àquela que mimetiza o posicionamento relativo tridimensional.

\section{Simulação}

A construção dos objetos moleculares virtuais através do ambiente de simulação é operacionalmente simples, pois requer que o estudante apenas digite uma seqüência de letras e números correspondentes à fórmula estrutural condensada de uma molécula orgânica, e escolha uma forma de representação entre as disponíveis (bola-vareta, espaço preenchido, traço, esqueleto e nuvem eletrônica). Em seguida, o estudante deve pressionar o botão esquerdo do mouse sobre a opção "construir", oferecida logo abaixo do campo onde digita a fórmula estrutural condensada da molécula em questão. Conforme descrito em materiais e métodos, esta seqüência de letras e números é enviada ao nosso computador servidor, o qual gera um arquivo contendo as coordenadas tridimensionais geometricamente otimizadas da molécula em questão. O computador servidor devolve este arquivo ao navegador do usuário, que pode visualizar o objeto molecular caso o plug-in de visualização. Para o uso do ambiente descrito neste trabalho sugerimos o plug-in de visualização oferecido gratuitamente e disponível na internet. 
Apesar de ser operacionalmente simples, a utilização do ambiente de simulação requer operações mentais mais sofisticadas do que o ambiente de animação gráfica, uma vez que o estudante deve desenvolver um domínio da representação simbólica, pelo fato de a interface de construção demandar seqüências de letras e números corretas, ou seja, que correspondam a uma molécula dentro dos padrões atualmente aceitos. Ao utilizar este ambiente o estudante é desafiado a visualizar moléculas a partir de seus nomes no padrão IUPAC ${ }^{1}$, de forma que os mesmos têm oportunidade de exercitar a representação da fórmula estrutural a partir do nome, e também têm oportunidade de verificar se sua representação corresponde ao modelo aceito.

Ao manipular objetos moleculares virtuais tridimensionais o estudante pode explorar o objeto molecular sob diversas perspectivas com o auxílio do mouse, mimetizando a forma como se manipula os objetos moleculares concretos. Isto faz com que os estudantes criem uma correlação entre o mundo concreto e o virtual, o que pode tornar mais estreita a correlação entre suas imagens mentais e as representações simbólicas e objetos moleculares concretos e virtuais. Além de visualizar a fórmula estrutural em três dimensões, é possível medir os ângulos e distâncias de ligação no objeto molecular virtual. Isto é possível graças a uma opção presente no plug-in de visualização. Com isso o estudante pode comparar, por exemplo, os comprimentos de ligação das ligações simples e insaturadas, o que não é possível em um ambiente de animação gráfica ou com os objetos concretos. Além disso, o estudante pode comparar os diferentes volumes atômicos dos átomos e grupos atômicos presentes na molécula, o que também não é possível com o uso de animações.

Desta forma, ambientes que possibilitem o contato do estudante com simulações favorecem o aprofundamento de conceitos que podem ser introduzidos a partir de representações menos sofisticadas, como o de ligações químicas.

\section{2 - Captura de vídeo digital no ensino}

A imagem e o áudio têm ocupado cada vez mais espaço na constituição e expressão do conhecimento humano, seja no âmbito da informação, do

1 Refere-se a International Union of Pure and Applied Chemistry. 
entretenimento e, mais atualmente, da educação. As informações mais precisas e ricas trazidas na forma audiovisual já são preferidas pelas novas gerações há algum tempo, em detrimento da palavra escrita [LÉVY, 1998]. O surgimento e disponibilidade do computador certamente podem contribuir para impulsionar o letramento científico no que se refere ao caráter prevalente da visualização para a tessitura do conhecimento [GIORDAN e GOIS, 2004]. Atualmente é possível dispor de formas de representação audiovisual integradas a outras linguagens, ou formas de expressão - como se queira, nas situações de aprendizagem em sala de aula, em razão de uma característica determinante das tecnologias da informação e comunicação, que é o fenômeno da convergência das mídias.

É neste sentido que chamamos a atenção para as formas de interação que ocorrem em situações de uso do computador, especialmente para finalidades de ensino e aprendizagem. Interações desta natureza, que se desenvolvem em um cenário multimediatizado, são tão novas quanto importantes para se compreender os limites e as possibilidades de uso do computador. Para levar adiante investigações que nos indiciem modos de ação, estilos de conversação, meios mediadores e suas funções, é necessário registrar adequadamente as situações de trabalho neste cenário multimediatizado. Em decorrência de um desdobramento direto da convergência de mídias, o computador torna-se estação de e para registro do trabalho, simultaneamente, o que nos permite superar dificuldades com a integração dos meios usuais para os registros da voz, da imagem, do texto.

Usualmente na realização de atividades com o auxílio do computador, a tela é um dos principais focos de interesse para o registro da situação. É dela que os usuários obtêm informações visuais. Indiretamente, a tela é também meio de apresentação da informação escrita. Portanto, o registro das ações que ali se passam faz-se tão necessário quanto qualquer outro registro. $\mathrm{O}$ registro da tela é o primeiro passo para caracterizar as situações de trabalho diante do computador.

Uma importante ferramenta já disponível é a gravação das imagens resultantes da tela em uso em uma quantidade de quadros por segundo suficiente para ser visualizada na forma de filme das ações do usuário. Existem 
softwares gratuitos que podem ser obtidos na internet que realizam esta tarefa mesmo em computadores com baixa capacidade de processamento. Os sistemas operacionais Windows ${ }^{\circledR}$ versão $X P ®$ já vem com esta opção no conjunto de programas básicos. As informações obtidas com este tipo de investigação serão quais sítios o estudante navegou, de que forma escreveu seus textos, ou como utilizou determinado programa no computador.

O segundo passo para caracterizar situações de trabalho diante do computador é registrar as ações que ocorrem fora da tela. Neste aspecto, já é bastante longa a experiência com as filmagens de salas de aula ou mesmo laboratórios, mas não com filmadoras em formato digital, que são essenciais quando se pensa em armazenar e editar dados com o auxílio do computador. A captura de vídeo pelo computador é hoje uma tarefa relativamente simplificada e que demanda máquinas razoavelmente robustas. Há pouco mais de cinco anos, este tipo de tarefa era algo muito complicado e da alçada das estações de trabalho de grande porte com capacidade de processamento fora do alcance de computadores de uso pessoal.

Sendo possível caracterizar de forma dupla as situações de trabalho diante do computador, ou seja, as ações que são mostradas na tela do computador em uso e as ações dos estudantes diante do computador, a combinação destes destas duas perspectivas da atividade de ensino pode trazer importantes informações a respeito tanto do uso do equipamento e dos programas para o âmbito educacional, quanto da natureza deste tipo de atividade e de que forma se dá a sua contribuição para o ensino de ciências.

Um dos problemas decorrentes do trabalho com diferentes dispositivos de captura, no caso um deles para a gravação da tela do computador e outro para gravar as ações dos estudantes, o que resulta em diferentes formatos de arquivos de vídeo, é a sincronização das linhas de tempo dos eventos registrados. Para que possa ser possível uma visualização paralela e conjunta dos arquivos resultantes, é necessário gastar considerável quantidade de tempo para sincronizar duas cenas de um mesmo evento e pode-se incorrer em imprecisão aumentando ou diminuindo a diferença do início das capturas a partir de dispositivos distintos. Além disso, cada sistema em separado possui seus próprios mecanismos de reprodução de vídeo, em diferentes velocidades 
e qualidades de apresentação, de forma que, mesmo que inicialmente não se perceba diferença de sincronização, ao longo de pouco tempo a diferença se torna nítida. Assim, uma característica necessária de um sistema que captura e armazena arquivos de imagem e som de duas diferentes perspectivas simultaneamente, é dotá-lo de sincronicidade, de forma a obter registros de igual formato e com a mesma linha de tempo.

Desenvolvemos um sistema de captura simultânea de vídeo que é executado durante a utilização de um sistema operacional Windows $X P ®$, no próprio computador utilizado pelo aluno. Para a utilização do sistema é necessário apenas um computador e uma webcam, além dos programas computacionais descritos abaixo. Como resultado, obtivemos vídeos do usuário e da tela do computador, e que podem ser vistos simultaneamente e de forma sincronizada em uma mesma tela.

Uma importante característica deste novo sistema é a portabilidade, uma vez que o sistema de gravação de vídeo é o próprio computador em uso pelo estudante, de forma que o mesmo pode ser facilmente transportado em um computador tipo laptop para escolas e laboratórios de investigação. Isso resulta em mais espontaneidade na situação de aprendizado, já que não são incluídos objetos estranhos nas proximidades do estudante durante 0 uso do computador. Com este sistema podemos realizar estudos sobre a usabilidade de softwares educacionais já conhecidos e de novos sistemas. Com isso será possível estudar a contribuição do uso de determinados softwares e mesmo aperfeiçoar sistemas que apresentem características de pouca contribuição no aprendizado.

\subsection{1 - Captura sincronizada de vídeo}

O sistema de captura simultânea [GIORDAN e GOIS, 2006] foi desenvolvido para ser executado em um computador tipo PC utilizando o sistema operacional Windows $\mathrm{XP} \circledast$, com o auxilio de dois programas obtidos comercialmente. O primeiro deles, o Camtasia Studio ${ }^{\mathrm{TM}}$, é utilizado como uma câmera interna ao computador, e faz a captura das imagens da tela de trabalho do usuário. A opção pela utilização deste programa se deve ao fato de o mesmo publicar as imagens obtidas em uma variável de ambiente do sistema 
operacional Windows ${ }^{\circledR}$. Esta funcionalidade, conforme descrito mais adiante, possibilita a gravação simultânea da captura de tela e de uma câmera conectada ao computador.

O segundo programa é o Helix ${ }^{\mathrm{TM}}$ Producer Plus, que, a partir de dispositivos de captura de áudio e vídeo conectados ao computador, gera os respectivos arquivos de vídeo sem o uso de sua interface gráfica. Isto é possível porque este programa faz uso de arquivos de configuração que contém as informações que possibilitam a execução de sessões paralelas e independentes de gravação, no caso dos vários tipos de dispositivo conectados ao computador, seja de gravação de dados da tela ou externos ao computador. Nestes arquivos estão armazenadas informações sobre o dispositivo a ser utilizado, como a taxa de amostragem do arquivo final, a quantidade de pixels por quadro, e outras informações sobre a qualidade do arquivo audiovisual. Esta é uma grande vantagem deste programa, uma vez que interfaces gráficas consomem boa parte da capacidade de processamento de um computador, o que também ajuda na gravação de imagens de mais de um dispositivo simultaneamente. Além desta importante funcionalidade, o programa pode ser executado paralela e independentemente a outras execuções dele mesmo.

Existem duas opções de dispositivos externos de captura, que dependem do tipo de câmera de vídeo utilizada. Se a câmera possuir apenas saídas analógicas de áudio e vídeo, deverá ser usada uma placa conversora no computador, a qual possibilitará a digitalização do vídeo obtido pela câmera e sua gravação no computador. Se a câmera possuir saídas digitais, do tipo USB ${ }^{\circ}$ ou Fire-Wire ${ }$, este mesmo tipo de entrada deve estar presente no computador para que o mesmo possa receber os dados da câmera. Utilizamos em nosso trabalho as portas USB como entrada de vídeo, a partir de uma webcam. Na fase inicial deste trabalho utilizamos uma placa conversora analógico-digital para obter imagens a partir de uma câmera com saída analógica. Pudemos perceber que o uso de câmeras com saída analógica aumenta consideravelmente o tempo de atraso quando da inicialização do sistema, o que prejudica a sincronização inicial dos arquivos de vídeo resultantes. 
Inicialmente fizemos a captura simultânea de dois dispositivos de vídeo: da imagem da tela obtida pelo usuário, juntamente com uma câmera externa posicionada de modo a captar as imagens da face e gestos do mesmo, conforme Figura 7. Esta configuração foi utilizada porque reúne, de forma abrangente, as informações sobre o trabalho realizado pelo estudante e suas ações diante do computador, e não demanda muita capacidade de processamento, podendo ser efetuada em um computador com $1.6 \mathrm{GHz}$ de velocidade de processador.

O sistema descrito neste trabalho pode utilizar mais dispositivos de vídeo (câmera ou programa de captura de tela) simultaneamente, dependendo da capacidade de processamento e da quantidade de portas de entrada e saída (como, por exemplo, portas tipo USB) do computador onde a captura será efetuada. Testamos o sistema com 3 dispositivos de vídeo funcionando simultaneamente (Figura 8).

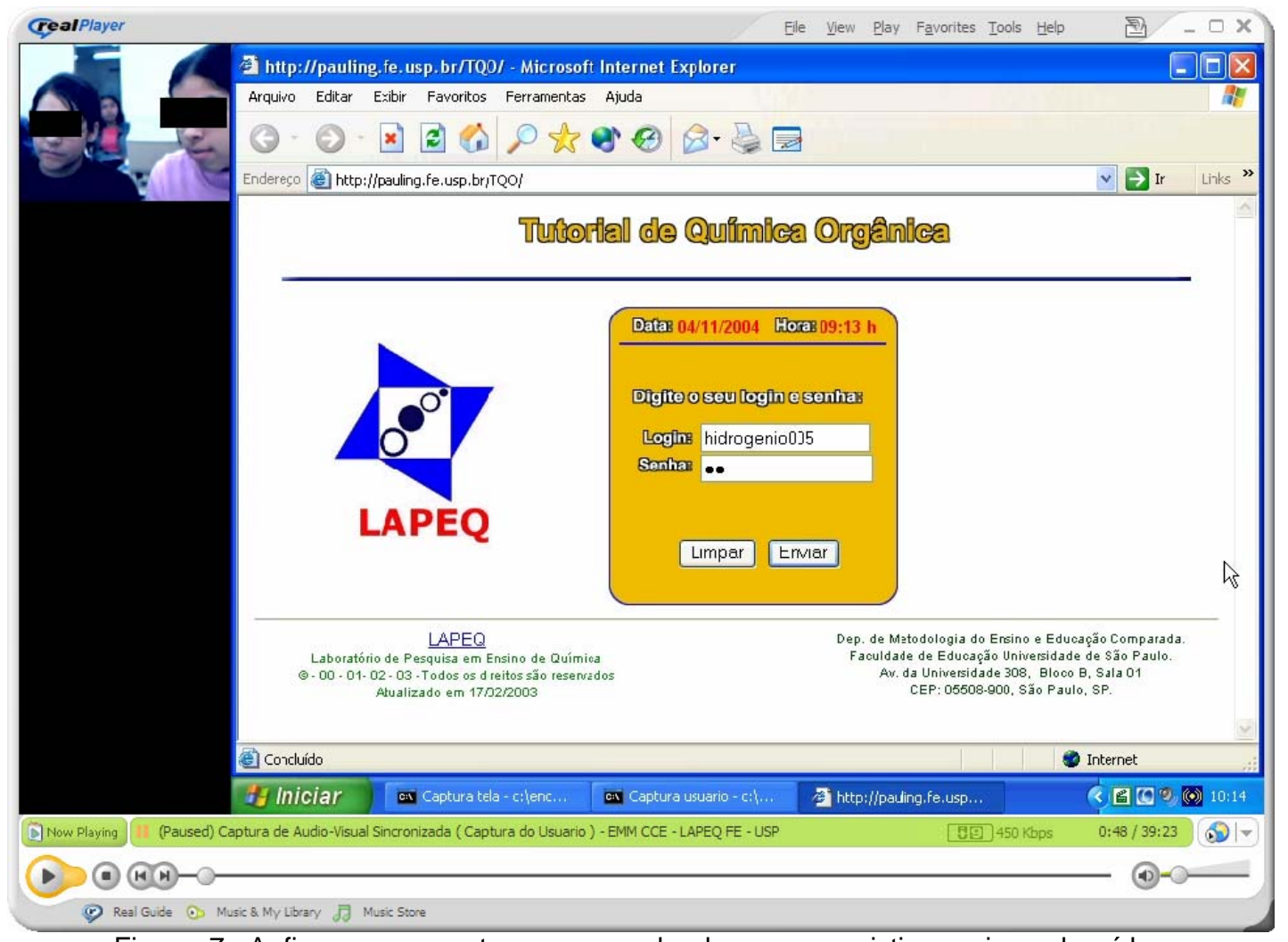

Figura 7. A figura representa um exemplo de como assistir arquivos de vídeo resultantes do sistema de captura sincronizada com dois dispositivos de vídeo. 
Neste caso é necessário maior velocidade de processamento (acima de $2 \mathrm{GHz}$ ), caso contrário os vídeos obtidos terão menos de 15 quadros por segundo, o que resulta em qualidade muito abaixo da necessária para realizar qualquer estudo. O terceiro dispositivo foi utilizado para gravar imagens relativas à interação entre o usuário e o hardware, especialmente teclado, mouse e tela. Com esta configuração o sistema disponibiliza mais informações importantes sobre a situação de aprendizagem, já que muitas vezes, ao utilizar sistemas ou explorar ambientes desconhecidos, o usuário se refere aos objetos de exploração de forma indefinida, por exemplo, "isto", "aquilo", ou "este negócio". Com este terceiro dispositivo de imagem é possível saber a qual ponto da tela o usuário está se referindo.

\subsection{2 - Funcionamento do sistema}

Passaremos a descrever o funcionamento do sistema como um todo. A inicialização e controle do sistema de captura são executados por meio de um arquivo tipo lote (iniciar.bat) executado em uma janela de terminal do sistema operacional (Figura 9). Este arquivo inicia a execução independente do programa Helix ${ }^{\mathrm{TM}}$ Producer Plus para cada dispositivo de captura de vídeo. Os dispositivos já devem estar devidamente configurados com antecedência através de arquivos de configuração do programa Helix ${ }^{\mathrm{TM}}$ com extensão RPJF.

Cada execução independente do programa Helix ${ }^{\mathrm{TM}}$ converte as imagens capturadas dos dispositivos em arquivo de vídeo com extensão RM (Real Media). No caso de serem usados dois dispositivos de captura de vídeo, o programa Camtasia Studio ${ }^{\mathrm{TM}}$ funciona como um dispositivo de captura (câmera) interna, e envia as imagens da tela do usuário, através de uma variável do sistema, diretamente para uma das execuções simultâneas do

programa Helix TM. O outro dispositivo de captura, o externo, será uma webcam, que envia as imagens do próprio usuário para a outra execução simultânea do programa Helix ${ }^{\mathrm{TM}}$. 


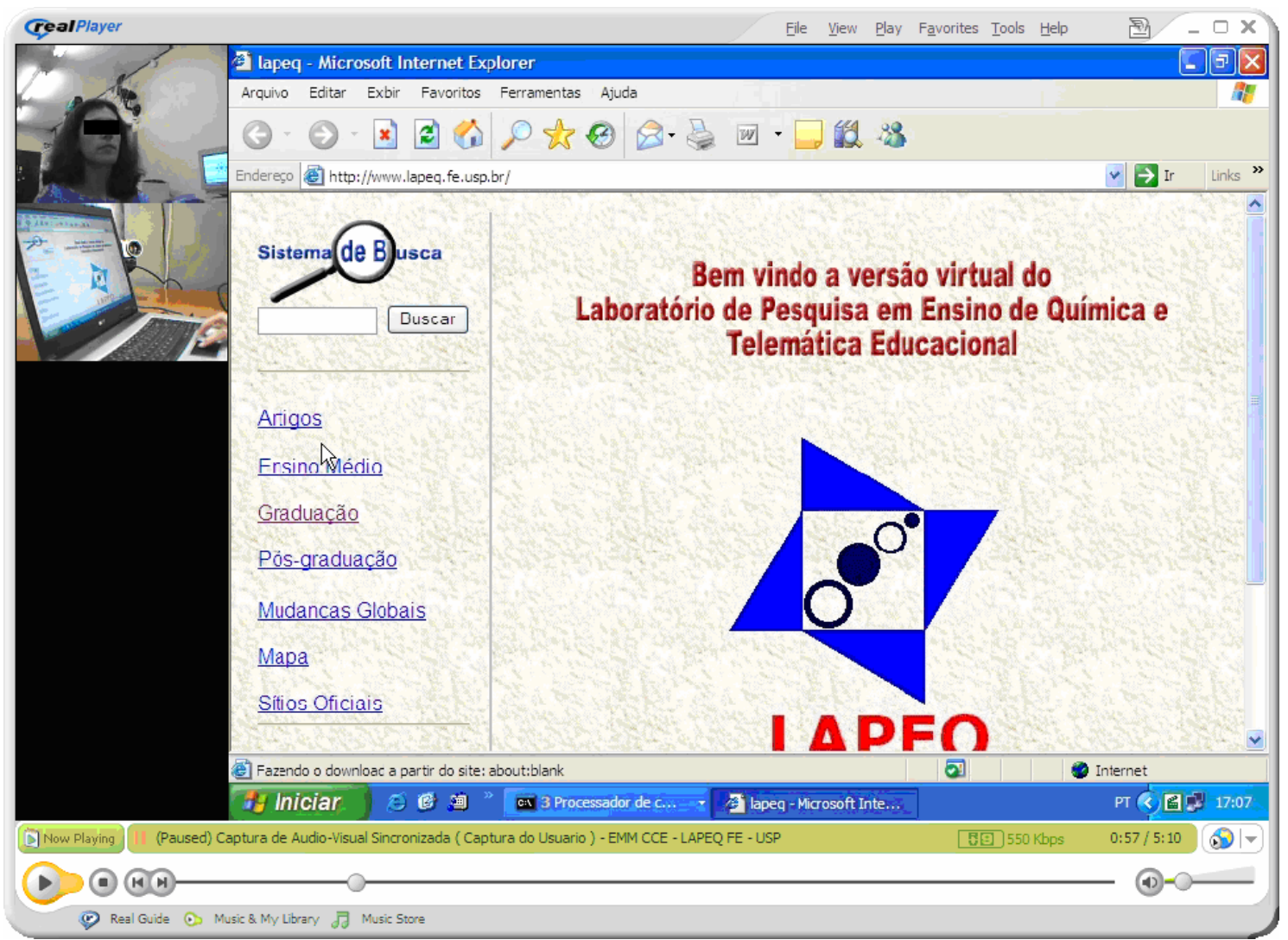

Figura 8. A figura representa um exemplo de como assistir os arquivos de vídeo resultantes do sistema de captura sincronizada com três dispositivos de vídeo.

O tamanho dos arquivos de vídeo obtidos na configuração que utilizamos foi em média de $2 \mathrm{MB}$ para cada minuto de gravação, por arquivo gerado, ou seja, $4 \mathrm{MB}$ para um conjunto de dois dispositivos (Figura 7) de vídeo. Se utilizássemos 3 dispositivos simultâneos (Figura 8) teríamos $6 \mathrm{MB}$ por minuto gravado. Este tamanho de arquivo é compatível com a duração de uma aula ou seqüência de ensino, e com o tamanho dos discos rígidos comercialmente disponíveis na atualidade, sendo possível também o uso de discos rígidos externos quando for necessário mais tempo de gravação. É possível aumentar ou diminuir o tamanho dos vídeos, e, portanto, proporcionalmente sua qualidade, modificando os arquivos de configuração do programa Helix ${ }^{\text {TM }}{ }^{1}$. 


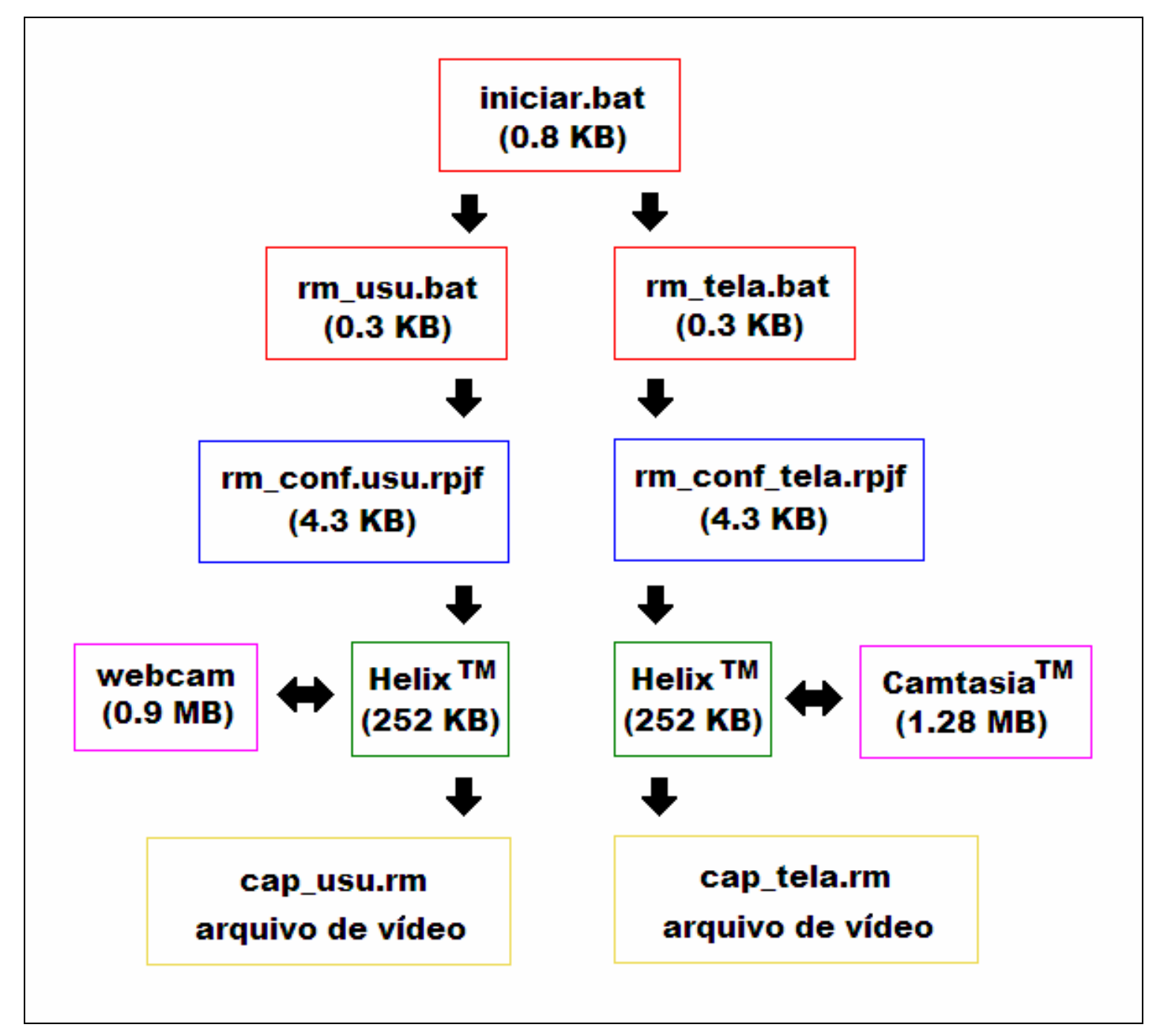

Figura 9. Fluxograma do funcionamento do sistema de captura sincronizada. $O$ tamanho de cada arquivo e programa está indicado entre parênteses. O tamanho dos arquivos de vídeo dependerão da quantidade de tempo que será realizada a captura de imagens.

Para colocar o sistema em funcionamento é necessário iniciar manualmente o programa Camtasia Studio TM e conectar a webcam ao computador. Até o momento não descobrimos uma forma de iniciar este programa automaticamente no processo. A partir daí é necessário apenas iniciar o arquivo tipo lote e o restante do processo será executado automaticamente. É importante ajustar com antecedência a posição da webcam para garantir que o usuário esteja adequadamente enquadrado na imagem a ser gravada. 


\subsection{3 - Instalação do sistema}

Para que o sistema funcione adequadamente, na configuração que utilizamos, devem ser instalados os programas Camtasia Studio ${ }^{\mathrm{TM}}$ e Helix $^{\mathrm{TM}}$ Producer Plus. O primeiro pode ser instalado com suas configurações padrão, e deve ser conferido se a opção de publicação ao vivo está habilitada. O segundo programa deve ser instalado em um subdiretório logo acima do diretório raiz. A instalação deste segundo programa deve ser feita desta forma para facilitar a execução do programa Helix ${ }^{\text {TM }}$ a partir de seus arquivos de configuração. Deve ser criado também um outro subdiretório a partir do diretório raiz para que os arquivos de vídeo sejam gerados, pelo mesmo motivo anterior. A partir daí devem ser gerados os arquivos de configuração para cada dispositivo de vídeo individualmente, e então o sistema está pronto para ser executado.

\subsection{4 - Como assistir os vídeos resultantes}

No sistema descrito neste trabalho, os vídeos resultantes estão em formato Real Media ${ }^{\mathrm{TM}}$. Estes arquivos podem ser visualizados através do programa Real Player ${ }^{\mathrm{TM}}$, distribuído gratuitamente na internet. Os arquivos de vídeo podem ser vistos em uma mesma tela por meio de uma sessão SMIL de arquivos no formato Real MediaTM (Figuras 7 e 8), que é um formato de exibição de arquivos com extensão RM. Com isso os movimentos na área de trabalho da tela do computador e as ações do usuário podem ser vistos simultaneamente, já que os dois vídeos foram gravados de forma sincrônica e estão sendo executados no mesmo dispositivo, que é o computador onde se assiste aos vídeos. Adicionalmente, a fala dos usuários pode ser transcrita e exibida na mesma tela junto com os vídeos da tela do computador e do usuário, na mesma sessão smil. A organização dos dados em uma mesma tela é importante para a descrição pormenorizada dos eventos ocorridos na situação de aprendizagem. A observação integrada de cada evento pode revelar detalhes que não foram detectados durante a interação do aluno com o sistema, o que contribuirá para elucidar aspectos a respeito da interação e do aprendizado. 
A composição múltipla de vídeos pode ser gravada em um DVD como se fosse um só arquivo, através de programas de conversão de formatos de vídeo, ou através de uma placa de captura. Isto possibilita a visualização do conteúdo em aparelhos de DVD domésticos, o que facilita o estudo da interação do usuário com o ambiente computacional, o software ou o conteúdo, ou mesmo composições destes. Desta forma pode ser feito uma descrição mais detalhada do conteúdo, já que os recortes dos episódios podem ser feitos na divisão do DVD em capítulos apropriados.

\section{3 - Grupo-foco dos testes do ambiente virtual}

Testamos o ambiente desenvolvido neste trabalho em duas ocasiões com dois grupos diferentes de estudantes do terceiro ano do ensino médio da E.E. "Jornalista David Nasser", localizada na região do Capão Redondo em São Paulo capital. Em ambas as ocasiões trouxemos os estudantes para uma sala de computadores com acesso a internet na Faculdade de Educação da USP (LIET), onde puderam trabalhar em duplas. Na primeira ocasião, em novembro de 2004, trouxemos um grupo de 30 estudantes, e na segunda ocasião, em novembro de 2005, trouxemos um grupo de 34 estudantes. Em ambas as turmas uma dupla diferente de estudantes foi escolhida como duplafoco para o teste do sistema de captura múltipla sincronizada de vídeo e avaliação da seqüência de ensino e suas ferramentas.

$\mathrm{Na}$ turma de 2005 os estudantes realizaram as atividades propostas no ambiente virtual em dois dias distintos na mesma semana. Um dos componentes da dupla-foco não pôde comparecer no segundo dia, de forma que a dupla-foco de 2005 teve três componentes. Tanto na dupla-foco de 2004 quanto na dupla-foco de 2005 a faixa etária dos estudantes foi de 17 a 18 anos de idade. Na dupla foco de 2004 tivemos dois meninos realizando as atividades, enquanto que na dupla-foco de 2005 tivemos uma menina e um menino nos dois dias de atividade.

Os resultados da turma de 2004 serviram para confirmar a estabilidade do sistema de captura, uma vez que a captura sincronizada de vídeo é feita concomitantemente com a utilização do computador pelos estudantes para a realização das atividades. Os resultados da turma de 2005 serão analisados 
neste trabalho no próximo capítulo. Em ambos os testes de usabilidade as turmas foram acompanhadas por mim, uma vez que eu fui ao mesmo tempo o desenvolvedor do ambiente e também professor das turmas na respectiva escola.

\section{4 - Questionário}

Após a realização das atividades de ensino com a turma de alunos de 2005, solicitamos que os mesmos respondessem um questionário com dez perguntas a respeito da utilização do ambiente virtual descrito neste trabalho. Após dois períodos de duas horas de utilização do sistema, os 34 estudantes responderam as perguntas do questionário acerca do seu interesse pelo sistema, da dificuldade de uso do mesmo e da utilidade dos objetos moleculares virtuais e concretos fornecidos durante a utilização do mesmo, sendo que a última questão pedia sugestões a respeito de uma possível melhoria do ambiente e da realização das atividades, a qual não será analisada neste trabalho. O questionário, que pode ser visto na íntegra no Anexo 2 deste trabalho, foi composto por seis perguntas com respostas de múltipla escolha na forma de escala Likert de cinco pontos e quatro perguntas do tipo aberta, onde o estudante pôde expressar livremente suas idéias e opiniões. Foi pedido aos estudantes que não se identificassem no questionário.

\section{5 - Entrevista}

Após a aplicação do questionário do Anexo 2 em toda a turma de 2005, entrevistamos cada um dos três estudantes que fez parte da dupla-foco, identificados como F, S e J, que haviam utilizado o sistema de captura múltipla e sincronizada de vídeo. As entrevistas foram realizadas num formato estruturado, uma vez que já havíamos selecionado previamente algumas perguntas para serem feitas aos estudantes, e as perguntas foram feitas exatamente na ordem descrita abaixo. A Tabela 6 mostra as perguntas que foram feitas aos três estudantes.

Antes de entrevistarmos os estudantes, selecionamos alguns trechos de vídeo, referentes às situações onde julgamos ter havido mudança de interesse por parte dos mesmos, e mostramos para os próprios estudantes. Para cada estudante foram mostrados diferentes conjuntos de extratos. Em seguida entrevistamos individualmente cada estudante, perguntando sobre o interesse naquela situação 
específica, conforme as questões relacionadas na Tabela 6. Consideramos situações onde houve mudança de interesse aquelas em que foi percebido modificações da tonalidade de voz ou posicionamento físico frente às atividades.

\begin{tabular}{|l|l|}
\hline Pergunta & Enunciado da pergunta \\
\hline 1 & O que chamou a sua atenção neste ponto? \\
\hline 2 & $\begin{array}{l}\text { Qual era o seu grau de interesse naquele momento? } \\
(1=\text { nenhum interesse; } 2=\text { pouco interesse; } 3=\text { algum } \\
\text { interesse; } 4=\text { muito interesse; } 5=\text { total interesse })\end{array}$ \\
\hline 3 & $\begin{array}{l}\text { Porque estava muito interessado? (ou pouco } \\
\text { interessado) }\end{array}$ \\
\hline 5 & $\begin{array}{l}\text { Qual foi a sua sensação nesta hora? } \\
\text { muito difícil; } 2 \text { = difícil; 3 = normal; 4 = fácil; 5 = muito } \\
\text { fácil) }\end{array}$ \\
\hline
\end{tabular}

Tabela 6. A tabela mostra as perguntas feitas aos estudantes da dupla-foco na entrevista semi-estruturada realizada após os mesmos assistirem alguns trechos do vídeo resultante da realização das atividades de ensino com o Construtor.

Gravamos o áudio da entrevista, e transcrevemos alguns trechos que destacam a potencialidade do ambiente para o desenvolvimento de habilidades de representação estrutural química, junto com a análise dos mesmos. 


\section{4 - DADOS E DISCUSSÃO}

\section{1 - Questionário}

Analisamos abaixo as respostas obtidas com os resultados dos questionários da turma de 2005 por ordem das questões. Nas questões em formato de escala Likert de cinco pontos apresentamos os gráficos e tabelas relativas às porcentagens de resposta de cada categoria da escala, enquanto que nas respostas abertas procuramos agrupar as respostas em categorias e citar alguns exemplos de respostas. Antes da análise dos resultados de cada pergunta colocamos integralmente o enunciado da própria questão.

\section{Perguntas 1,2 e 3}

As perguntas 1, 2 e 3 serão analisadas conjuntamente pelo fato de serem perguntas relacionadas ao interesse do estudantes sobre determinados temas e porque a comparação dos dados das mesmas em um mesmo gráfico resulta em uma forma interessante de visualização destes dados. Estes dados se referem à turma de 2005, onde obtivemos um total de 34 questionários respondidos. As três perguntas foram respondidas no formato de escala Likert de 5 pontos $^{1}$, e os resultados podem ser vistos em formato gráfico na Figura 10. Descrevemos abaixo integralmente o enunciado das primeiras três questões.

\section{Enunciado da questão 1}

Do ponto de vista do seu interesse, as aulas de química em sua escola, da forma como são ministradas têm:

\section{Enunciado da questão 2}

Do ponto de vista do seu interesse, o tema petróleo, de forma geral, é de:

11 = nenhum interesse; 2 = pouco interesse; 3 = algum interesse; 4 = muito interesse; 5 = total interesse. 


\section{Enunciado da questão 3}

Do ponto de vista do seu interesse, a forma como você trabalhou nesses dois dias aqui no laboratório de informática lhe proporcionaram:

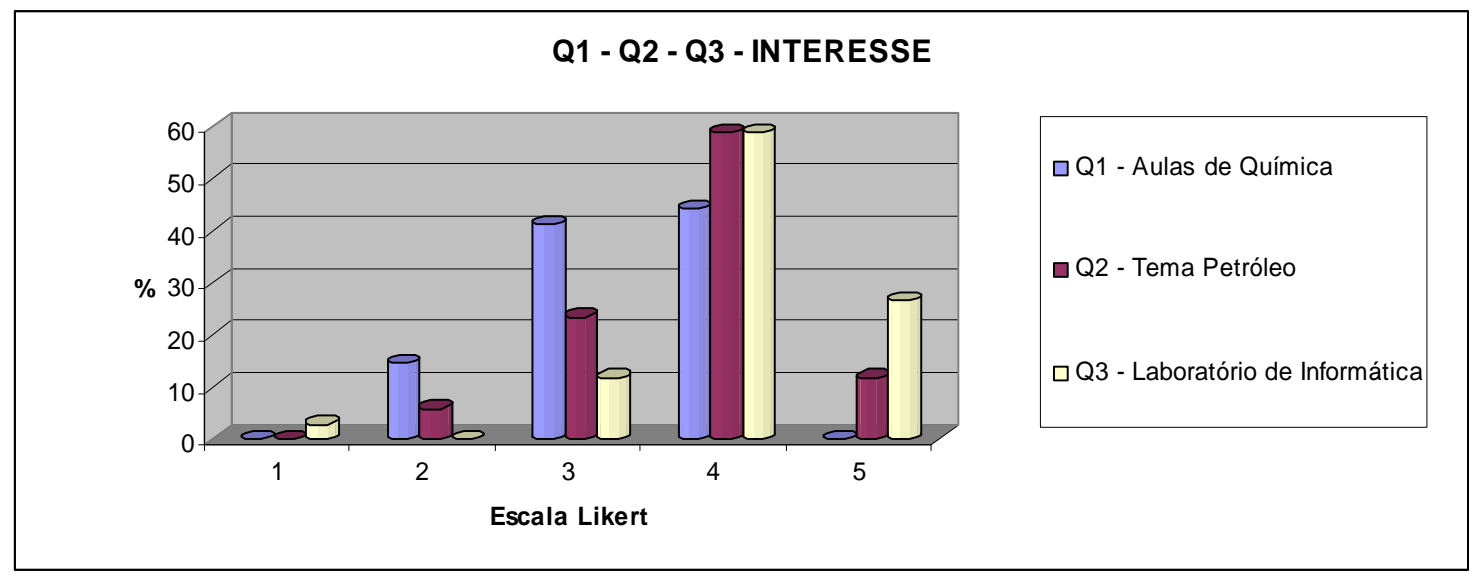

Figura 10. Gráfico demonstrativo dos resultados das questões 1, 2 e 3 do questionário.

Nas primeiras três questões os estudantes são perguntados sobre o seu interesse nas aulas de química ministradas normalmente no período escolar do ano de 2005, sobre o interesse no tema petróleo, e sobre o interesse dos alunos nas aulas do laboratório de informática para a utilização do ambiente de ensino descrito neste trabalho.

Na primeira pergunta (Tabela 7 e Figura 10), a respeito das aulas de Química que ocorreram cotidianamente no ambiente escolar, $14,7 \%$ dos estudantes responderam que tinham pouco interesse nas aulas, enquanto que $44,2 \%$ responderam que tinham algum interesse nas aulas e 44,1\% dos estudantes responderam que tinham muito interesse nas aulas. Se somarmos as respostas dos estudantes das duas categorias com maior número de respostas, ou seja, "algum interesse" e "muito interesse" nas aulas de Química, teremos um total de $85,5 \%$ de alunos.

Como eu mesmo era o professor dos estudantes, talvez o fato de ter levado os mesmos para a realização das atividades em um ambiente virtual na Universidade de São Paulo tenha interferido positivamente nas respostas dos mesmos. De qualquer forma, desde o início do ano escolar houve boa disposição entre os estudantes e o professor no decorrer das aulas e das 
outras atividades que tiveram lugar no ambiente escolar, o que certamente também contribuiu para as respostas positivas a respeito das aulas de Química, uma vez que o desenvolvimento de emoções positivas entre estudantes e professores contribui de maneira substancial para o interesse nas aulas.

$\mathrm{Na}$ segunda pergunta (Tabela 7 e Figura 10), a respeito do tema petróleo, 5,9\% dos estudantes responderam que tinham pouco interesse pelo tema, enquanto que $23,5 \%$ responderam que tinham algum interesse e 58,8\% responderam que tinham muito interesse por este tema. Do total de alunos, 11,8\% responderam que tinham total interesse pelo tema petróleo. Se somarmos a porcentagem de alunos das categorias com maior quantidade de respostas, ou seja, "algum interesse" e "muito interesse" teremos um total de $82,3 \%$ de estudantes, fora os que responderam que tinham total interesse. Somando as categorias "algum interesse", "muito interesse" e "total interesse" chegaremos a $94,1 \%$ dos estudantes.

\begin{tabular}{|c|c|c|c|}
\hline $\begin{array}{c}\text { Q1 - Aulas } \\
\text { de Química } \\
\text { (\%) }\end{array}$ & $\begin{array}{c}\text { Q2 - Tema } \\
\text { Petróleo (\%) }\end{array}$ & $\begin{array}{c}\text { Q3 - Laboratório } \\
\text { de Informática } \\
\mathbf{( \% )}\end{array}$ & Escala Likert \\
\hline 0 & 0 & 2,9 & 1 - nenhum interesse \\
\hline 14,7 & 5,9 & 0 & 2 - pouco interesse \\
\hline 41,2 & 23,5 & 11,8 & 3 - algum interesse \\
\hline 44,1 & 58,8 & 58,8 & 4 - muito interesse \\
\hline 0 & 11,8 & 26,5 & 5 - total interesse \\
\hline
\end{tabular}

Tabela 7. A tabela mostra a porcentagem de respostas dos estudantes às perguntas 1,2 e 3 do questionário.

Começamos a estudar o tema petróleo com os estudantes com um mês de antecedência, ou 8 aulas de 50 minutos cada, de forma que os estudantes já tinham estudado aspectos da aplicação e importância do petróleo na atualidade. A introdução do tema a partir de assuntos correlacionados ao cotidiano dos estudantes certamente contribuiu para o aumento do interesse dos mesmos no tema petróleo.

Se compararmos as respostas das duas primeiras perguntas, observaremos um aumento do interesse dos estudantes na segunda pergunta. 
Na questão sobre as aulas cotidianas de Química não houve respostas na categoria "total interesse", enquanto que na pergunta sobre o tema petróleo houve um total de $11,8 \%$ nesta mesma categoria. Em ambas as perguntas as categorias que apresentam maior número de respostas são "algum interesse" e "muito interesse", o que representa $85,5 \%$ na primeira pergunta e $82,3 \%$ na segunda pergunta. Ao mesmo tempo ocorre diminuição de respostas na categoria "pouco interesse" da pergunta 1 para a pergunta 2, de 14,7\% para $5,9 \%$, o que sugere que o tema petróleo realmente aumente o interesse dos estudantes pela aula.

$\mathrm{Na}$ terceira pergunta (Tabela 7 e Figura 10), a respeito do uso do laboratório de informática para a aula de Química, aparecem respostas na categoria "nenhum interesse", num total de 2,9\% das respostas (1 estudante), categoria que não teve resposta nas duas perguntas anteriores. Junto com isso, na categoria "pouco interesse" não houve respostas, sendo que nas perguntas anteriores, a respeito da aula cotidiana de química e do tema petróleo, as respostas foram de 14,7\% e 5,9\% respectivamente, o que denota mudança no grau de interesse cumulativo na introdução do tema petróleo e no uso do laboratório de informática. Na categoria "algum interesse" houve um de total de $11,8 \%$ de respostas, com diminuição da porcentagem de respostas em relação às duas perguntas anteriores, que perfazem 41,2\% e 23,5\% na mesma categoria. Na categoria "muito interesse" o total de respostas foi de 58,8\%, que é a mesma porcentagem de respostas da pergunta 2 , e maior que a resposta da pergunta 1, que é de 44,1\%.

Finalmente, na categoria "total interesse", houve um total de $26,5 \%$ das respostas, número este maior que na mesma categoria das respostas das duas perguntas anteriores, que perfazem 0\% e 11,8\%. Enquanto que nas perguntas 1 e 2 a maioria das respostas esteve nas categorias "algum interesse" e "muito interesse", a maioria das respostas na pergunta 3 esteve nas categorias "muito interesse" e "total interesse", neste caso num total de $85,3 \%$, o que indica claramente o aumento do interesse dos estudantes pela aula de Química quando a mesma é ministrada em um laboratório de informática.

Podemos inferir a partir destes resultados que o tema petróleo e o laboratório de informática despertaram mais interesse nos estudantes, em 
relação às aulas de química ministradas cotidianamente na sala de aula. Certamente a combinação destes dois componentes contribuiu para que os estudantes tivessem mais interesse em resolver as atividades propostas no ambiente virtual descrito neste trabalho.

\section{Questão 4}

A questão 4 se relaciona diretamente com as três primeiras questões, uma vez que depende diretamente das mesmas para a resposta. Foi pedido aos estudantes respostas do tipo aberta. O enunciado da questão está integralmente descrito abaixo.

\section{Enunciado da questão 4}

Comparando suas respostas para os itens 1 e 3 , relacione abaixo os fatores que te levaram a selecionar graus de interesse distintos ou idênticos.

Separamos as respostas abertas obtidas para esta questão em 3 categorias. A Figura 11 demonstra de forma gráfica os resultados obtidos para a questão 4. Na primeira categoria foram agrupamos as respostas onde 0 mudança de interesse estava relacionado ao ambiente virtual ou a metodologia computacional. Na segunda categoria foram agrupadas as respostas onde a mudança de interesse estava relacionada ao assunto petróleo e a utilidade do mesmo na sociedade (CTS).

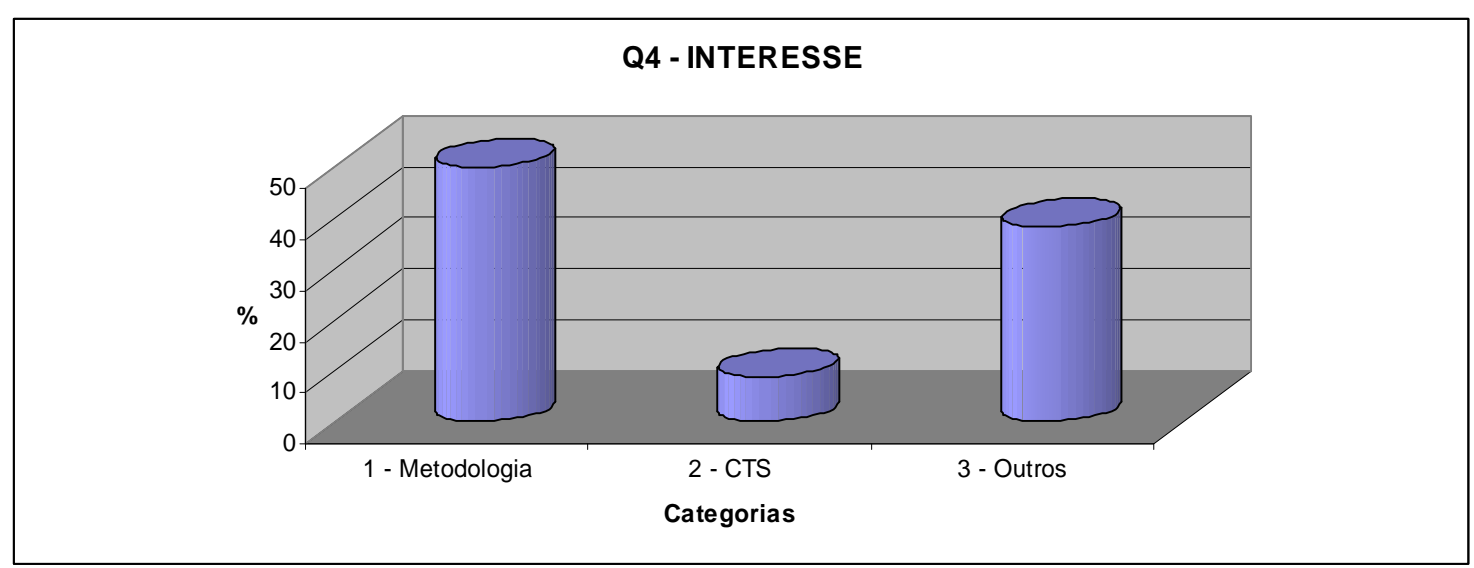

Figura 11. A figura representa o gráfico demonstrativo do resultado da pergunta 4 do questionário. 
$\mathrm{Na}$ terceira e última categoria foram agrupadas respostas em branco e outros motivos, como boa didática do professor, interesse em conhecer o ambiente universitário durante a visita, e outros. Obtivemos um total de 17 respostas (50\%) que relacionaram sua mudança de interesse com o ambiente virtual utilizado ou a metodologia computacional, e um total de 8,8\% de respostas que relacionaram sua mudança de interesse com o assunto petróleo e seu uso na sociedade. Na última categoria obtivemos um total de $38,2 \%$ das respostas. Relatamos abaixo duas respostas dadas pelos estudantes, as quais relacionam a sua mudança de interesse com o ambiente virtual ou a metodologia computacional.

Aluno 3: "Os programas de computadores são de alta resolução e bem bolado. A forma que as perguntas são fazem com que ficasse mais fácil".

Aluno 26: "Muito interessante em aulas práticas, computadorizadas fazendo exercícios com respostas que ajudam a resolver dúvidas em química".

Comparando os resultados desta questão com os resultados das três primeiras questões, temos uma inferência forte de que o ambiente virtual utilizado pelos estudantes aumenta o interesse dos mesmos no estudo da Química.

\section{Questão 5}

Na questão 5 perguntamos aos estudantes a respeito da operação do Construtor de Objetos Moleculares dentro do ambiente virtual descrito neste trabalho. Pedimos aos estudantes respostas dentro de uma escala tipo Likert de cinco pontos. Descrevemos abaixo integralmente o enunciado da questão, bem como os resultados obtidos.

\section{Enunciado da questão 5}

Especificamente sobre a operação do construtor, ou seja, a forma de utilizá-lo, você o considera: $(1=$ muito difícil; $2=$ difícil; $3=$ normal; 4 = fácil; 5 = muito fácil) 
A Figura 12 e a Tabela 8 demonstram os resultados da questão de número 5. Sobre a operação do programa Construtor, obtivemos um total de 2,9\% (1 estudante) das respostas na categoria 'muito difícil', e 11,8\% das respostas na categoria 'difícil'.

\begin{tabular}{|c|l|}
\hline \multicolumn{2}{|c|}{$\begin{array}{c}\text { Q5 - Operação do } \\
\text { Construtor }\end{array}$} \\
\hline 2,9 & 1 - muito difícil \\
\hline 11,8 & 2 - difícil \\
\hline 23,5 & 3 - normal \\
\hline 47,1 & 4 - fácil \\
\hline 14,7 & 5 - muito fácil \\
\hline
\end{tabular}

Tabela 8 - A tabela mostra os resultados da pergunta 5 do questionário.

Obtivemos também 23,5\% das respostas na categoria 'normal', 47,1\% de respostas na categoria 'fácil' e $14,7 \%$ de respostas na categoria 'muito fácil'. Se somarmos as duas categorias que tiveram o maior número de respostas, ou seja, 'normal' e 'fácil', teremos um total de $70,6 \%$ do total. Se somarmos as três categorias com maior número de respostas, ou seja 'norma', 'fácil' e 'muito fácil', teremos um total de $85,3 \%$ do total de respostas.

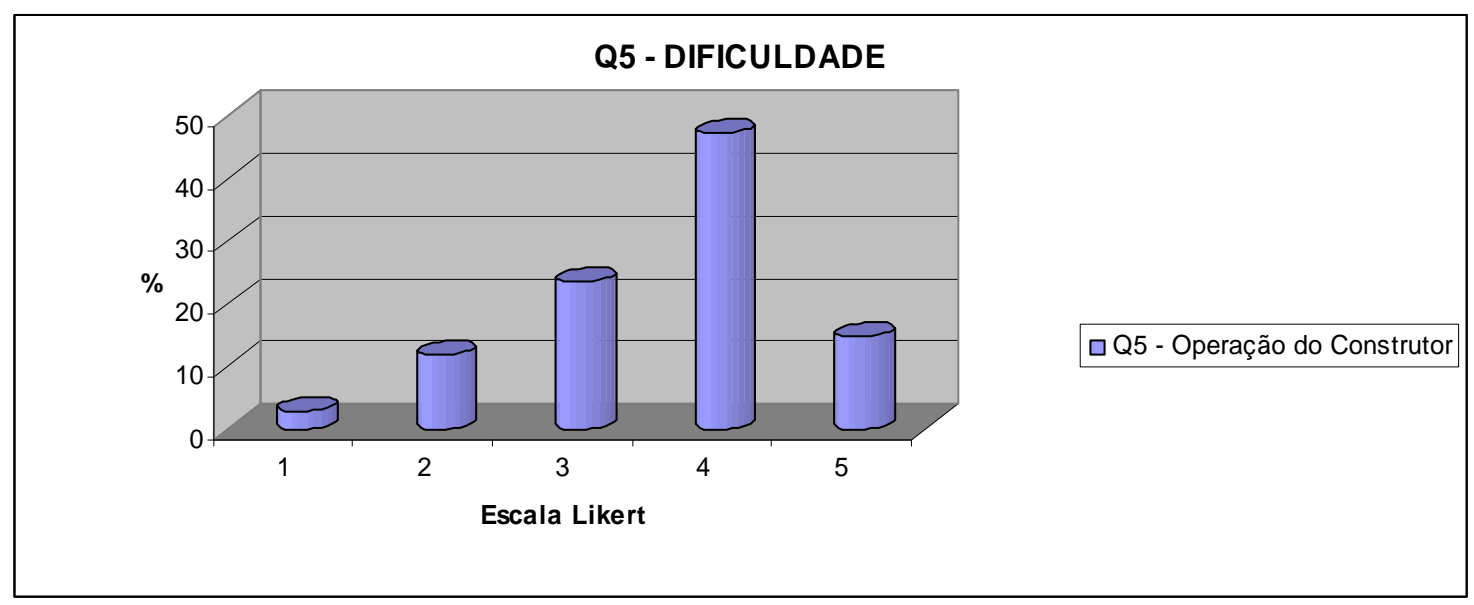

Figura 12. A figura mostra o gráfico demonstrativo do resultado da pergunta 5 do questionário. 
Podemos inferir deste resultado que a maioria dos estudantes (85.3\%) achou que o grau de dificuldade de operação do Construtor foi de normal a muito fácil.

\section{Questão 6}

Nesta questão pedimos para os estudantes descreverem os motivos que os levaram a selecionar o grau de dificuldade do programa Construtor como 'difícil' ou 'fácil'. Nesta questão os estudantes puderam colocar suas respostas de forma aberta. Descrevemos abaixo o enunciado da questão 6.

\section{Enunciado da questão 6}

Relacione abaixo os fatores que te levaram a selecionar o grau de dificuldade/facilidade na operação do construtor.

Também separamos as respostas de tipo aberta desta questão em três categorias. Na primeira delas agrupamos as respostas que relacionaram a facilidade na operação do construtor com relação à visualização de objetos moleculares. Na segunda categoria agrupamos as respostas que relacionaram a facilidade de uso do construtor com a simplicidade de operação ou por se tratar de um ambiente computacional.

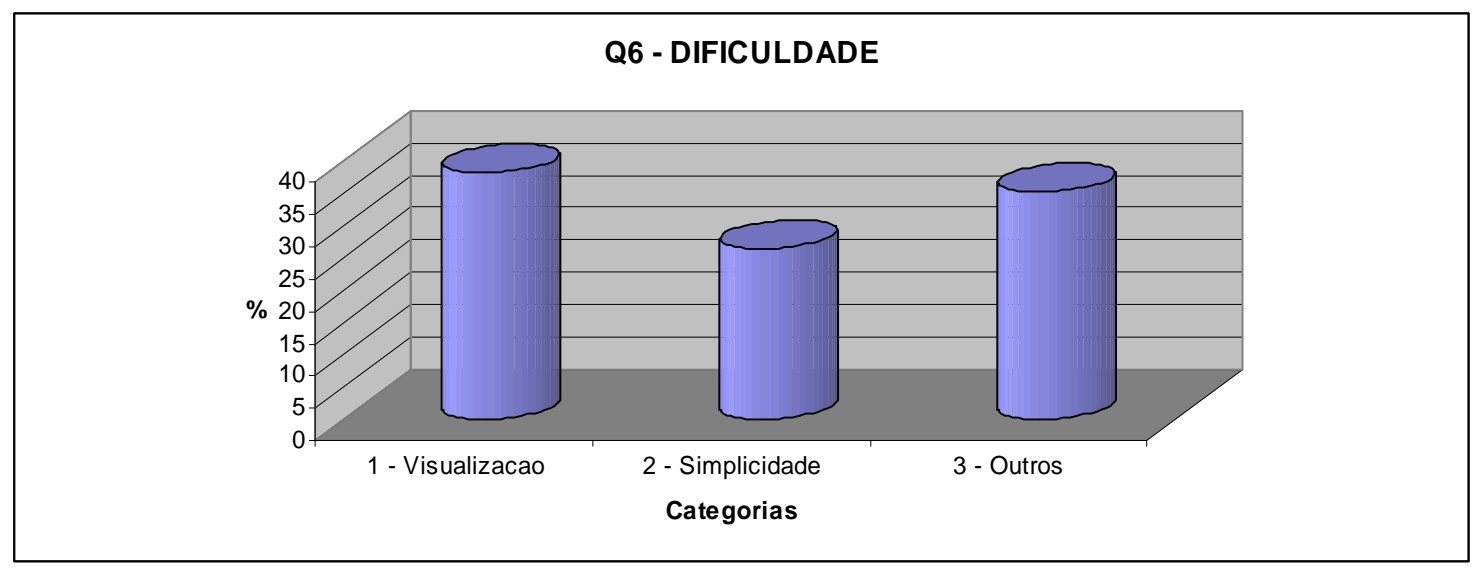

Figura 13. A figura representa o gráfico demonstrativo do resultado da questão 6.

$\mathrm{Na}$ terceira e última categoria agrupamos as respostas em branco ou relacionadas a outros fatores, ou mesmo a fatores que não puderam ser determinados a partir das respostas fornecidas. A Figura 13 representa os 
resultados da questão 5 em um formato gráfico. Do total de respostas, $38.2 \%$ dos estudantes relacionaram a facilidade de uso do programa Construtor com seu formato visual de utilização, enquanto que $26.5 \%$ das respostas relacionaram a facilidade de uso com a simplicidade de operação do programa computacional Construtor. Na categoria 'outros' obtivemos um total de $35,3 \%$ do total de respostas. Colocamos abaixo alguns exemplos de respostas classificadas na categoria 'outros'.

Aluno 17: "O conhecimento sobre o construtor facilita".

Aluno 27: "Todos".

Aluno 32: "Quando a gente não curte uma matéria é difícil você querer aprender".

Se somarmos estes as respostas dadas às duas primeiras categorias, ou seja, relacionando a facilidade de uso com o formato visual ou a simplicidade de uso do programa Construtor, teremos um total de $64.7 \%$ das respostas. Comparando os resultados desta questão com os resultados da questão 5 podemos inferir que a facilidade de uso do construtor se deve principalmente ao formato visual de sua utilização e a simplicidade na operação do programa.

Colocamos abaixo algumas respostas obtidas para esta questão.

Aluno 2: "O Construtor é fácil de ser utilizado porque além de ser visualizado na tela do computador o desenho, podemos aprender melhor a fórmula estrutural". (Categoria visualização).

Aluno 5: "Ao visualizar as ligações, as bolinhas coloridas que representam os átomos, as imagens facilitam o aprendizado". (Categoria simplicidade).

Aluno 14: "Facilidade é muito gostoso de se trabalhar assim a gente aprende a trabalhar a forma". (Categoria simplicidade). 
Aluno 22: "Nenhuma, porque o Construtor parece lego".

O programa Construtor cria uma representação icônica (objeto molecular virtual) a partir de uma representação de qualidade semiótica simbólica (fórmula estrutural condensada). As respostas dos Alunos 5 e 22 indicam que os estudantes, ao utilizarem o programa Construtor, conseguem relacionar uma representação molecular com objetos cotidianos, uma vez que tanto na representação icônica do objeto molecular virtual tridimensional quanto na representação bidimensional da área de animação do Construtor o estudante manipula as representações no formato de "bolinhas e varetas", que são objetos de fácil acesso. Com isso o estudante aprende o que não conhece a partir do que já conhece, o que simplifica o significado de representações onde os estudantes sentem maior dificuldade, ou seja, as representações da dimensão simbólica do conhecimento químico.

\section{Questões 7 e 8}

As questões 7 e 8 serão analisadas conjuntamente porque perguntam a respeito da utilidade, na opinião do estudante da utilização de dois tipos de modelos moleculares no ambiente virtual descrito neste trabalho.

$\mathrm{Na}$ questão 7 pedimos para os estudantes responderem a respeito da utilidade do programa Construtor na compreensão das propriedades dos hidrocarbonetos. Na questão 8 os estudantes responderam a respeito da utilidade dos modelos moleculares concretos na compreensão de propriedade dos hidrocarbonetos. As respostas foram pedidas num formato de escala Likert de cinco pontos. Relacionamos abaixo o enunciado destas questões, bem como os resultados obtidos paras as mesmas.

\section{Enunciado da questão 7}

Especificamente sobre sua capacidade de compreender as propriedades dos hidrocarbonetos, o construtor foi: (1 = inútil; 2 = pouco útil; 3 = indiferente; 4 = útil; 5 = muito útil) 


\section{Enunciado da questão 8}

Especificamente sobre sua capacidade de compreender as propriedades dos hidrocarbonetos, o modelo de estrutura molecular espacial fornecido pelo professor (bolas e bastões plásticos) foi: (1 = inútil; 2 = pouco útil; $3=$ indiferente; 4 = útil; 5 = muito útil)

A Figura 14 e a Tabela 9 demonstram os resultados obtidos para as questões 7 e 8 do questionário. Sobre a utilidade dos modelos concretos e do programa construtor na compreensão das propriedades dos hidrocarbonetos, obtivemos $0 \%$ de respostas na categoria 'inútil'. Na categoria 'pouco útil' obtivemos $8,8 \%$ de repostas sobre o programa Construtor e 5,9\% sobre os modelos concretos. Na categoria 'indiferente' obtivemos em ambas as perguntas $2,9 \%$ das respostas. Somadas estas duas categorias para cada pergunta, sobre a utilidade do programa Construtor temos um total de $11,7 \%$, enquanto que para os modelos concretos temos um percentual de $8,8 \%$. $\mathrm{Na}$ categoria 'útil' obtivemos um total de $58,8 \%$ sobre o uso do Construtor e $32,4 \%$ sobre o uso dos modelos concretos, e na categoria 'muito útil' obtivemos um total de 26,5 sobre a utilidade do Construtor e $58,8 \%$ sobre a utilidade dos modelos concretos na compreensão das propriedades dos hidrocarbonetos.

\begin{tabular}{|c|c|l|}
\hline $\begin{array}{c}\text { Q7 - Utilidade do } \\
\text { Construtor }\end{array}$ & $\begin{array}{c}\text { Q8 - Utilidade dos } \\
\text { modelos } \\
\text { concretos }\end{array}$ & Escala Likert \\
\hline 0 & 0 & 1 - inútil \\
\hline 8,8 & 5,9 & 2 - pouco útil \\
\hline 2,9 & 2,9 & 3 - indiferente \\
\hline 58,8 & 32,4 & 4 - útil \\
\hline 26,5 & 58,8 & 5 - muito útil \\
\hline
\end{tabular}

Tabela 9. A tabela demonstra os resultados das perguntas 7 e 8 do questionário.

Somadas as duas categorias com maior número de respostas, que são as categorias 'útil' e 'muito útil', a utilização do construtor tem um total de $85,3 \%$ de respostas, e os modelos concretos $91,2 \%$ do total de respostas. Em um primeiro momento os resultados mostram que existe preferência dos estudantes pelos modelos concretos (32.4\% útil; 58.8\% muito útil) em relação 
ao uso do Construtor (58.8\% útil; $26.5 \%$ muito útil), para as propriedades estudadas. Isto pode ser devido ao fato de não haver no ambiente uma atividade específica onde as propriedades dinâmicas das moléculas fossem explicitamente utilizadas, sendo necessário a obtenção de mais dados para confirmar ou não tal hipótese.

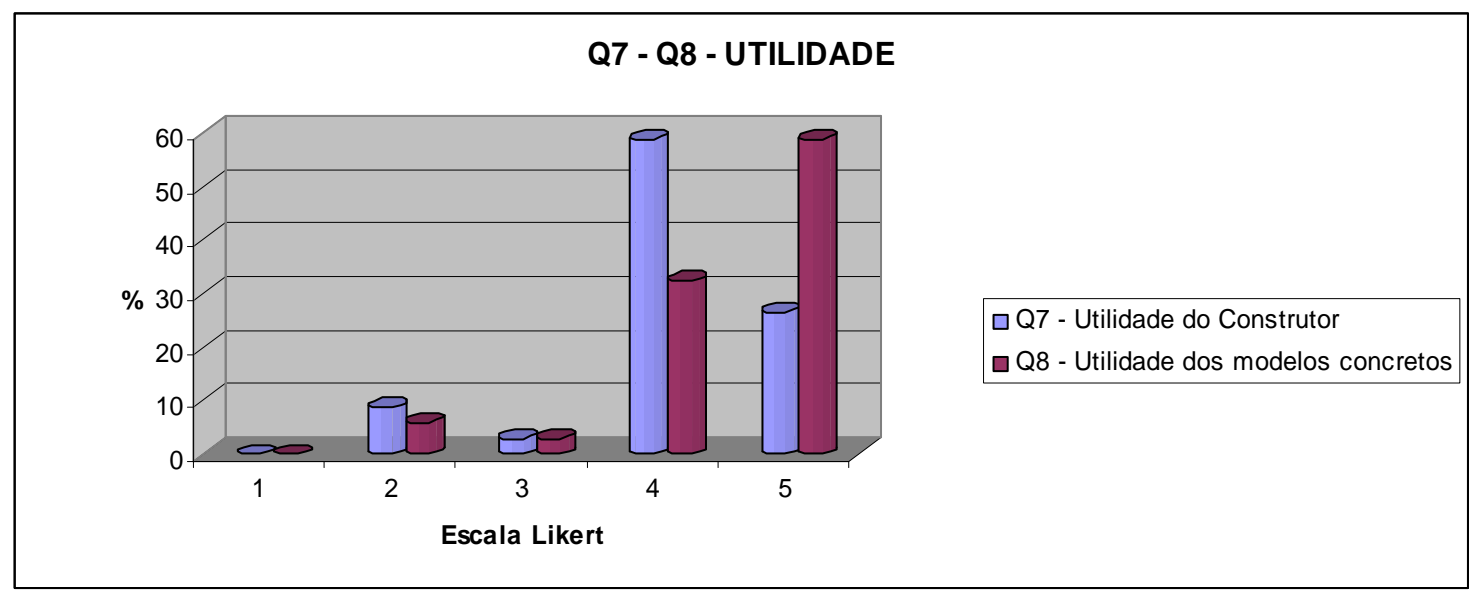

Figura 14. A figura representa o gráfico demonstrativo dos resultados das perguntas 7 e 8 do questionário.

Além disso, as atividades propostas no ambiente virtual não requisitavam a construção de modelos moleculares com mais do que quatro carbonos, o que de fato facilita o uso dos modelos concretos. Outro fator que pode ter contribuído para este resultado é o pouco contato que os estudantes desta turma tiveram com dispositivos computacionais. Apesar de não ter dados que afirmem categoricamente isso, durante a realização das atividades propostas no ambiente, pudemos perceber a dificuldade que boa parte dos estudantes teve com a utilização básica de um computador, como manipulação do mouse, abertura e fechamento de janelas etc. As respostas obtidas na questão 9, discutidas logo abaixo, trazem maior compreensão sobre a preferência comparada dos estudantes. Independentemente da preferência ou não dos estudantes por modelos concretos nas atividades escolhidas para 0 ambiente virtual, a utilização do Construtor de Objetos Moleculares também foi considerada como sendo útil ou muito útil pela maioria $(85,3 \%)$ dos estudantes. 


\section{Questão 9}

Nesta questão solicitamos aos estudantes para responderem os motivos que os levaram a classificar o programa Construtor e os modelos concretos, nas questões 7 e 8, como 'inúteis' ou 'muito úteis'. Nesta questão os estudantes puderam colocar suas respostas de forma aberta.

\section{Enunciado da questão 9}

Comparando suas respostas para os itens 7 e 8 , relacione abaixo os fatores que te levaram a selecionar graus distintos ou idênticos de utilidade.

A Figura 15 representa de forma gráfica os resultados da pergunta 9 do questionário. Separamos as respostas a esta questão em três categorias. Na primeira categoria agrupamos as respostas que relacionaram a utilidade do Construtor ou dos modelos concretos com a praticidade do método ou pelo fato de a montagem de peças ser um trabalho manual. Numa segunda categoria agrupamos as respostas que relacionaram a utilidade com a utilização do computador. Em uma terceira categoria agrupamos respostas em branco e relacionadas a outros fatores, como estudantes que deram como resposta a palavra "legal".

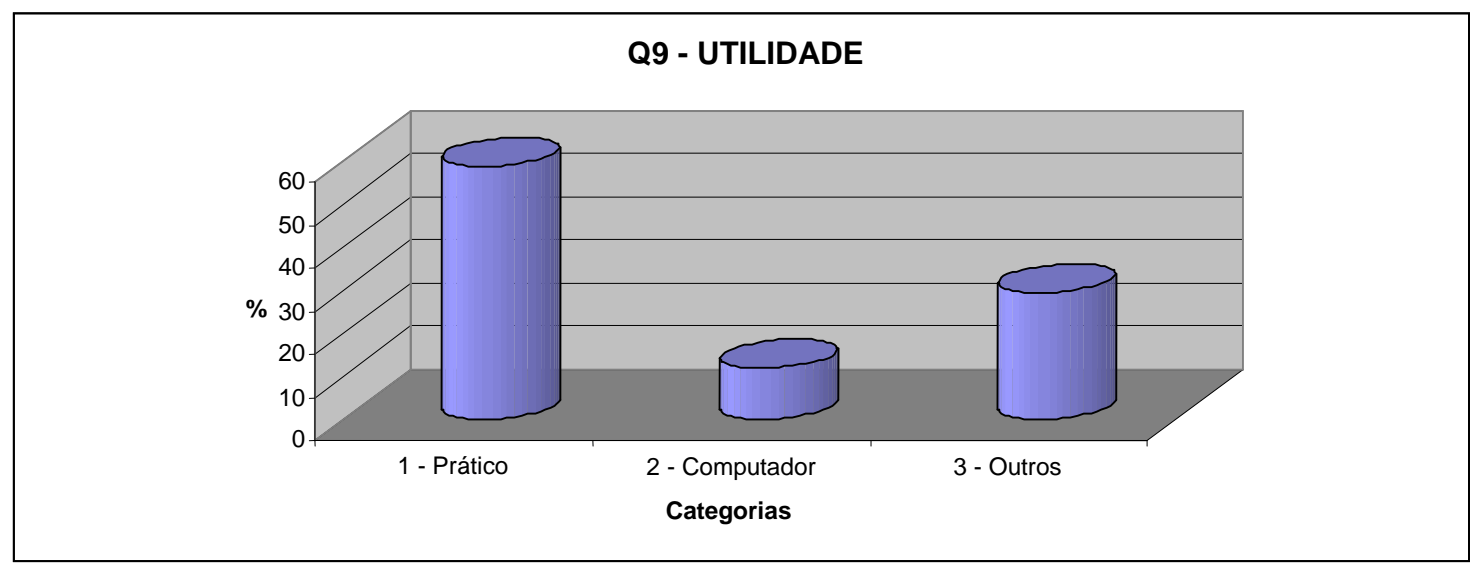

Figura 15. A figura representa o gráfico demonstrativo do resultado da pergunta 9 do questionário.

Do total de respostas, $58.8 \%$ dos estudantes relacionaram a utilidade do construtor e/ou dos objetos moleculares concretos com a praticidade de 
montagem dos modelos. Outros $11.8 \%$ dos estudantes relacionaram a utilidade com o fato de estarem utilizando o computador. Podemos inferir a partir das respostas das questões 7, 8 e 9, que os estudantes acharam útil relacionar a teoria vista em sala de aula e no próprio ambiente virtual com objetos concretos ou virtuais que requeiram atividades de manipulação ou montagem.

Colocamos abaixo algumas respostas obtidas para esta questão.

Aluno 2: "Os dois são ótimos, podemos formar de nossa forma e cores, ajudando a pensar melhor e aprender como forma um hidrocarboneto".

Aluno 6: "O que me levou a ter esta opinião foi o fato da facilidade, como se você aprendesse na prática".

Aluno 11: "Porque não precisa utilizar as bolinhas manualmente, é só construir no computador".

Aluno 18: "Eu acho mais prático montar os modelos do que usar o Construtor (pelo menos na parte da esquerda ${ }^{1}$ ). Exige menos coordenação. Mas poder visualizar o hidrocarboneto digitando a sua fórmula é algo muito útil".

A partir da resposta do Aluno 18 podemos entender que uma parte dos estudantes achou mais útil a manipulação dos modelos concretos do que a parte de animação (parte da esquerda) do Construtor de Objetos Moleculares, ou seja, a parte onde os estudantes, com o auxílio do mouse, montaram modelos bidimensionais através do posicionamento correto de bolinhas e bastões, conforme a Figura 6 no capítulo de metodologia. Provavelmente muitos estudantes sentiram dificuldade na utilização dos dispositivos computacionais, por terem pouco contato com os mesmos, e com isso acharam mais úteis os modelos concretos, o que ajuda a entender melhor os resultados das questões 7 e 8.

Os modelos concretos, os objetos moleculares virtuais tridimensionais e as bolinhas e varetas bidimensionais do ambiente de animação do Construtor são representações com qualidades icônicas da dimensão submicroscópica do

1 Parte de animação do Construtor. 
conhecimento químico. Os resultados das questões 7 e 8 do questionário mostram que os estudantes classificam, em sua quase totalidade, o trabalho com representações de qualidade icônica como "útil" ou "muito útil". A resposta do Aluno 18 mostra que a possibilidade de visualização de objetos moleculares com significação icônica utilizando apenas a fórmula com significação semiótica simbólica é bastante útil para os estudantes.

\section{2 - Entrevista e captura de vídeo}

Após a aplicação do questionário, entrevistamos cada um dos três estudantes que fez parte da dupla-foco, identificados como $F, S$ e J, que haviam utilizado o sistema de captura múltipla e sincronizada de vídeo. Entrevistamos um total de três estudantes, pelo fato de os mesmos terem vindo para a sala de computadores em dois dias distintos, e no segundo dia um dos estudantes (que já havia utilizado o sistema no primeiro dia) não pôde comparecer.

Selecionamos alguns trechos dentre os arquivos de vídeo resultantes do sistema de captura sincronizada acoplado ao ambiente virtual de Ensino de Química. Escolhemos 3 trechos onde percebemos situações em que houve mudança de interesse por parte dos estudantes durante a realização das atividades de ensino propostas no ambiente virtual. Esta mudança de interesse foi percebida, por exemplo, quando foi solicitado aos estudantes o manuseio dos modelos moleculares concretos. Consideramos como mudança de interesse as situações onde que foram percebidas modificações da tonalidade de voz, no posicionamento físico, na expressão facial ou no conjunto destes fatores quando os estudantes realizavam as atividades propostas.

Em seguida, mostramos os trechos de vídeo de forma individual para os próprios estudantes, sendo diferentes trechos de vídeo para cada um dos estudantes, e os entrevistamos individualmente, aplicando o questionário da Tabela 6 no capítulo de metodologia. A nossa intenção, ao mostrarmos os trechos de vídeo referentes à determinada situação de ensino, era tornar mais presente na memória do estudante os detalhes a respeito dos acontecimentos durante a realização das atividades. 
Gravamos o áudio das entrevistas e transcrevemos abaixo alguns trechos que destacam a potencialidade do ambiente para o desenvolvimento de habilidades de representação estrutural química. A transcrição será apresentada em quatro colunas, que apresentam o turno de fala, a identificação do estudante ( $F, S$ ou $J$ ), a fala do mesmo e os gestos, respectivamente. Apresentamos, para cada situação selecionada, a transcrição da captura sincronizada de vídeo, com o objetivo de situar o leitor, e em seguida a transcrição da entrevista, com o objetivo de explicitar as atitudes dos estudantes entrevistados.

\subsection{1 - Sobre o trabalho em dupla utilizando o ambiente virtual}

Descrevemos abaixo um extrato que exemplifica a importância do trabalho em dupla no ambiente virtual descrito neste trabalho.

\section{Captura sincronizada de vídeo.}

Ao chegarem à página $\mathrm{J}$, que é a penúltima da seqüência de ensino proposta (Anexo 1), a estudante $\mathrm{F}$ (18 anos) e o estudante $\mathrm{S}$ (18 anos) se deparam com um exercício que privilegia o trabalho com a representação do tipo fórmula molecular (Figura 16). Ambos lêem a questão individualmente e em silêncio por aproximadamente 50 segundos, mas têm dificuldade em entender o enunciado da questão (Tabela 10).

Em seguida os estudantes começam a discutir sobre cada parágrafo da questão e finalmente conseguem resolvê-la, chamando o professor ao final para confirmar ou não a resolução correta.

\section{Entrevista}

Entrevistamos a estudante $\mathrm{F}$, após a mesma assistir o trecho de vídeo referente à Figura 16 e a Tabela 10, utilizando as perguntas da Tabela 6 do capítulo de materiais e métodos. Sobre este trecho, a estudante respondeu que o seu grau de interesse (questão 2) naquele momento era 5 (total interesse), e que o grau de dificuldade (questão 5) daquela atividade também era 5 (muito fácil). 


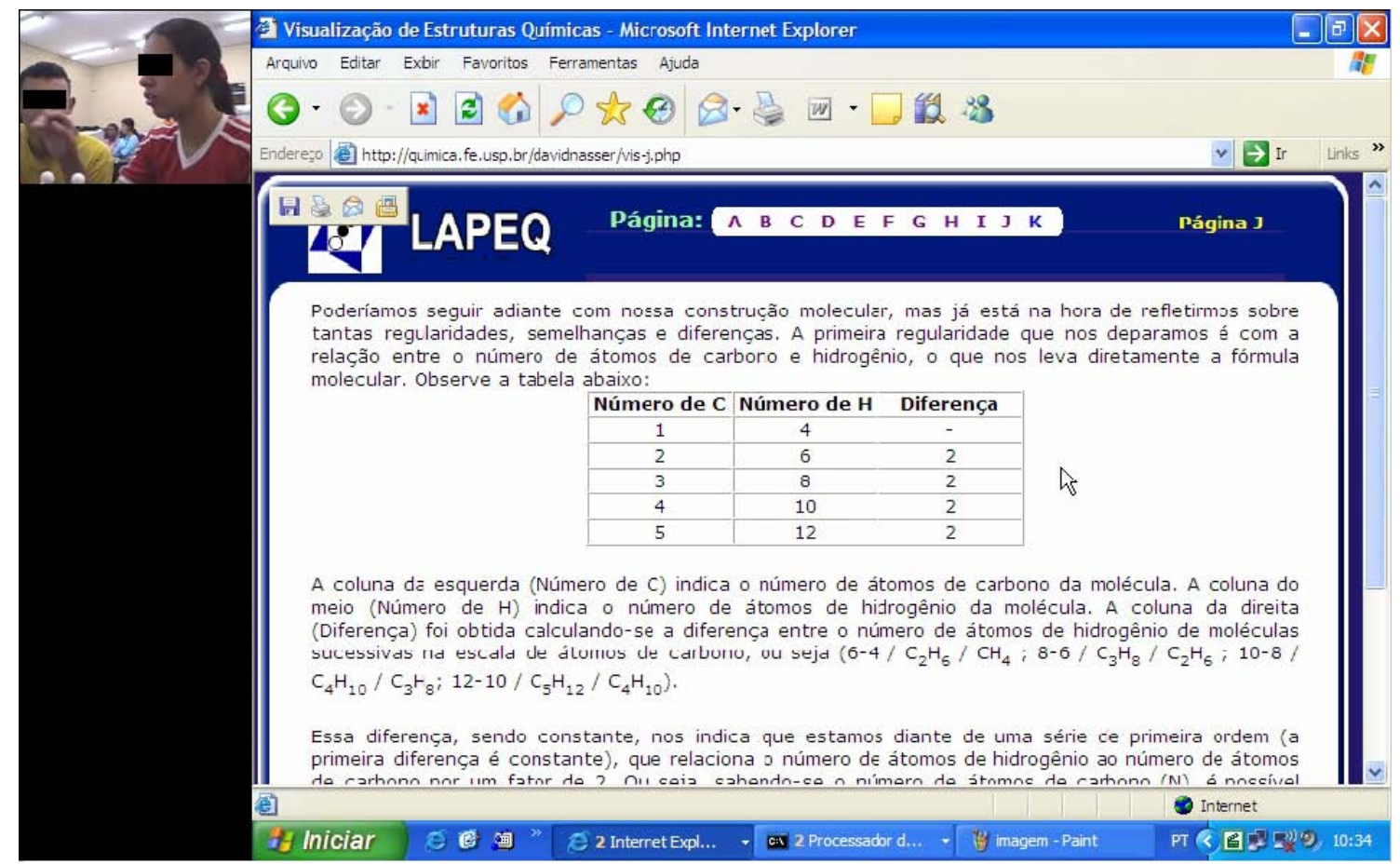

Figura 16. Imagem de arquivos de vídeo no momento em que os estudantes têm dúvida ao resolver um exercício em dupla.

\begin{tabular}{|l|l|l|l|}
\hline 1 & S & Peraí, agora... Agora eu me confundi. & Coçando a cabeça. \\
\hline 2 & F & Aonde? & $\begin{array}{l}\text { Apontando a tela do } \\
\text { computador. }\end{array}$ \\
\hline 3 & S & $\begin{array}{l}\text { Nesse parágrafo todo aqui. É assim, ó: aqui eu } \\
\text { tava até entendendo a lógica, mas aí chegou } \\
\text { aqui e eu me confundi. }\end{array}$ & $\begin{array}{l}\text { Apontando a tela do } \\
\text { computador }\end{array}$ \\
\hline 5 & F & S lê o parágrafo em voz alta). É isso? & $\begin{array}{l}\text { É. } \\
\text { Com o dedo na tela. }\end{array}$ \\
\hline 6 & F & $\begin{array}{l}\text { Tá, peraí. } \\
\text { Tabela 10. Transcrição de áudio sobre o trabalho em dupla no computador. A } \\
\text { transcrição foi feita a partir dos arquivos de vídeo obtidos na captura sincronizada. }\end{array}$ & $\begin{array}{l}\text { Acenando com } \\
\text { cabeça }\end{array}$ \\
\hline
\end{tabular}

Quando perguntamos qual era a sensação da estudante $F$ naquele momento (questão 4), a mesma respondeu que "tinha um interesse muito grande em resolver este exercício". Também perguntamos o motivo da 
mudança de interesse naquele momento (questão 3), e transcrevemos abaixo a resposta da estudante $\mathrm{F}$.

F - "A gente resolve tudo em dupla ali, né? Então a gente já tava interessada, mas na hora que veio a dificuldade, porque às vezes ele fazia uma pergunta que os dois num tinha muita certeza da resposta, e num tinha encontrado a resposta ainda, então, a gente, não, vamo vê, vamo lê, pra vê qual é a resposta. Então o nível de... acho que na hora que precisou mais que a gente pensasse mais um pouco, raciocinasse mais um pouco, ficou mais interessante".

Transcrevemos abaixo a resposta da estudante $F$, quando a mesma foi questionada sobre o que chamou a sua atenção naquele momento (questão 1).

F - "Esse foi o exercício que eu mais gostei, porque mesmo a gente pedindo auxílio pro senhor, a gente conseguiu fazer a resolução dele. A gente tentou ler alto pra entrar num acordo. Porque eu tava lendo baixo, mas tava assim, entendendo, mas tinha parte que eu num entendia. Aí eu falei, então vamo lê alto, aí a gente vê. Porque às vezes lendo alto, pra mim ao menos, o entendimento é melhor. Aí eu resolvi ler alto".

Nas respostas da estudante $F$ às questões 1 e 3 podemos perceber a importância de os estudantes trabalharem em duplas, e não sozinhos, na resolução das atividades de ensino propostas no ambiente virtual. Quando os estudantes trabalham em duplas existe a possibilidade de interlocução entre os pares na resolução de dificuldades conjuntas ou individuais, o que pode auxiliar na organização das suas expressões verbais e do próprio pensamento. Estas razões são plenamente justificáveis por princípios de perspectivas socioculturais, como aquelas defendidas por Vigotski [REGO, 1995] e Bakhtin [1981].

Neste episódio podemos destacar a importância do sistema de captura sincronizada de vídeo no ambiente virtual descrito neste trabalho, uma vez que é possível descrever com mais precisão os detalhes sobre as formas de 
referência conjunta dos estudantes diante do computador ao realizarem as atividades de ensino propostas neste ambiente virtual.

\subsection{2 - Sobre o ambiente privilegiar a visualização de objetos moleculares}

Descrevemos abaixo um extrato que exemplifica a importância da integração de várias formas de representação em um mesmo ambiente.

\section{Captura sincronizada de vídeo.}

Ao chegarem à página $\mathrm{G}, \mathrm{o}$ estudante $\mathrm{S}$ (18 anos) e a estudante $\mathrm{J}$ (17 anos) se deparam com uma nova ferramenta de construção de objetos moleculares que é o Construtor de Objetos Moleculares. Até o momento eles já haviam utilizado os objetos moleculares concretos e haviam comparado estes modelos com as representações bidimensionais. Ao lerem em voz alta a questão que solicita o uso desta ferramenta, ficam vacilantes quanto ao que devem fazer para executar a atividade, uma vez que os estudantes têm diante de si apenas o hyperlink para a ferramenta, e não a própria ferramenta, no momento da leitura da atividade proposta no ambiente virtual.

Quando acionam o hyperlink que abre a janela para a utilização do Construtor de Objetos Moleculares, os estudantes se surpreendem com a mudança repentina no ambiente, conforme descrito no extrato abaixo (Tabela 11), mais especificamente no terceiro turno de fala. O estudante $S$ então se lança a experimentar a ferramenta disponibilizada, seguindo a instrução dada no exercício. Quando o estudante S experimenta o programa Construtor e observa o resultado, que é a abertura de uma nova janela com um objeto molecular virtual e tridimensional, ambos se surpreendem, conforme o décimo turno de fala da Tabela 11 e a Figura 18.

Quando observam o objeto molecular virtual resultado do programa Construtor, S e J ficam eufóricos, conforme mostrado na Figura 18. No terceiro turno de fala (Tabela 11), da estudante $\mathrm{J}$, podemos perceber que atividades de ensino que tenham algum tipo de conexão com o lúdico aumentam o interesse dos estudantes. 


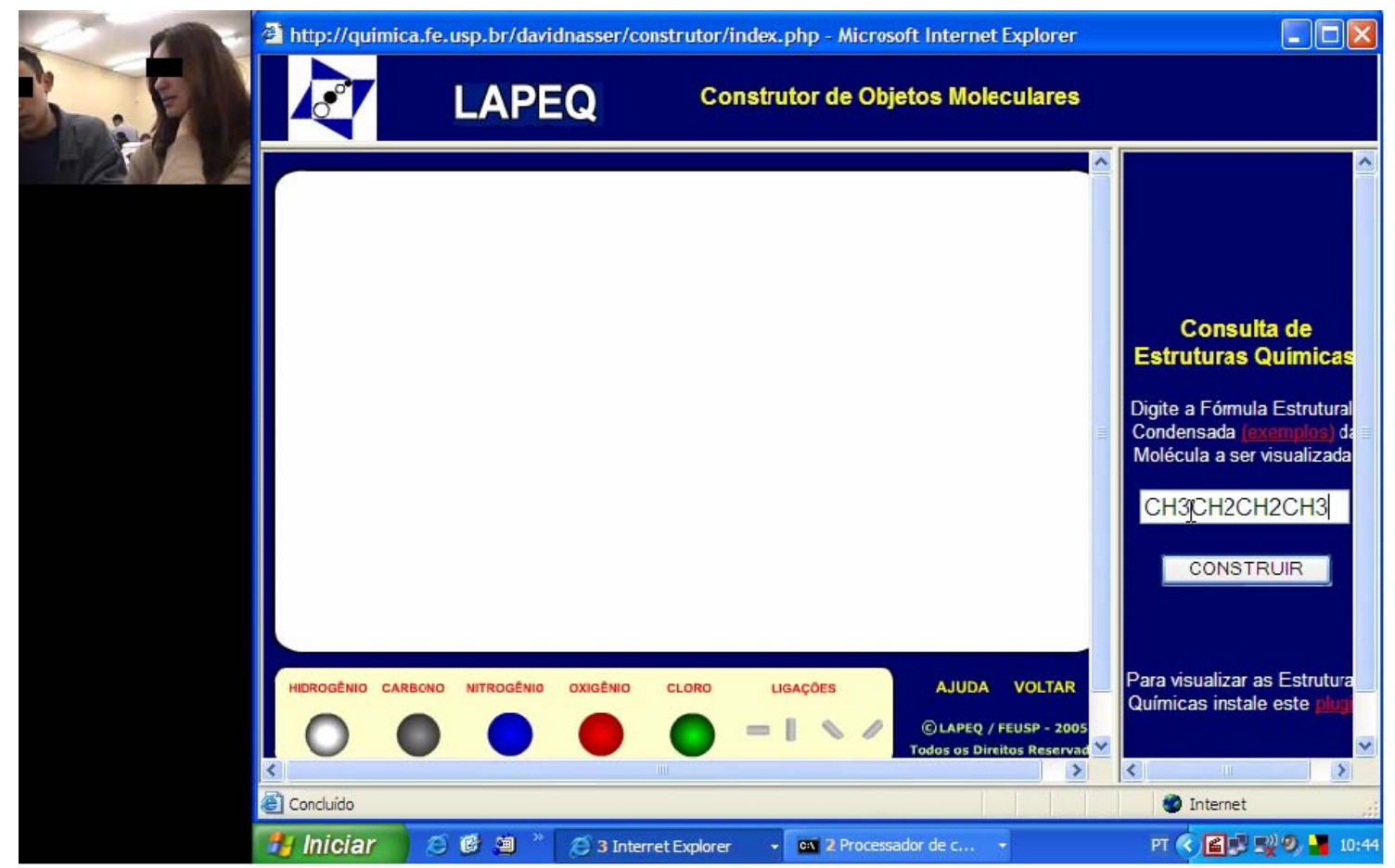

Figura 17. Imagem do arquivo de vídeo obtida no sistema de captura sincronizada no momento em que os estudantes experimentam a ferramenta Construtor.

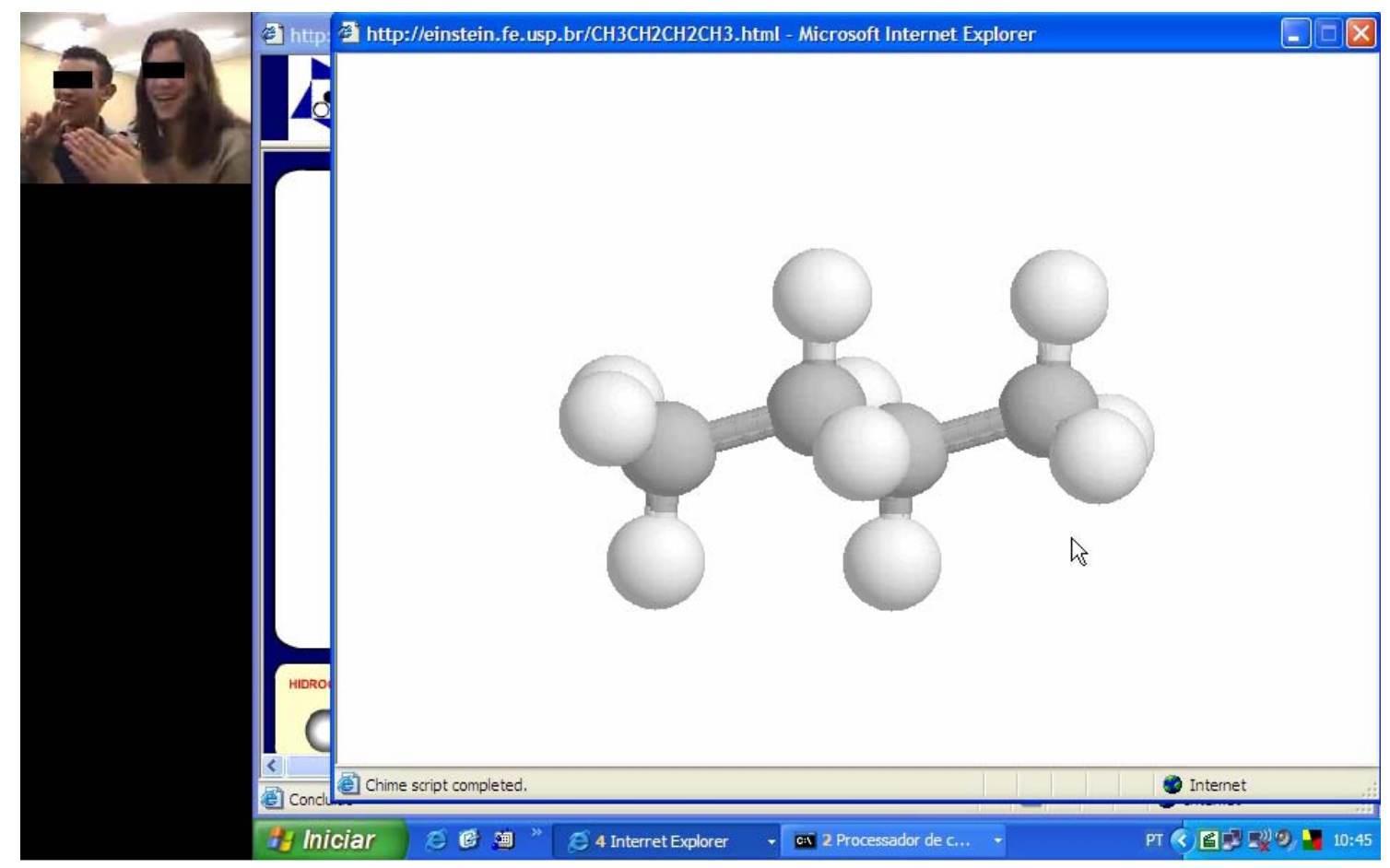

Figura 18. Imagem do arquivo de vídeo obtida no sistema de captura sincronizada no momento em que os estudantes conseguem resolver um exercício. 


\begin{tabular}{|c|c|c|c|}
\hline 1 & $\mathrm{~S}$ & 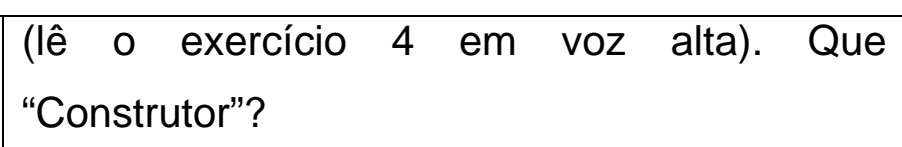 & Coçando a cabeça. \\
\hline 2 & $\mathrm{~s}$ & Construtor & $\begin{array}{l}\text { Clica sobre o hiperlink } \\
\text { que abre o programa. }\end{array}$ \\
\hline 3 & $\mathrm{~J}$ & Nossa! Que máximo! & $\begin{array}{l}\text { Observando a tela do } \\
\text { programa e sorrindo. }\end{array}$ \\
\hline 4 & $\mathrm{~J}$ & Construir. & $\begin{array}{l}\text { Lendo a instrução de } \\
\text { uso do programa. }\end{array}$ \\
\hline 5 & $\mathrm{~J}$ & Qual que é pra gente representar? & \\
\hline 6 & $\mathrm{~S}$ & (lê o exercício 4 em voz alta) & $\begin{array}{l}\text { Lê em voz alta } \\
\text { novamente o exercício } \\
4 .\end{array}$ \\
\hline 7 & $\mathrm{~J}$ & $\begin{array}{l}\text { Qual é? (o propano) O que que a gente vai } \\
\text { fazer? }\end{array}$ & \\
\hline 8 & $\mathrm{~s}$ & $\begin{array}{l}\text { Acho que a gente vai colocar aqui a fórmula e } \\
\text { ele (o Construtor) vai construir. }\end{array}$ & $\begin{array}{l}\text { Clica com o ponteiro } \\
\text { do mouse sobre a } \\
\text { área disponibilizada } \\
\text { pelo programa para } \\
\text { entrada de dados. }\end{array}$ \\
\hline 9 & $\mathrm{~S}$ & O Propano é $\mathrm{CH}_{3} \mathrm{CH}_{3}(\mathrm{SIC})$. & $\begin{array}{l}\text { Digita } \mathrm{CH}_{3} \mathrm{CH}_{3} \text { na área } \\
\text { de entrada de dados e } \\
\text { clica em "Construir". }\end{array}$ \\
\hline 10 & e & (risos) & $\begin{array}{l}\text { Batem palmas ao } \\
\text { verem o objeto } \\
\text { molecular (Fig. 17) }\end{array}$ \\
\hline
\end{tabular}

Tabela 11. Transcrição de áudio sobre a utilização a parte de simulação do programa Construtor. A transcrição foi feita a partir dos arquivos de vídeo obtidos na captura sincronizada.

\section{Entrevista}

Entrevistamos o estudante S, após o mesmo assistir o trecho de vídeo referente às Figuras 17 e 18 e a Tabela 11, utilizando as perguntas da Tabela 6 do capítulo de materiais e métodos. Sobre este trecho, o estudante respondeu 
que o seu grau de interesse (questão 2) naquele momento era 4 (muito interesse), e que o grau de dificuldade (questão 5) daquela atividade também era 4 (fácil).

Também perguntamos para o estudante $\mathrm{S}$, após o mesmo assistir este extrato em formato de vídeo, o motivo da mudança de interesse naquele momento (questão 3). Abaixo transcrevemos a resposta do estudante.

S - "Mas é engraçado, porque eu olho pra essa mesa, eu num consigo imaginar aquele monte de bolinhas (os modelos atômicos concretos) nessa mesa. Essa mesa é feita de um monte dessas bolinhas, dessas moléculas. Você olha, e você num vê átomos nas coisas, mas ai você vê que as coisas... eu sei que as coisas são feitas de átomos, mas eu num vejo os átomos, então aí quando a gente consegue ver é legal, é interessante".

$\mathrm{Na}$ transcrição da entrevista com o estudante $\mathrm{S}$ podemos perceber a importância das visualizações na compreensão de propriedades da matéria. $O$ estudante relata que "quando a gente consegue ver" ocorre mudança do seu interesse, uma vez que as entidades que são trabalhadas cotidianamente com os estudantes, que são os átomos e moléculas, não estão em na escala de percepção direta dos seres humanos. Além disso, as representações que são geralmente mostradas aos estudantes em sala de aula são da dimensão simbólica do conhecimento químico, ou mesmo da dimensão submicroscópica, mas num formato bidimensional e estático, as quais não revelam parte importante do conhecimento químico.

Este relato reforça a importância das representações que tornam evidentes as características dinâmicas da matéria. O uso do programa computacional Construtor faz com que os estudantes tenham acesso a importantes informações da constituição da matéria através da simples percepção direta, utilizando as qualidades icônicas de objetos moleculares virtuais tridimensionais. Neste caso, quando os estudantes enxergaram mais do que letras e números estáticos nas representações químicas o interesse dos mesmos aumentou, de forma que temas relacionados à constituição da matéria podem ser abordados de forma mais prazerosa para os estudantes. 
Para o estudante S, "conseguir ver" é sinônimo de entrar em contato com representações de qualidade icônica da dimensão submicroscópica do conhecimento químico. Este estudante já tinha pleno conhecimento das representações de qualidade semiótica simbólica, tanto que ao ser requisitado, prontamente digitou uma fórmula estrutural condensada na área de entrada de dados do Construtor. Apesar de ter digitado erroneamente a fórmula " $\mathrm{CH}_{3} \mathrm{CH}_{3}$ " para o composto "propano", o estudante já sabia que se tratava de um hidrocarboneto insaturado com pequena quantidade de carbonos, além de saber também a proporção apropriada entre carbonos e hidrogênios. No entanto, apesar de ter conhecimento das representações da dimensão submicroscópica, o estudante ainda não tinha "visto" os átomos ou moléculas nas coisas ao seu redor, o que se tornou possível pelo uso do programa Construtor.

Transcrevemos abaixo a resposta do estudante sobre o que o mesmo sentiu a respeito da atividade no instante da realização da mesma (questão 4). Os dados desta transcrição foram obtidos na mesma entrevista e se referem ao mesmo episódio.

S - "Sensação clássica de que eu consegui fazer alguma coisa, tipo de sucesso. Porque eu digitei a fórmula, e apareceu (a fórmula tridimensional), eu consegui fazer alguma coisa...".

Em sua resposta o estudante relata sua sensação de "sucesso" ao conseguir realizar a atividade proposta. Quando colocados diante de novas situações, e com novas ferramentas, é importante que tenham diante de si ferramentas de operação simples, especialmente estudantes iniciantes em Química, uma vez que ferramentas que necessitam operações complexas tendem a deixar os estudantes com a sensação de fracasso diante da não realização das atividades propostas. Este também é um indicio que o programa computacional Construtor é de fácil operação para estudantes de Ensino Médio, uma vez que o estudante $S$ conseguiu operar o programa logo na primeira tentativa. Nesta entrevista não perguntamos a questão 1 para 0 estudante S. 


\subsection{3 - Sobre o ambiente privilegiar o trabalho manual de montagem de objetos moleculares}

O programa computacional Construtor de Objetos Moleculares desenvolvido para este ambiente virtual possui duas interfaces distintas, conforme descrito no Capítulo 3 deste trabalho. Em um dos ambientes, denominado de 'ambiente de animação' o estudante tem a possibilidade de gerar de forma facilitada figuras geométricas circulares coloridas e bastões. Em seguida o estudante pode posicionar estas esferas e bastões em uma área de trabalho no formato de um objeto molecular bidimensional. Dois, dos três estudantes que participaram das duplas-foco, mostraram mudança de interesse ao se depararem com a utilização desta ferramenta e durante a realização das atividades com a mesma.

Descrevemos abaixo um extrato que exemplifica a importância das atividades manuais com auxílio do computador, proporcionadas aos estudantes no ambiente virtual descrito neste trabalho.

\section{Captura sincronizada de vídeo}

Neste extrato, ao chegarem às atividades propostas na página I, 0 estudante $\mathrm{S}$ e a estudante $\mathrm{F}$ são solicitados a utilizar a parte de construção orientada a objeto (Figura 6) do Construtor para representarem uma molécula do gás butano. Quando os mesmos começam a posicionar as bolas e bastões no formato de uma molécula, a estudante $\mathrm{F}$ discorda do posicionamento dado a um bastão pelo estudante S, que opera o computador neste momento. A Figura 19 representa um momento em que finalmente há concordância quanto ao posicionamento das ligações na molécula.

Transcrevemos abaixo (Tabela 12) um extrato que mostra o momento em que os estudantes negociam o posicionamento dos bastões de forma que possa representar de forma mais apropriada um objeto molecular.

\section{Entrevista}

Entrevistamos a estudante $\mathrm{F}$, após a mesma assistir o trecho de vídeo referente à Figura 18 e a Tabela 12, utilizando as perguntas da Tabela 6 do 
capítulo de materiais e métodos. Sobre este trecho, a estudante respondeu que o seu grau de interesse (questão 2) naquele momento era 5 (total interesse), e que o grau de dificuldade (questão 5) daquela atividade também era 5 (muito fácil).

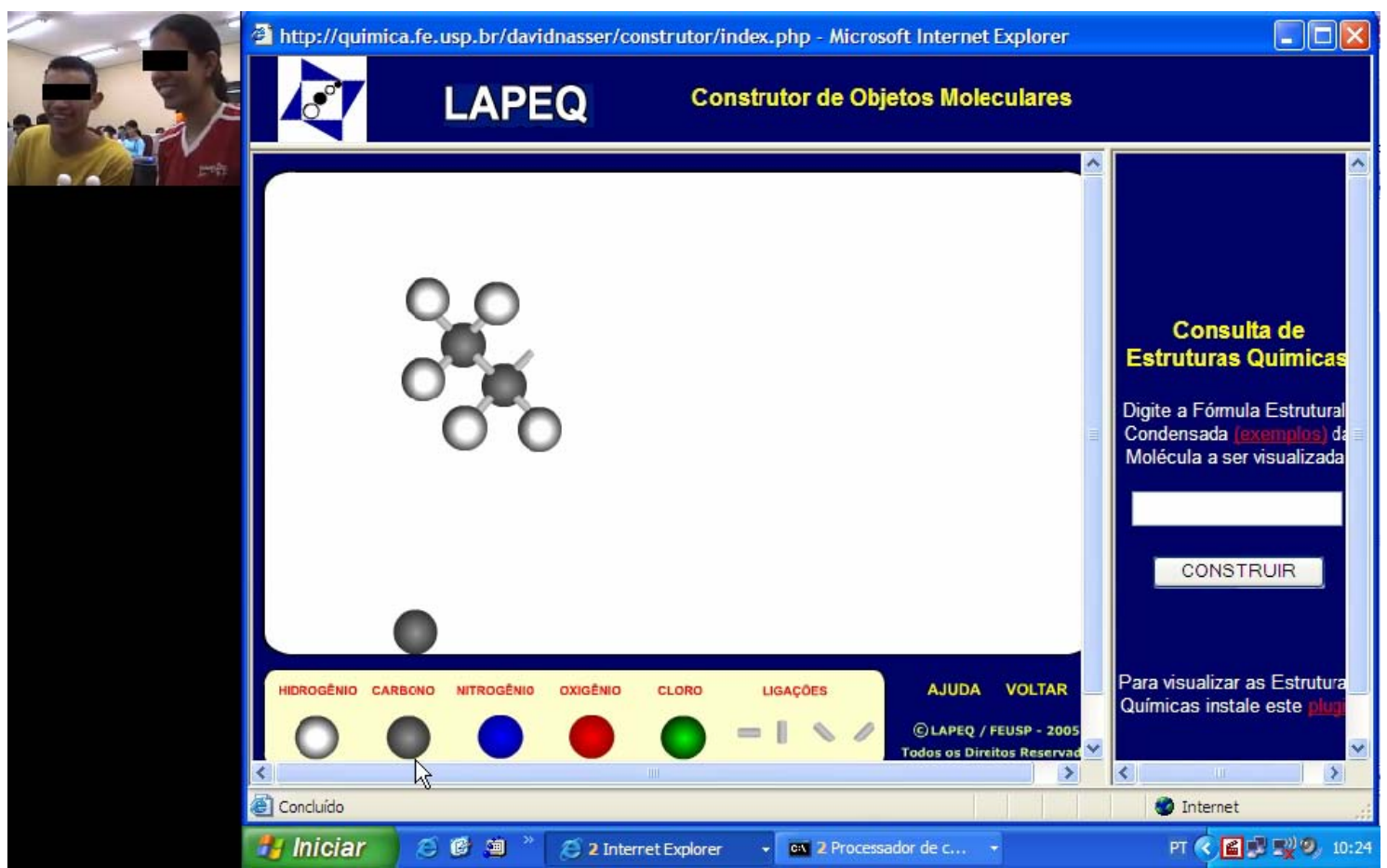

Figura 19. Imagem do arquivo de vídeo sincronizado no momento em que os estudantes realizam atividades manuais de construção de objetos moleculares com o auxílio do programa Construtor.

\begin{tabular}{|l|l|l|l|}
\hline 1 & $\mathrm{~F}$ & $\begin{array}{l}\text { Ihhh... Coloca ele (objeto molecular } \\
\text { simbolizando o átomo) inclinado porque assim } \\
\text { tá muito perto... }\end{array}$ & $\begin{array}{l}\text { Balançando a cabeça } \\
\text { negativamente }\end{array}$ \\
\hline 2 & $\mathrm{~S}$ & $\begin{array}{l}\text { Pérai, deixa eu ver se dá pra dá uma viradinha } \\
\text { (na inclinação do bastão ou ligação química). }\end{array}$ & $\begin{array}{l}\text { Digitando } \\
\text { comandos para girar a } \\
\text { ligação química }\end{array}$ \\
\hline 3 & $\mathrm{~F}$ & Vai, põe pro lado. & Concordando \\
\hline 4 & $\mathrm{~S}$ & Ahhh... Assim tá melhor. & $\begin{array}{l}\text { Tá melhor. } \\
\text { Tabela 12. Transcrição de áudio sobre a utilização a montagem de objetos } \\
\text { moleculares virtuais. A transcrição foi feita a partir dos arquivos de vídeo obtidos na } \\
\text { captura sincronizada. }\end{array}$
\end{tabular}


Perguntamos qual era a sensação da estudante $F$ naquele momento (questão 4), e transcrevemos abaixo a resposta da mesma.

F - "É uma forma legal de se fazer. É bem melhor do que se fazer em sala, porque em sala fica muito... sei lá... muito monótono, e ali não, é basicamente o que eu disse, é mais real a coisa".

Após assistir ao trecho do vídeo, também perguntamos à estudante $\mathrm{F} 0$ que havia chamado sua atenção neste momento da atividade (questão 1). Transcrevemos abaixo a resposta da estudante.

F - "É a forma de montar. Tinha que montar de uma forma que num pudesse ficar muito perto um do outro, porque senão confundiria. Então, as vezes a gente colocava de outro jeito, mas num ficava legal, tinha que colocar de outro, mais inclinado, por que a gente fez um teste, e aí as vezes acabava ..., o hidrogênio acabava ficando um por cima do outro praticamente".

Também perguntamos à estudante $\mathrm{F}$ o motivo da mudança de seu interesse (questão 3), nesta mesma entrevista, e transcrevemos abaixo a resposta.

F - "É justamente por ser... é mais real, entendeu? É como se você pudesse tá vendo e mexendo no carbono e no hidrogênio, realmente".

A partir dos dados da entrevista com a estudante $\mathrm{F}$ podemos perceber a importância da manipulação de objetos, tanto reais quanto virtuais, no aprendizado significativo de conhecimentos importantes na compreensão de propriedades químicas. Quando os estudantes percebem a importância do distanciamento correto entre os átomos e ligações químicas, conforme os turnos de fala 1 e 2 da Tabela 12, e as transcrições das entrevistas, os mesmos estão dando um importante passo na compreensão de propriedades como ângulos e distâncias de ligação. 
A manipulação dos objetos moleculares virtuais do Construtor possibilitou à estudante $F$ uma familiarização com as representações químicas, em especial os aspectos de distanciamento apropriado entre os átomos, de forma que a estudante em pouco tempo já podia dizer se o distanciamento estava apropriado ou não. O contato dos estudantes com representações químicas de qualidades semióticas icônicas faz com que a mediação dos significados possibilitada pelos objetos moleculares veiculados pelo programa computacional Construtor ocorra de forma facilitada. Em aulas de química onde se utiliza apenas giz e quadro negro, os estudantes sentem dificuldade em visualizar o distanciamento apropriado entre os átomos quando se utiliza apenas representações da dimensão simbólica, e este é o caso da maioria das salas de aula de química no Brasil.

Podemos perceber indícios de realismo na fala da estudante $F$ nas respostas às questões 3 e 4 . Isto pode levar a erros conceituais graves por parte do estudante, como no caso de o mesmo relacionar as cores dos objetos moleculares virtuais ou concretos com os próprios átomos. É importante que estes significados sejam negociados entre os estudantes e o professor, de forma que o papel do professor na condução das atividades de ensino é essencial.

De uma forma geral, tanto nos questionários respondidos (Figuras $10 \mathrm{e}$ 12, e Tabelas 7 e 8), quanto nas entrevistas das duplas-foco, em especial nas questões 2 e 5, obtivemos como resultado um baixo grau de dificuldade e um alto grau de interesse, de acordo com os estudantes. Com estes resultados podemos inferir que a facilidade no uso das ferramentas deste ambiente virtual está relacionada com o grau de interesse demonstrado pelos estudantes.

\subsection{4 - Usabilidade em situações de ensino}

Conforme descrevemos neste capitulo, o ambiente virtual descrito neste trabalho foi avaliado por estudantes de ensino médio de uma escola pública do Estado de São Paulo. Para avaliarmos a usabilidade do ambiente virtual e do programa Construtor, desenvolvemos também um sistema de registro de uso de ambientes virtuais, através da captura sincronizada de vídeo. Também solicitamos que os estudantes respondessem a um questionário a respeito da 
utilização do ambiente virtual e do programa Construtor, após realizarem as atividades propostas. Por fim, entrevistamos duas duplas-foco a respeito do interesse dos mesmos em determinadas situações de uso do programa Construtor.

A utilização de um sistema de captura sincronizada de vídeo, em conjunto com questionários e entrevistas forneceram dados para uma análise da usabilidade de ambientes virtuais de ensino e suas ferramentas, e se constitui em uma metodologia de avaliação deste tipo de sistema de ensino. 


\section{5 - CONSIDERAÇÕES FINAIS}

No primeiro capítulo desta dissertação estabelecemos como objetivos de pesquisa a descrição das etapas de desenvolvimento do aplicativo computacional Construtor, e a descrição da avaliação do uso do ambiente virtual descrito neste trabalho.

Neste trabalho, também fizemos uma discussão sobre a contribuição da teoria semiótica de Charles Sanders Peirce, com o objetivo de trazer uma compreensão mais aprofundada a respeito dos processos de significação de representações químicas, dos níveis macroscópico, submicroscópico e simbólico, na sala de aula.

A descrição das etapas de desenvolvimento do programa Construtor foi feita no Capítulo 3 desta dissertação. No desenvolvimento deste programa, privilegiamos a relação entre dois tipos de representação que compõe o conhecimento químico: a dimensão simbólica e a dimensão submicroscópica. $\mathrm{Na}$ dimensão simbólica a representação escolhida foi a fórmula estrutural condensada, e na dimensão submicroscópica a representação escolhida foi um objeto molecular virtual tridimensional, representando um fórmula estrutural tridimensional.

Antes do desenvolvimento e ampla diponibilização dos computadores não era possível a representação de propriedades dinâmicas da matéria em nível atômico. Diante das atuais possibilidades computacionais e de comunicação pela internet, este programa computacional foi desenvolvido para que estudantes de Ensino Médio tenham acesso a ferramentas de simulação por mecânica e dinâmica molecular de forma simplificada, de maneira que as características superficiais de sistemas moleculares veiculadas através deste tipo de ferramenta computacional estejam prontamente disponíveis para estudantes iniciantes em química.

Através do uso do programa Construtor estudantes de Ensino Médio podem obter objetos moleculares virtuais tridimensionais de forma simplificada, digitando a fórmula estrutural condensada de determinado composto. Desta forma os estudantes podem construir representações de qualidade semiótica 
icônica a partir de representações de qualidade semiótica simbólica. As representações de qualidade icônica medeiam seus significados a partir de semelhanças, no nosso caso, semelhanças estas com objetos do cotidiano dos estudantes, no caso bolas e varetas.

A principal característica do programa Construtor para o Ensino de Química é a mediação do significado de estruturas moleculares, de forma a relacionar representações que utilizam apenas letras e números com objetos moleculares virtuais tridimensionais.

O ambiente virtual descrito neste trabalho foi desenvolvido em linguagem HTML e pode ser acessado pela internet com o uso de navegadores hipertexto comuns. O ambiente desenvolvido alia o potencial exploratório do hipertexto com as propriedades de construção e manipulação bidimensional e tridimensional de objetos moleculares do programa Construtor em atividades de ensino que combinam os aspectos semióticos icônicos do conhecimento químico e dinâmicos de propriedades da matéria, para que o estudante tenha a oportunidade de elaborar significados mais próximos ao do atual paradigma da natureza particulada da matéria. Julgamos que estas características beneficiam tanto a disseminação do acesso quanto o aprimoramento das práticas educacionais da sala de aula do Ensino Médio.

A avaliação do uso do ambiente virtual descrito foi descrita no Capítulo 4 desta dissertação. Para esta avaliação desenvolvemos um sistema de captura sincronizada de vídeo, onde são gravados de forma simultânea e sincrônica os vídeos relativos à tela em uso pelo estudante juntamente com as ações do próprio estudante diante do computador na situação de ensino. Junto com este sistema de captura sincronizada de vídeo, os estudantes responderam um questionário sobre a usabilidade do ambiente virtual e do programa Construtor. Por fim realizamos entrevistas com duas duplas-foco. Por meio destes instrumentos de análise constatamos que tanto o ambiente virtual quanto a ferramenta computacional Construtor são de fácil operação, de acordo com os estudantes que realizaram a avaliação. Observamos, portanto, a viabilização desta metodologia de investigação que combina técnicas modernas de aquisição de dados com técnicas eficientes de análise da usabilidade. 
Além disso, propomos que a composição das três ferramentas utilizadas para analisar este ambiente virtual de ensino, ou seja, os vídeos da captura sincronizada, o questionário e as entrevistas, constituam uma metodologia de análise, através da qual ambientes virtuais de ensino possam ser avaliados.

Quando desenvolvi este ambiente virtual e o programa Construtor, tinha em mente criar uma ferramenta que facilitasse o acesso de estudantes de Ensino Médio às atuais ferramentas de criação e visualização de objetos moleculares. Mais do que isso, quando trouxe meus estudantes para a realização das atividades de ensino propostas no ambiente de ensino, senti a satisfação dos mesmos ao compreenderem de forma mais aprofundada o significado das representações químicas. Um dos estudantes da primeira turma, ao terminar o Ensino Médio, prestou vestibular e agora é estudante do curso superior de Química em uma importante instituição de ensino. Me sinto privilegiado ao descobrir que as ações docentes podem mediar o significado não apenas de estruturas químicas, mas também da escolha profissional dos estudantes. 
AgAPOVA, O., JONES, L., USHAKOV, A., RATClifFE, A., MARTIN, M. (2002). Encouraging independent chemistry learning through multimedia design experiences. Chemical Education International, 3(3), 1-8.

ANDREESSEN, M. (1993). NCSA Mosaic Technical Summary; National Center for Supercomputing Applications; February 20.

ANJOS, E. I. (2004). Modelos mentais e visualização molecular: uma estratégia para ensinar química orgânica. Dissertação de mestrado. Universidade de São Paulo, 130 pp.

APPLE, M. W. (1986). O Computador na Educação: parte da solução ou parte do problema? Educação e Sociedade, 23.

ARDAC, D., AKAYGUN, S. (2004). Effectiveness of multimedia-based instruction that emphasizes molecular representations on students' understanding of chemical change. Journal of Research in Science Teaching, 40 (4), 317-337.

ARDAC, D., AKAYGUN, S. (2005). Using static and dynamic visuals to represent chemical change at molecular level. International Journal of Science Teaching, 27 (11), 1269-1298.

AUKSTAKALNIS, S., BLATNER, D. (1992). Silicon Mirage: The Art and Science of Virtual Reality. Peach Pit Press.

BAKHTIN, M. M. The dialogic imagination: four essays. Austin: University of Texas Press, 1981.

BALABAN, A.T. (1999). Visual chemistry: tree-dimensional perception of chemical structures. Journal of Science Educational Technology, 8(4), 251-255.

BARBOZA, L. C., GIORDAN, M. (2007). Perfil de acesso dos alunos em uma disciplina a distância. In: $30^{\text {a }}$ Reunião Anual da Sociedade Brasileira de Química, Águas de Lindóia - SP.

BARNEA, N., Dori, Y. J. (1999). High School chemistry students' performance and gender differences in a computerized molecular modeling learning environment. Journal of Science Education and Technology, 8(4), 257-271. 
BARNEA, N., Dori, Y. J. (1996). Computerized molecular modeling as a tool to improve chemistry teaching. Journal of Chemical Information and Computer Sciences, 36, 629-636.

BARRON, A. (1998). Designing web-based training. British Journal of Educational Technology, 29 (4), 355-370.

BECKWITH, E.K., NELSON, C. (1998). The ChemViz project: using a supercomputer to illustrate abstract concepts in chemistry. Learning and Leading with Technology, 25 (6), 17-19.

BEJARANO, N.R.R., CARVALHO, A.M.P. (2000), A educação química no Brasil: uma visão através das pesquisas e publicações da área. Educación Química, 11 (1) , 160-167, México.

BENENSON, G. (2001). The unrealized potential of everyday technology as a context for learning. Journal of Research in Science Teaching, 38 (7), 730-745.

BEN-ZVI, R., Eylon, B., \& Silberstein, J. (1988). Theories, principles and laws. Education in Chemistry, May, 89-92.

BERGER, C.F., LU, C.R., BELZER, S.J., VOSS, B.E. (1994). Research on the uses of technology in science education. In Gabel, D. (Ed.), Handbook of research on science teaching and learning, MacMillan Publishing Company, New York, pp. 466-490.

BERNERS-LEE, T., CAILLIAU, R., J.F. GROFF, J. F., POLLERMANN, B. (1992). World-Wide Web: The Information Universe. Electronic Networking: Research, Applications and Policy.

BEZZI, A. (1991). A Macintosh program for improving three dimensional thinking. Journal of Geological Education, 39: 284-288.

BOWEN, C.W. (1998). Item design considerations for computer-based testing of student Learning in chemistry. Journal of Chemical Education. 75, 11721175.

BRITO, S.L. (2001). Um ambiente multimediatizado para a construcao do conhecimento quimico. Química nova na escola, 14 (nov), 13-15.

BROOKS, H.B., BROOKS, D.W. (1996). The emerging role of cd-roms in teaching chemistry. Journal of Science Education and Technology, 5 (3), 203215. 
BURKE, K.A., GREENBOWEE, T.J., WINDSCHITL, M.A. (1998). Developing and using conceptual computer animations for chemistry instruction. Journal of Chemical Education, 75, 1658-1661.

CLARK, J. M., PAIVIO, A. (1991). Dual coding theory and education. Educational Psychology Review, 3, 149-210.

COLEMAN, E.B., PENUEL, W.R. (2000). Web-based student assessment for program evaluation. Journal of Science Education and Technology, 9 (4), 327342.

COLLIS, B. (1999). Designing for differences: cultural issues in the design of www-based course-support sites. British Journal of Educational Technology, 30 (3), 201-215.

COPOLO, C.F., HOUNSHELL, P.B. (1995). Using three-dimensional models to teach molecular structures in high school chemistry. Journal of Science Educacion and Technology, 4(4), 295-305.

DE VOS, W., BERKEL, B., VERDONK, A.H. (1994). A coherent conceptual structure of the chemistry curriculum, Journal of Chemical Education, 71, 743746.

DORÉ, S., BASQUE, J. (1998). Le concept d'environmentd'apprentissage. Revue de L'Education à Distance, 13, 40-56.

DORI, Y.J., GABEL, D., BARNEA, N., HAMIERI. M. (1996). Using novel Technologies to enhance chemistry understanding at the phenomena, molecular and symbolic levels. Proceeding of the Second Jerusalem International Science and Technology Education Conference, Jerusalem, Israel, S2-40a.

DORLAND, L. (2002). News from online: what's new with Chime? Journal of Chemical Education, 79, 778-782.

EALY, J.B. (1999). A student evaluation of molecular modeling in first year college chemistry. Journal of Science Education and Technology, 8(4), 309321.

EGE, S.N. (1994). Organic chemistry. Structure and reactivity. 3d Ed., D. C. Health and Company, Lexington, Kentucky.

EICHLER, M.; DEL PINO, J. C. (2000). Carbópolis, um software para educação química, Química Nova, 23, 835. 
ELLIS, T.J., HAFNER, W. (2003). Engineering an online course: applying the secrets of computer programming to course development. British Journal of Educational Technology, 34 (5), 639-650.

FISHER, B.W. (1997). Computer modeling for thinking about and controlling variable, School Science Review, 79, 87-90.

FRANCISCO, C.A. (2006). A produção do conhecimento sobre o ensino de química no Brasil: um olhar a partir das reuniões anuais da Sociedade Brasileira de Química. Dissertação de Mestrado. Universidade de São Paulo.

FRANCO, M.A., CORDEIRO, L.M., CASTILHO, R.A.F. (2003). O ambiente virtual de aprendizagem e sua incorporação na Unicamp. Educação e Pesquisa, 29 (2), 341-353.

FLETCHER, R., (1980). Practical Methods of Optimization, Wiley Interscience, New York, 56-110.

FRENKEL, D., SMITH, B., (1990). Understanding Molecular Simulations: from algorithms to applications, Academic Press, San Diego, 9-15.

GABEL, D.L. (1998). The complexity of chemistry and implications for teaching. In Fraser, B.J., and Tobin, K.G. (Eds.), International Handbook of Science Education, Kluwer Academic Publishers, London, pp. 233-248.

GABEL, D.L., BUNCE, D. M. (1994) Research on problem solving: chemistry. In Gabel, D. L. (Ed.), Handbook of research on Science Teaching and Learning, Macmillan, New Yok, pp. 301-326.

GABEL, D.L., BRINER, D., HAINES, D. (1992). Modeling with magnets - A unified approach to chemistry problem solving. The Science Teacher March, 58-63.

GABEL, D., SHERWOOD, R. (1980). The effect of student manipulation of molecular models on chemistry achievement according to Piagetian level. Journal of Science Teaching, 17(1), 75-81.

GALL, J.E. (2002). Rethinking the computer in education. Journal of Educational Technology Systems, 30 (4), 379, 388.

GARNET, P.J., GARNET. P.J., and HACKING, M. W. (1995). Students' alternative conceptions in chemistry: A review of research and implications for teaching and learning. Studies in Science Education, 25: 69-95. 
GIORDAN, M. (1999). O papel da experimentação no ensino de ciências. Química Nova na Escola, 10, 43-49.

GIORDAN, M. (2005). O computador na educação em ciências: breve revisao crítica acerca de algumas formas de utilização. Ciência e educação, 11 (2), 279-304.

GIORDAN, M., GOIS, J., (2005). Telemática educacional e ensino de química: Considerações sobre um construtor de objetos moleculares. Linhas críticas, 21 (11), 285-302.

GIORDAN, M. (2006). Tese de Livre Docência, Faculdade de Educação - USP. GIORDAN, M., GOIS, J., (2006). Sistema dinâmico de registro da situação de ensino com uso do computador. IV Semana da Educação - FEUSP - Ensinar e Aprender.

GOIS, J. (2004). Desenvolvimento e automatização de um método teórico para a avaliação quantitativa da seletividade de proteínas do MHC por diferentes antígenos. Dissertação de mestrado. Universidade de São Paulo.

GRANT, G.H., RICHARDS, W.G. (1995). Computational Chemistry, Oxford University Press, Oxford, 32-46.

GRAZIADEI, W.D., McCOMBS, G.M. (1995). The 21th century classroomscholarship environment: what will it be like? Journal of Educational Technology Systems, 24(2), 97-112.

GRIFFTHS, A.K., PRESTON, K.R. (1992). Grade-12 students' misconceptions relating to fundamental characteristics at atoms and molecules. Journal of Research in Science Teaching, 29(6), 611-628.

HABRAKEN, C.L. (1996). Perceptions of chemistry: Why is the common perception of chemistry, the most visual of sciences, so distorted? Journal of Science Education and Technology, 5(3), 193-201.

HABRAKEN, C.L. (2004). Integrating into chemistry teaching today's students's visuospatial talent and skills, and the teaching of today's chemistry's graphical language. Journal of Science Education and Technology, 13 (1), 8994.

HAMMOND, G.S. (1977). Teaching chemistry for tomorrow's citizens. International Conference on Chemical Education, Ljubljana, Yugoslavia. 
HEGARTHY, M., CARPENTER, H.A., JUST, M.A. (1991). Diagrams in the comprehension of scientific texts. In R. Barr, M.L. Kamil e P.D. Pearson (Eds.) Handbook of reading research (vol II) pp. 641-668). Nova York: Longman.

HOFFMAN, R., LASZLO, P. (1991). Representation in chemistry. Angewandte Chemie, 30, 1-16.

HSU, Y. (2006). Lesson rainbow: the use of multiple representations in an internet-based, discipline-integrated science lesson. British Journal of Educational Technology, 37 (4), 539-557.

ISDALE, J. (1993). What is Virtual Reality: A Homebrew Introduction. ftp://sunsite.unc.edu/pub/academic/computer-science/virtual-

reality/papers/whatisvr.txt. Acessado em 16/10/2007.

JACKSON, M.D. (1998). A distance-education chemistry course for nonmajors. Journal of Science Education and Technology, 7 (2), 163-170.

JOHNSTONE, A.H. (1993). The Development of chemistry teaching: A changing response to changing demand. Journal of Chemical Education. 70, 701-704.

JOHNSTONE, A.H., LETTON, K.M. (1990). Investigating undergraduate lab work. Education in Chemistry, 28, 81-83.

JOHNSTONE, A.H. (1991). Why is science difficult to learn? Things are seldom what they seem. Journal of Computerized Assisted Learning 7:75-83.

KAISER, M.K., PROFFITT, D.R., WHELAN, S.M., HECHT, H. (1992). Influence of animation on dynamical judgments. Journal of Experimental Psycology: Human perception and performance, 18, 669-689.

KEIG, P.F. e RUBBA, P.A. (1993). Translation of representations of the structure of matter and its relationship to reasoning, gender, spatial reasoning, and specific prior knowledge. Journal of Research in Science Teaching, 30(8), 883-903.

KERNIGHAN, B., RITCHIE, D. (1988). The C programming language, Prentice Hall, New Jersey.

KIMMEL, H., DEEK, F. (1996). Instructional technology: a tool or a panacea? Journal of Science Education and Technology, 5 (1), 87-92. 
KINZIE, M.B., LARSEN, V.A., BURCH, J.B., BOKER, S.M. (1996). Frog dissection via the world-wide web: implications for widespred delivery of instruction. Educational Technology Research and Developent, 44 (2), 59-69.

KIRKPATRICK, S., GELATT, C.D., VECCHI, (1983). Searching for backbones: a high-performance parallel algorithm for solving combinatorial optimization problems, Science, 220: 671.

KISER, L. (1990). Interaction of spatial visualization with computer enhanced and traditional presentations of linear absolute value inequalities. Journal of Computers in Mathematics and Science Teaching 10, 85-96.

KLEIN, U. (2001). Tools and models of representation in the laboratory sciences. Kluwer Academic Publishers, Dordrecht, Holanda.

KORKMAZ, A., HARWOOD, W.S. (2004). Web-supported chemistry education: design of an online tutorial for learning molecular symmetry. Journal of Science Education and Technology, 13 (2), 243-253.

KOZMA, R.B. (1991). Learning with media. Review of Educational Research, $61,179-211$.

KOZMA, R.B., RUSSEL, J. (1997). Multimedia and understanding: Expert and novice responses to different representations of chemical phenomena. Journal of Research in Science Teaching, 34, 949-968.

KOZMA, R.B., CHIN, E., RUSSEL, J., MARX, N. (2000). The roles of presentations and tools in the chemistry laboratory and their implications for chemistry instruction. Journal of the Learning Sciences, 9(2), 105-143.

KOZMA, R.B., RUSSEL, J., JONES, T., MARX, N., DAVIS, J. (1996). The use of multiple, linked representations to facilitate science understanding. In R.G.S. Vosniadou, E. DeCorte, \& H. Mandel (Eds.), International perspective on the psychological foundations of technology-based learning environments (pp. 4160). Hillsdale, NJ: Erlbaum.

KRAJCIK, J.S. (1991). Developing students' understanding of chemical concepts. In S.M.Glynn, R.H. Yeany, \& B.K. Britton (Eds.), The psychology of learning science: International perspective on the psychological foundations of technology-based learning environments (pp. 117-145). Hillsdale, NJ: Erlbaum.

LARKIN, J. e SIMON, H.A. (1987). Why a diagram is (sometimes) worth ten thousand words. Cognitive Sciences, 11, 65-100. 
LÉVY, P. (1998). A ideografia dinâmica. São Paulo: Edições Loyola.

LEMKE, J. (2001). Articulating comunities: sociocultural perspectives on science education, Journal of Research in Science Teaching, 38 (3), 296-316.

LOWE, J.N. (1968). Who will our teachers be? Journal of Chemical Education, 45: 649-650.

MAYER, R. (ed.) (2005). The Cambridge Handbook of Multimedia Learning. Cambridge Press, Cambridge.

MÉHEAUT, M., (1997). Designing a learning sequence about a pre-quantitative kinetic model of gases: the parts played by questions and by the computer simulation. International Journal of Science Education, 19 (6), 647-660.

NADLER, L., NADLER, Z. (1994). Designing training programs: the critical events model. $2^{\text {nd }}$ edition. Houston, TX: Gulf Publishing Company.

NICK, S., ANDRESEN, J., LUBKER, B., THUMM, L. (2003). CHEMnet structure, design and evaluation of an online chemistry course. Journal of Science Education and Technology, 12 (3), 333-341.

NOH, T., SCHARMANN, L.C. (1997). Instructional influence of a molecular-level pictorial preservation of matter on students' conceptions and problem-solving ability, Journal of research in Science Teaching, 34(2), 199-217.

NÖTH, W. (2005). Panorama da semiótica: de Platão a Peirce. São Paulo: Ed. Annablume (4 ${ }^{\mathrm{a}}$ ed).

NYE, M.J. (1993). From chemical philosophy to theoretical chemistry. Berkeley, CA: University of California Press.

OLIVEIRA, E. N. (2001). A utilização dos laboratórios de informática do PROINFO em Dourados - MS, Dissertação de Mestrado, Universidade Federal de Santa Catarina, p 45.

OLIVEIRA, R. (1997). Informática educativa: dos planos e discursos à sala de aula. Campinas, Papirus.

PAIVIO, A. (1986). Mental representations: A dual-coding approach. New York: Oxford University Press.

PALLANT, A., TINKER, R. (2004). Reasoning with atomic-scale molecular dynamic models. Journal of Science Education and Technology, 13 (1), 51-66.

PEIRCE, C.S. (2005). Semiótica. São Paulo. Ed. Perspectiva (3a ed). 
PEIRCE, C.S. (1981). Writings of Charles S. Peirce : A Chronological Edition, Vol. 1, Peirce Edition Project (eds.), Indiana University Press, Bloomington and Indianapolis, IN.

PONDER, J. W., RICHARDS, F. M. (1987). Tinker Molecular Modeling Package.

Journal of Computerized Chemistry, 8, 1016-1024.

REGO, T.C. (1995). Vigotski: uma perspectiva histórico-cultural da educação. Petrópolis, Rio de Janeiro. Editora Vozes.

RIBEIRO, A.A., GRECA, I.M. (2003). Simulações computacionais e ferramentas de modelização em educação química: uma revisão de literatura publicada. Química Nova, 26 (4), 542-549.

RIEBER, L.R. (1996). Animation as feedback in a computer-based simulation: representation matters. Educational Technology Research and Development, 44 (1), 5-22.

ROBLYER, M. D., EDWARDS, J. (2000). Integrating Educational Technology into Teaching, 2a ed., Merryl, Upper Saddle River, New Jersey.

RODRIGUES, C. R. (2001). Processos modernos no desenvolvimento de fármacos: modelagem molecular. Cadernos Temáticos de Química Nova na Escola (Fármacos), 3, 43-49.

RODRIGUEZ, W. E. (1990). A dual approach to engineering design visualization. Engineering Design Graphics Journal 54(3): 36-43.

ROTH, W., WOSZCZYNA, C., SMITH, G. (1996). Journal of Research in Science Teaching, 33, 995.

ROZZELLE, A. A. e ROSENFELD, S. M. (1985). Stereoscopic projection in organic chemistry: bringing the gap between two and tree dimensions. Journal of Chemical Education, 62(12), 1084-1085.

RUSSEL, J., KOZMA, R. (1994). 4M:Chem-multimedia and mental models in chemistry. Journal of Chemical Education, 71, 669-670.

SALOMON, G. (1994). Interaction of media, cognition, and learning. Hillsdale, New Jersey. Lawrence Erlbaum Associates.

SANTAELLA, L. (2005). O que é semiótica. São Paulo. Ed. Brasiliense.

SAWYER, B.A. (1990). Concept learning versus problem solving: Revisited. Journal of Chemical Education, 67, 253-254. 
SCHANK, P., KOZMA, R. (2002). Learning chemistry through the use of a representation-based knowledge building environment. Journal of Computers in Mathematics and Science Teaching, 21, 253-270.

SCHUMMER, J. (2006). Gestalt switch in molecular image perception: the aesthetic origin of molecular nanotechnology in supramolecular chemistry", Foundations of Chemistry, 8, 53-72.

SEBEOK, T.A., SEBEOK, J.U. (1987). Sherlock Holmes y Charles Sanders Peirce: el método de la investigacion. Ed. Paidós, Barcelona.

SEDDON, G.M., MOORE, R.G. (1986). An unexpected effect in the use of models for teaching the visualization of rotation in molecular structures. European Journal of Science Education 8: 79-86.

SEDDON, G. M., SHUBBER, K. E., (1985). The effects of color in teaching the visualization of rotation in diagrams of three dimensional structures. British Educational Research Journal 11: 227-239.

SMITH, K., METZ, P., (1996). Evaluating student understanding of solution chemistry through microscopic representations. Journal of Chemical Education, 73, 233-235.

SMITHERS, A. (1989). Chemistry and Industry: 90-92.

SRINAVASAN, A.R. e OLSON, W.K. (1989). Viewing stereo drawings. Journal of Chemical Education. 66(8), 664-665.

STIEFF, M., WILENSKY, U. (2003). Conneted chemistry - incorporating interactive simulations into the chemistry classrooms. Journal of Science Education and Technology, 12 (3), 285-302.

STOLL, C. (1999). High Tech Heretic, Ed Anchor, New York.

SUPPES, P., SMITH, R., BEAR, M. (1975). University-Level Computer-Assisted Instruction at Stanford. Technical Report $n^{\circ} 265$, Institute for Mathematical Studies in Social Sciences, Stanford University, California.

SWAAK, J., van JOOLINGEN, W.R., de JONG, T. (1998). Supponting simulation-based learning: the effects of model progression and assignments on definitional and intuitive knowledge. Learning and Instruction, 8, 235-252.

TALLEY, L. (1973). The use oh three-dimensional visualization as a moderator in the higher cognitive learning of concepts in college level chemistry. Journal of Research in Science Education, 10(3), 263-269. 
TAN, S., TAN, L. (1997). CHEMMAT: adaptative multimedia courseware for chemistry. Journal of Science Education and Technology, 6 (1), 71-79.

TASKER, R. F., CHIA, W., BUCAT, R. B., SLEET, R., (1996). The VisChem Project - visualizing chemistry with multimedia. Chemistry in Australia, 63 (9), 395-397.

TASKER, R. F., DALTON, R. (2006). Research into practice: visualization of the molecular world using animations. Chemistry Education Research and Practice, 7 (2), 141-159.

TENG, T., TAVERAS, M. (2004). Combining live video and audio broadcasting, synchronous chat, and asynchronous open forum discussion in distance education. Journal of Educational Technology Systems, 33(2), 121-129.

TREAGUST, D.F., CHITTLEBOROUGH, G., MAMIALA, T.L. (2003). The role of submicroscopic and symbolic representations in chemical explanations. International Journal of Science Education, 25 (11), 1353-1368.

TUCKEY, H., SELVARATNAM, M., BRADLEY, J., (1991). Identification and rectification of student difficulties concerning three-dimensional structures, rotation and reflection. Journal of Chemical Education, 68(6), 460-464.

VALENTE, J. A. (2003). Educação a distância no ensino superior: soluções e flexibilizações. Interface - Comunicação, Saúde, Educação, 7 (12), 139-148.

WADDICK, J. (1994). Educ. Train. Technol. Int., 31, 98.

WELKER, J., BERARDINO, L., (2005). Blended learning: understanding the middle ground between traditional classroom and fully online instruction.

Journal of Educational Technology Systems, 34(1), 33-55.

WERTSCH, J. V. (1998). Mind as action. New York: Oxford Uni Press.

WILEY, S.E. (1990). Computer graphics and the development of visual perceptions in engeneering graphics curricula. Engineering Design Graphics Journal 54(3): 39-43.

WILLIAMSON, V. M., ABRAHAM, M. R. (1995). The effects of computer animation on the particulate mental models of college chemistry students, Journal of Research in Science Teaching, 32, 521-534.

WINN, W. (1991). Learning from maps and diagrams. Educational psychology review, 3, 211-247. 
WOLFF, R.S., YAEGER, L. (1993). Visualization of Natural Phenomena, Springer-Verlag, New York, NY.

WU, H., KRAJCIK, J.S., SOLOWAY, E. (2001). Promoting understanding of chemical representations: Students' use of visualization tool in the classroom. Journal of Research in Science Teaching, 38(7), 821-842.

WU, H. (2003). Linking the microscopic view of chemistry to real-life experiences: intertextuality in a high-school science classroom. Science Education, 87: 868-891.

XIE, Q., TINKER, R. (2004). Molecular dynamics simulations of chemical reactions for use in education. Concord, MA: Concord Consortium.

YANG, C.S., MOORE, D.M. (1996). Designing hypermedia for instruction. Journal of educational Technology Systems, 24 (1), 3-30. 
ANEXO 1 - O módulo de ensino

\section{Descrição}

O módulo de ensino utilizado neste trabalho é composto por 11 páginas em formato HTML, e está disponível no endereço eletrônico: http://www.lapeq.fe.usp.br/labdig/sequens/visualizacao

O título do módulo é "Os hidrocarbonetos e o petróleo". O conteúdo do texto trata inicialmente da composição do petróleo, passando rapidamente pela utilização dos combustíveis fósseis, e chega finalmente nas formas de representação dos hidrocarbonetos, que é a parte central e principal.

Durante o módulo são feitas nove perguntas que levam os estudantes a manipular modelos atômicos concretos e virtuais para a resolução dos problemas propostos.

As perguntas são respondidas pelos estudantes diretamente no ambiente em uma página apropriada. Desta forma as reposta ficam armazenadas em um banco de dados, uma vez que os estudantes acessaram o sistema através de senhas, o que facilita a consulta, a procura e a indexação de termos chave para um estudo sistemático das respostas.

O módulo é composto pela narrativa do texto, perguntas e objetos moleculares embutidos na página da internet. Estes objetos moleculares podem ser visualizados através do plugin Chime, amplamente utilizado no meio acadêmico e fornecido gratuitamente através da internet (http://www.mdl.com). Através deste plugin o objeto molecular pode ser manipulado tridimensionalmente pelo usuário, e muitas propriedades que dizem respeito a geometria da molécula, como as distâncias de ligação podem ser facilmente medidas.

\section{Aplicação}

Este módulo de ensino foi aplicado em um grupo de 38 estudantes da EE "Jornalista David Nasser", localizada na região do Capão Redondo em São Paulo (Capital) em novembro de 2005. Os estudantes foram trazidos para uma sala de computadores da FEUSP (LIET) em 2 dias na parte da manhã, de forma que os mesmos trabalharam na resolução do módulo por 2 horas em cada dia. As atividades do módulo foram resolvidas pelos estudantes em duplas, de forma que os mesmos pudessem discutir as questões e as formas de respondê-las. Cada dupla de estudantes utilizou um computador, sendo acompanhados pelo professor da escola, no caso, eu mesmo. Uma estudante de Licenciatura em Química da USP, Adriana da 
Silva Posso, participou da aplicação do módulo, auxiliando o professor nas dúvidas dos estudantes.

\section{Conteúdo}

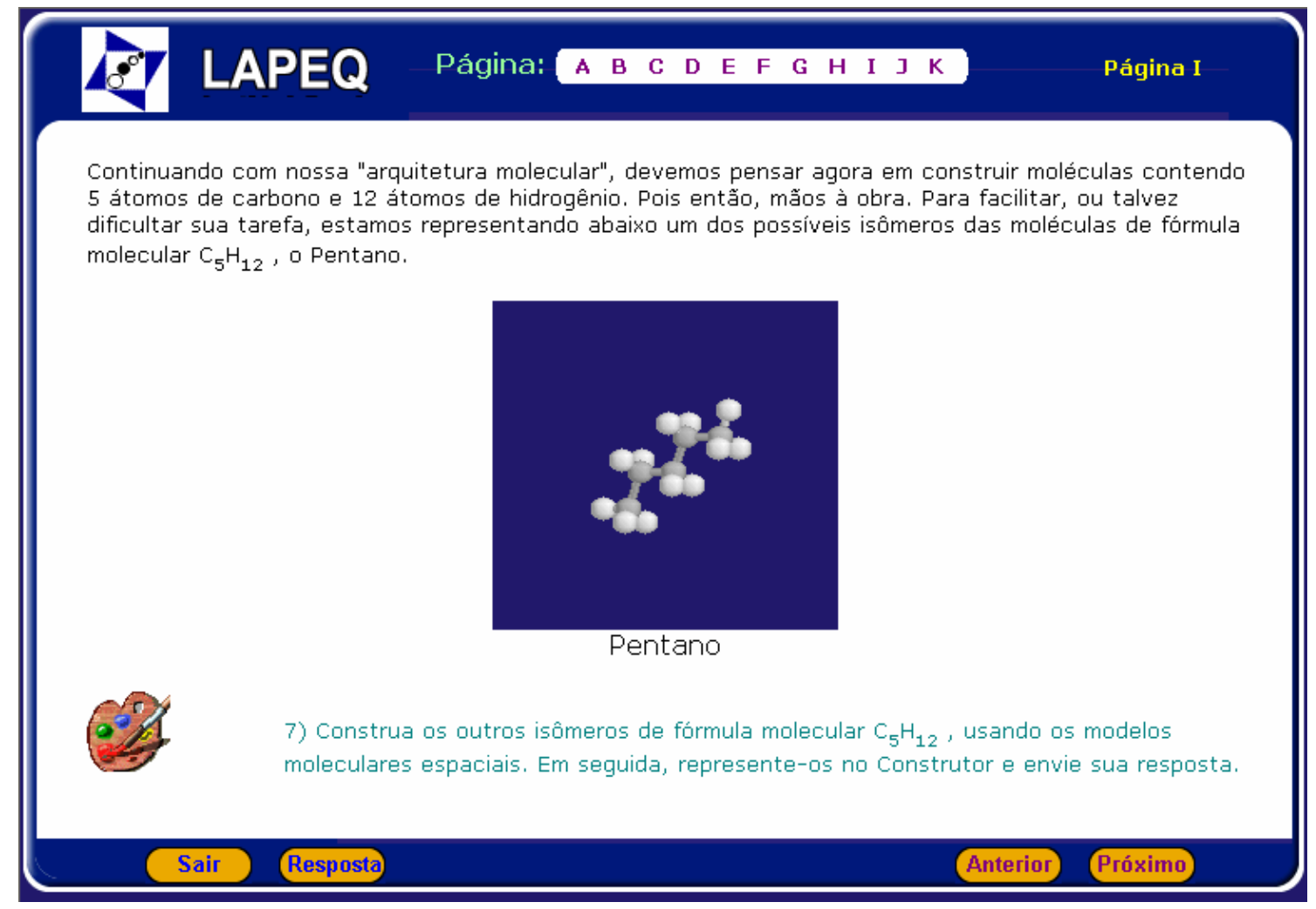

Figura XXX. Esta figura mostra uma das páginas do módulo de ensino, conforme vista pelo usuário.

Mostramos a seguir o conteúdo integral do módulo de ensino.

Página A

\section{Os Hidrocarbonetos e o Petróleo}

As moléculas orgânicas são formadas por átomos de carbono, ligados entre si e também a outros átomos. Nesta sequência de ensino, vamos nos concentrar nas moléculas formadas apenas por átomos de carbono e hidrogênio, que em função de sua composição, recebem o nome genérico de Hidrocarbonetos (hidro, relativo a hidrogênio; carboneto, relativo a carbono).

Mas por que estudar os hidrocarbonetos?

Poderíamos justificar com base em dois argumentos. Primeiro, porque os hidrocarbonetos são as moléculas orgânicas mais simples, do ponto de vista da geometria molecular. A partir do modelo tetraédrico de arranjo dos átomos ao redor do carbono, podemos construir uma série de outros modelos para explicar a geometria dos hidrocarbonetos, a natureza da ligação química entre os átomos de carbono, da ligação entre moléculas, e diversas outras propriedades moleculares.

No entanto, nosso segundo argumento é ainda mais importante quando pensamos sobre a função crucial que o Petróleo exerce sobre nossas vidas. 
O Petróleo pode ser definido como uma mistura complexa de substâncias, cujas moléculas constituintes são hidrocarbonetos. Ou seja, para entendermos de Petróleo, precisamos considerar sua origem, formação e aplicações, o que só é possível se estudarmos suas substâncias, e portanto, as moléculas que as constituem.

Assim, nossos dois argumentos justificam conjuntamente o estudo dos hidrocarbonetos. Pois, compreendendo a estrutura e as propriedades de moléculas formadas por átomos de carbono e hidrogênio, estaremos prontos para elaborar modelos explicativos sobre as substâncias que formam o Petróleo. Portanto, a partir desses modelos, caminharemos na direção de entender a origem, formação e aplicações do "óleo de pedra".
1) Vamos começar pelas aplicações. Converse com seu colega e elabore uma lista de aplicações do Petróleo. Procure formar uma lista diversificada de aplicações, que sejam representativas das mais diversas atividades humanas.

Página C

Na sua lista, certamente, deve ter constado algum combustível, como por exemplo, gás de cozinha (Gás Liqüefeito de Petróleo), gasolina, querosene, diesel e a parafina. Todas esses combustíveis são obtidos a partir do refino do petróleo, ou seja, através do processo de aquecimento e resfriamento controlado da mistura complexa de substâncias em grandes torres de destilação fracionada.

Além dos combustíveis, existem uma grande variedade de outros derivados do petróleo que são extraídos em refinarias e vendidos às indústrias petroquímicas. Essas indústrias processam os derivados e revendem para outros segmentos industriais, que por sua vez produzem cosméticos, plásticos para embalagem, tecidos para vestimenta, e uma enorme variedade de materiais de aplicação cotidiana. Portanto, o petróleo ocupa uma importante posição na economia e no bem estar das sociedades, o que nos ajuda a compreender porque a disputa pela sua posse chega a motivar guerras.

Vamos voltar a nos concentrar sobre os combustíveis que listamos acima. Sabemos que o GLP é uma gás que usamos em fogões para cozinhar. Sabemos que a gasolina, diesel e querosene são usados para movimentar motores de carros, caminhões e aviões, são líqüidos à temperatura e pressão ambientes. Já a parafina, que é menos empregada como combustível, é um sólido que usamos para fazer velas muito usadas em épocas de apagão!

2) O que explica o fato de substâncias obtidas a partir de uma mesma fonte (o petróleo) terem a mesma propriedade (reagir com oxigênio produzindo energia), mas se comportarem de forma tão diferente quanto ao estado de agregação (gás, líqüido e sólido) ?

Página D

Se você considerou em sua resposta as propriedades das moléculas que formam essas substâncias, você está a caminho de aceitar a teoria molecular como um modelo teórico robusto, a partir do qual podemos compreender as propriedades e 
transformações dos hidrocarbonetos.

Vamos considerar as aplicações do petróleo como um problema complexo para o qual iremos elaborar explicações com base na teoria molecular, começando pelas moléculas de hidrocarbonetos.

3) Vamos considerar os hidrocarbonetos formados por 1, 2, e 3 átomos de carbono. Utilizando os modelos de estrutura molecular espacial (fornecidos pelo professor), faça as possíveis representações das moléculas de hidrocarboneto contendo:

a) 1 átomo de carbono e 4 de hidrogênio;

b) 2 átomos de carbono e 6 de hidrogênio;

c) 3 átomos de carbono e 8 de hidrogênio.

Represente essas estruturas também no seu caderno e escreva suas fórmulas moleculares.

Página E

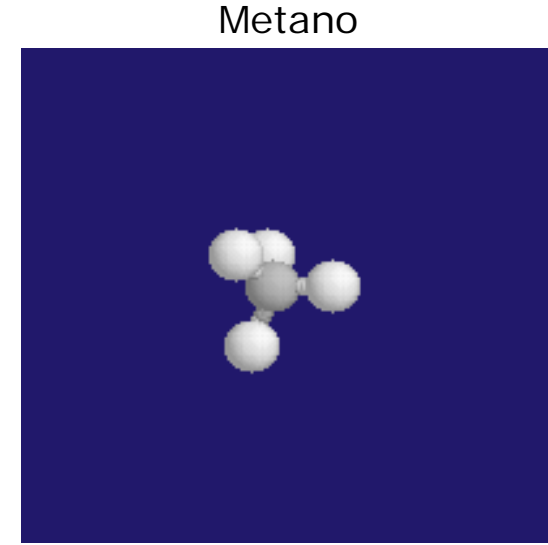

Utilizado como combustível para veículos.
Etano

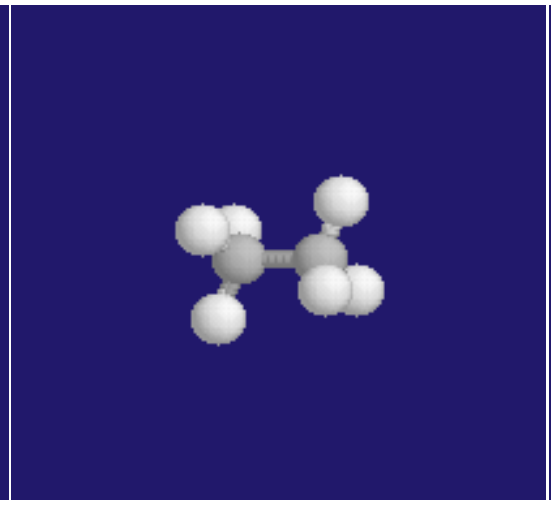

Utilizado na produção de empregada na indústria de plástico.

\section{Página F}

A forma mais comum de se representar as moléculas orgânicas no papel é através da chamada Fórmula Estrutural Plana, onde representamos as ligações químicas entre os átomos por traços. Veja como ficariam as estruturas das moléculas de metano, etano e propano nesse tipo de representação:

Metano:

Etano:

ou, na forma condensada: 
<smiles>C</smiles><smiles>CC</smiles><smiles>CC</smiles>

É importante considerar que as representações no papel são diferentes daquelas que você produziu com o modelo de estrutura molecular, e também daquelas que você visualizou na tela do computador (acima e na página anterior). No entanto, todas elas indicam as mesmas moléculas.

Página G

4) Represente o Propano no Construtor e em seu caderno utilizando para isso a Fórmula Estrutural Plana Condensada.

5) Utilizando o modelo de estrutura molecular espacial (fornecidos pelo professor), monte as possíveis estruturas para moléculas formadas por 4 átomos de carbono e 10 átomos de hidrogênio.

6) Agora com auxílio do Construtor, represente as estruturas que você obteve no Problema 5, por meio da Fórmula Estrutural Plana. Quantas estruturas vocês obteve? Qual é a fórmula molecular delas ? Construa também uma das estruturas usando a interface de simulação do Construtor (à direita da tela).

Página $H$

Você deve ter chegado a duas estruturas diferentes. Note que ambas têm a mesma fórmula molecular $\left(\mathrm{C}_{4} \mathrm{H}_{10}\right)$, mas apresentam fórmulas estruturais diferentes. Como vimos no caso dos ácidos tartáricos, estamos diante de estereoisômeros (ou simplesmente isômeros), pois ambas as moléculas têm a mesma fórmula molecular e diferem entre si apenas no arranjo tridimensional de seus átomos. 


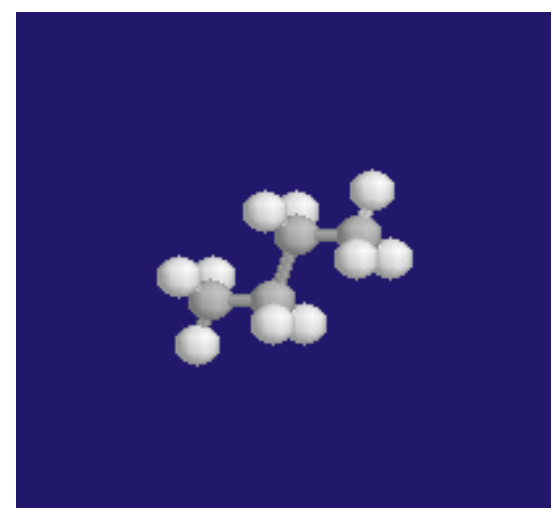

Butano

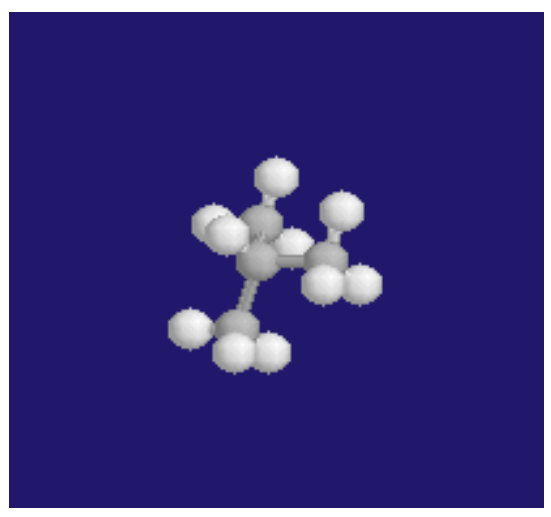

Metil-propano

Página I

Continuando com nossa "arquitetura molecular", devemos pensar agora em construir moléculas contendo 5 átomos de carbono e 12 átomos de hidrogênio. Pois então, mãos à obra. Para facilitar, ou talvez dificultar sua tarefa, estamos representando abaixo um dos possíveis isômeros das moléculas de fórmula molecular $\mathrm{C}_{5} \mathrm{H}_{12}$, o Pentano.

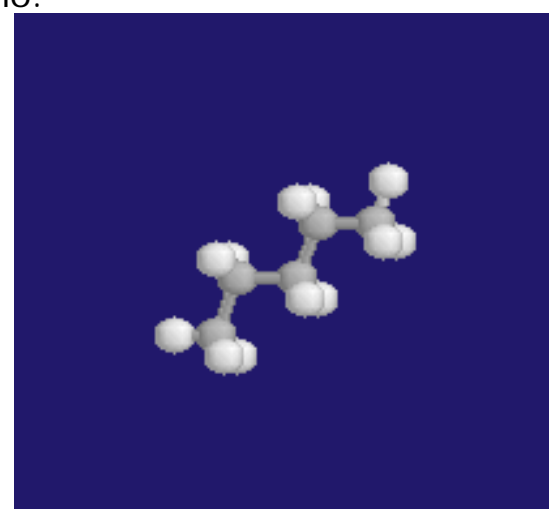

Pentano

7) Construa os outros isômeros de fórmula molecular $\mathrm{C}_{5} \mathrm{H}_{12}$, usando os modelos moleculares espaciais. Em seguida, represente-os no Construtor e envie sua resposta.

Página $J$

Poderíamos seguir adiante com nossa construção molecular, mas já está na hora de refletirmos sobre tantas regularidades, semelhanças e diferenças. A primeira regularidade que nos deparamos é com a relação entre o número de átomos de carbono e hidrogênio, o que nos leva diretamente a fórmula molecular. Observe a tabela abaixo:

\begin{tabular}{|c|c|c|}
\hline Número de C & Número de H & Diferença \\
\hline 1 & 4 & - \\
\hline 2 & 6 & 2 \\
\hline 3 & 8 & 2 \\
\hline 4 & 10 & 2 \\
\hline
\end{tabular}


A coluna da esquerda (Número de $\mathrm{C}$ ) indica o número de átomos de carbono da molécula. A coluna do meio (Número de $\mathrm{H}$ ) indica o número de átomos de hidrogênio da molécula. A coluna da direita (Diferença) foi obtida calculando-se a diferença entre o número de átomos de hidrogênio de moléculas sucessivas na escala de átomos de carbono, ou seja (6-4 / $\mathrm{C}_{2} \mathrm{H}_{6} / \mathrm{CH}_{4} ; 8-6 / \mathrm{C}_{3} \mathrm{H}_{8} / \mathrm{C}_{2} \mathrm{H}_{6} ; 10-8$ / $\left.\mathrm{C}_{4} \mathrm{H}_{10} / \mathrm{C}_{3} \mathrm{H}_{8} ; 12-10 / \mathrm{C}_{5} \mathrm{H}_{12} / \mathrm{C}_{4} \mathrm{H}_{10}\right)$.

Essa diferença, sendo constante, nos indica que estamos diante de uma série de primeira ordem (a primeira diferença é constante), que relaciona o número de átomos de hidrogênio ao número de átomos de carbono por um fator de 2 . Ou seja, sabendo-se o número de átomos de carbono $(\mathrm{N})$, é possível obtermos o número de átomos de hidrogênio, simplesmente multiplicando $\mathrm{N}$ por 2 e somando um segundo fator constante $(\mathrm{K})$.

8) Após refletir sobre esses dados e discutir com seu colega, responda: Qual é o valor de K? Quantos átomos de hidrogênio tem uma molécula hidrocarboneto (dessa classe, em que todos os átomos de carbono estão ligado a 4 átomos) contendo 6 átomos de carbono? Qual é a fórmula molecular desse hidrocarboneto?

Página $K$

A segunda regularidade sobre a qual precisamos refletir é a estrutura molecular. Observe quatro estruturas das moléculas de etano, propano, butano e pentano:
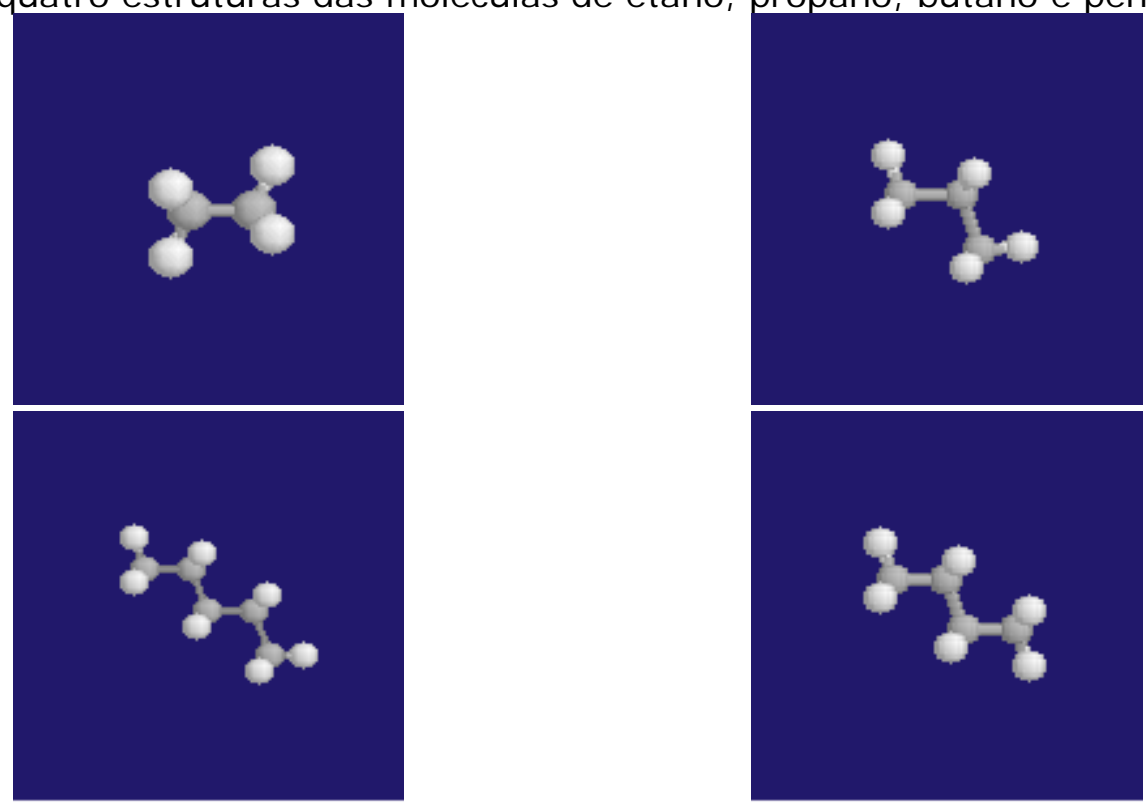

9) Comparando as estruturas, você poderia propor uma regra para obtermos cada uma das moléculas de hidrocarboneto acima (onde todos os átomos de carbono fazem quatro ligações químicas), partindo do metano $\left(\mathrm{CH}_{4}\right)$ ? Dica: lembre-se do modelo do tetraedro. 


\section{ANEXO 2 - O questionário respondido pelos estudantes}

\section{Questionário de avaliação - Laboratório de Informática da FEUSP 11 e 13 de Outubro de 2005.}

Responda as questões abaixo de forma completa. Não é necessário se identificar.

Idade:

Sexo:

1) Do ponto de vista do seu interesse, as aulas de Química em sua escola, da forma como são ministradas têm:
1: Nenhum interesse
2: Pouco interesse
3: Algum interesse
4: Muito interesse
5: Total interesse

2) Do ponto de vista do seu interesse, o tema Petróleo, de forma geral, é de:
1: Nenhum interesse
2: Pouco interesse
3: Algum interesse
4: Muito interesse
5: Total interesse

3) Do ponto de vista do seu interesse, a forma como você trabalhou nesses dois dias aqui no Laboratório de Informática lhe proporcionaram:
1: Nenhum interesse
2: Pouco interesse
3: Algum interesse
4: Muito interesse
5: Total interesse

4) Comparando suas respostas para os itens 1 e 3 , relacione abaixo os fatores que te levaram a selecionar graus de interesse distintos ou idênticos. 
5) Especificamente sobre a operação do Construtor, ou seja, a forma de utilizá-lo, você o considera:
1: Muito difícil
2: Difícil
3: Normal
4: Fácil
5: Muito fácil

6) Relacione abaixo os fatores que te levaram a selecionar o grau de dificuldade/facilidade na operação do Construtor.

7) Especificamente sobre sua capacidade de compreender as propriedades dos hidrocarbonetos, o Construtor foi:
1: Inútil
2: Pouco útil
3: Indiferente
4: Útil
5: Muito útil

8) Especificamente sobre sua capacidade de compreender as propriedades dos hidrocarbonetos, o modelo de estrutura molecular espacial fornecido pelo professor (bolas e bastões plásticos) foi:
1: Inútil
2: Pouco útil
3: Indiferente
4: Útil
5: Muito útil

9) Comparando suas respostas para os itens 7 e 8 , relacione abaixo os fatores que te levaram a selecionar graus distintos ou idênticos de utilidade.

10) Agora, faça críticas e sugestões sobre nosso trabalho nesses dois dias. 